\title{
Demonstration of the Tank Farm Washing Process and the DWPF SRAT Cycle with Sludge Batch 3 Simulant and Precipitated Pu/Gd Mixture from H-Canyon Tank 18.3
}

by

T. L. Fellinger

Westinghouse Savannah River Company

Savannah River Site

Aiken, South Carolina 29808

D. T. Hobbs

M. G. Bronikowski

B. C. Hill

J. H. Gray

This paper was prepared in connection with work done under the above contract number with the U.S. Department of Energy. By acceptance of this paper, the publisher and/or recipient acknowledges the U.S. Government's right to retain a nonexclusive, royalty-free license in and to any copyright covering this paper, along with the right to reproduce and to authorize others to reproduce all or part of the copyrighted paper. 
This document was prepared in conjunction with work accomplished under Contract No. DE-AC09-96SR18500 with the U. S. Department of Energy.

\section{DISCLAIMER}

This report was prepared as an account of work sponsored by an agency of the United States Government. Neither the United States Government nor any agency thereof, nor any of their employees, makes any warranty, express or implied, or assumes any legal liability or responsibility for the accuracy, completeness, or usefulness of any information, apparatus, product or process disclosed, or represents that its use would not infringe privately owned rights. Reference herein to any specific commercial product, process or service by trade name, trademark, manufacturer, or otherwise does not necessarily constitute or imply its endorsement, recommendation, or favoring by the United States Government or any agency thereof. The views and opinions of authors expressed herein do not necessarily state or reflect those of the United States Government or any agency thereof.

This report has been reproduced directly from the best available copy.

Available for sale to the public, in paper, from: U.S. Department of Commerce, National Technical Information Service, 5285 Port Royal Road, Springfield, VA 22161, phone: (800) 553-6847, fax: (703) 605-6900

email: orders@ntis.fedworld.gov

online ordering: http://www.ntis.gov/help/index.asp

Available electronically at http://www.osti.gov/bridge

Available for a processing fee to U.S. Department of Energy and its contractors, in paper, from: U.S. Department of Energy, Office of Scientific and Technical Information, P.O. Box 62, Oak Ridge, TN 37831-0062,

phone: (865)576-8401,

fax: (865)576-5728

email: $\underline{\text { reports@ adonis.osti.gov }}$ 
Keywords: Sludge Batch 3, Tank 18.3, Tank Farm, DWPF, SRAT

Retention: Permanent

\section{Demonstration of the Tank Farm Washing Process and the DWPF SRAT Cycle with Sludge Batch 3 Simulant and Precipitated Pu/Gd Mixture from H-Canyon Tank 18.3(U)}

Authors: T.L. Fellinger, D.T. Hobbs, M.G. Bronikowski, B.C. Hill, and J.H. Gray

Publication Date: May 8, 2002

Westinghouse Savannah River Company

Savannah River Site

Aiken, SC 29808

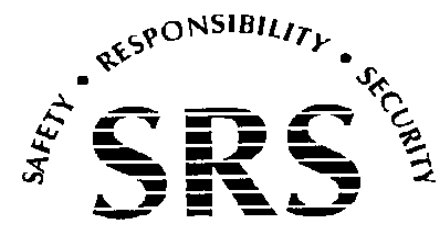

PREPARED FOR THE U.S. DEPARTMENT OF ENERGY UNDER CONTRACT NO. DE-AC09-96SR18500 
Westinghouse Savannah River Company

Savannah River Technology Center

Approval Page
WSRC-TR-2002-00208

Page 2 of 41
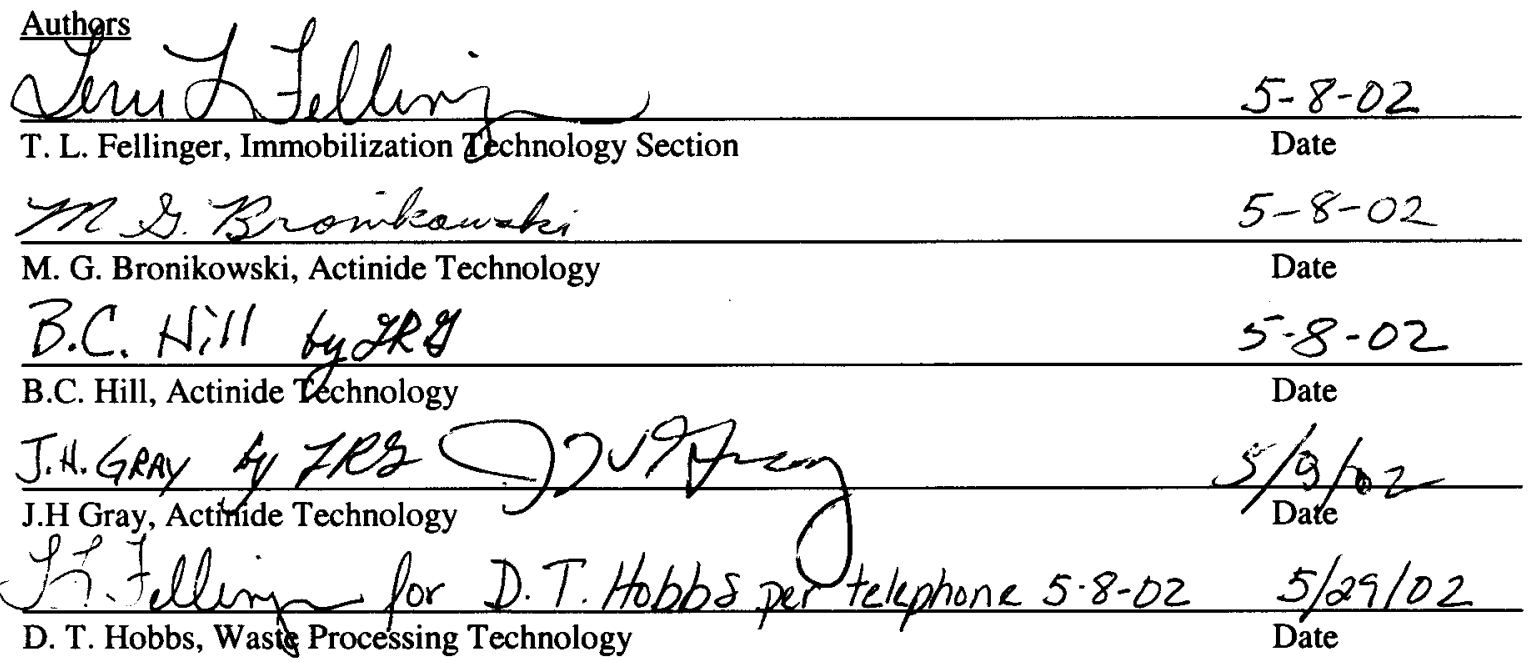

Technical Reviewer

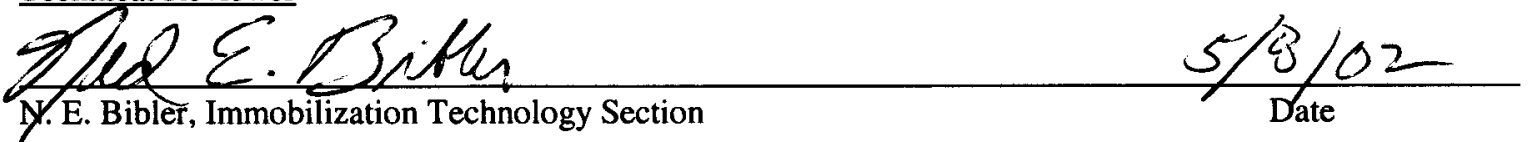

Management

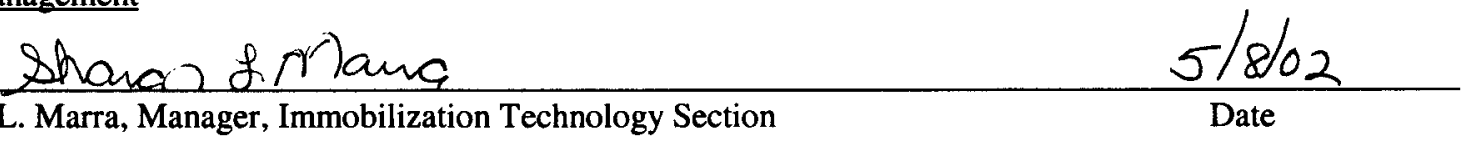

F.R. Graham
F. R. Graham, Actinide Technology
Date

\begin{tabular}{lc} 
RECur do & $5 / 8 / 02$ \\
\hline R. E. Edwards, Jr., Manager, High Level Waste Process Engineering & Date
\end{tabular}

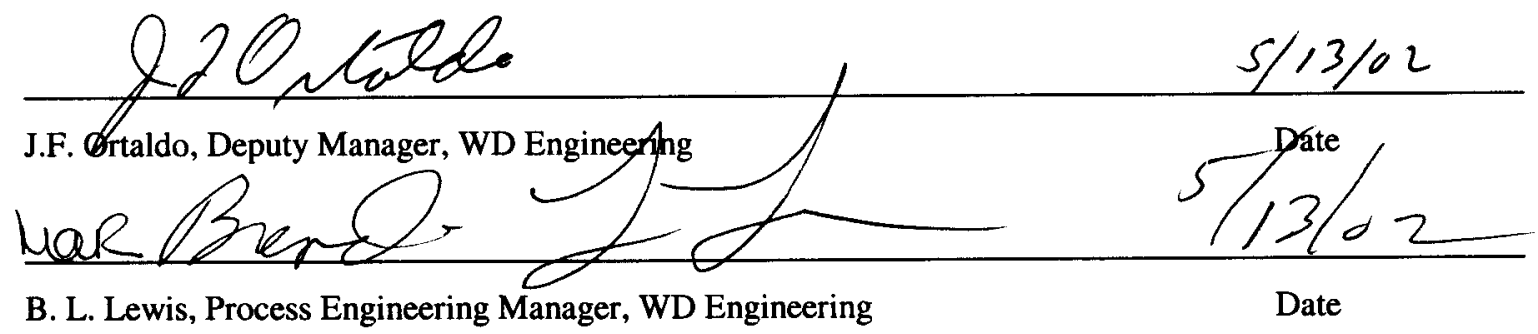

us if fend

E. J. Freed, Process Engineering Manager, CST

$5-29-02$

Date 


\section{Table of Contents}

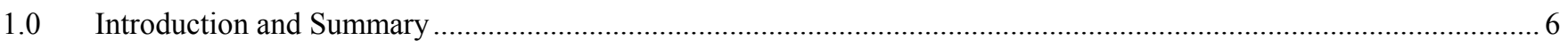

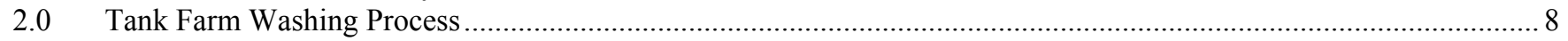

$2.1 \quad$ Selection and Adjustment of the Sludge Batch 3 Simulant................................................................................... 8

2.2 Addition of the $\mathrm{Pu} / \mathrm{Gd}$ Mixture to the Sludge Batch 3 Simulant and Washing Strategy ......................................... 9

2.3 Analytical Results of the Top Sample and Bottom Sample of the Sludge Batch 3 Simulant for the First Wash and

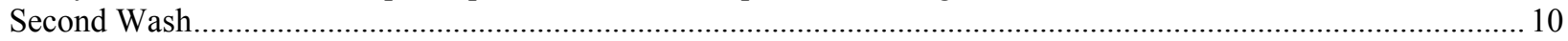

2.3.1 Total Weight Percent Solids Measurements for the Top Samples and Bottom Samples for the First and Second Washes of Sludge Batch 3 Simulant ...................................................................................................... 10

2.3.2 Comparison of the Nonradioactive Composition for Top and Bottom Samples for the First Wash and the Top and Bottom Samples for the Second Wash.....

2.3.3 ICP-MS and Counting Results for the Top and Bottom Samples for the First and Second Washes for the Sludge Batch 3 Simulant .................................................................................................................... 12

2.3.4 Comparison of the Nonradioactive Composition for the Supernate of the Top and Bottom Samples for the First Wash and the Top and Bottom Samples for the Second Wash.....

2.3.5 ICP-MS and Counting Results of the Supernate for the Top and Bottom Samples for the First and Second

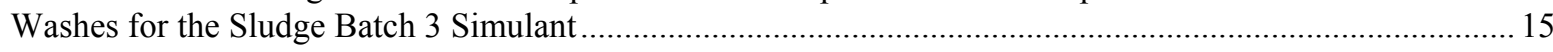

2.4 Summary of the First Wash and Second Wash Results for the Sludge Batch 3 Simulant ...................................... 16

3.0 Analytical Results of the Final Washed Sludge Batch 3 Simulant..................................................................... 17

3.1 Weight Percent Solids and Density Measurements for the Final Washed Sludge Batch 3 Simulant and Supernate.. 17

3.2 Nonradioactive Composition of the Final Washed Sludge Batch 3 Simulant........................................................ 18

3.3 Radioactive Composition of the Final Washed Sludge Batch 3 Simulant ............................................................ 18

4.0 Description of the System used to Perform the SRAT Cycle and Acid Calcualtions for the SRAT Cycle .................. 19

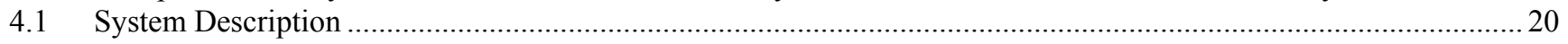

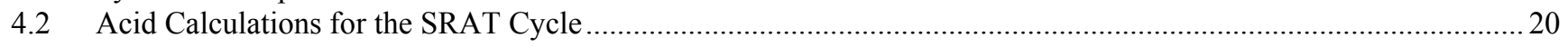

4.2.1 Titration of the Washed Sludge Slurry to Obtain the Concentration of Hydroxide..........................................20

4.2.2 TIC Concentration for the Washed Sludge Batch 3 Simulant.....................................................................2 22

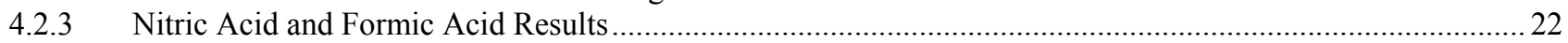

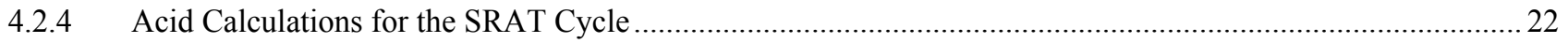

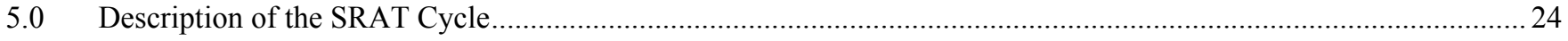

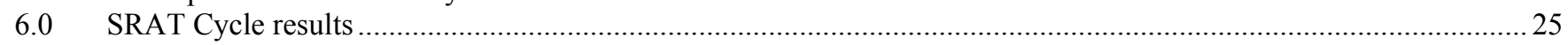

6.1 Weight Percent Solids and Density Measurements for the SRAT Product …….......................................................25

6.2 Nonradioactive Composition of the SRAT Product and the SRAT Supernate ....................................................26

6.3 Radioactive Composition for the SRAT Product and SRAT Supernate ...................................................................2 27

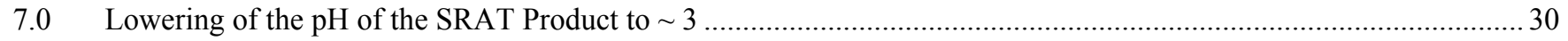

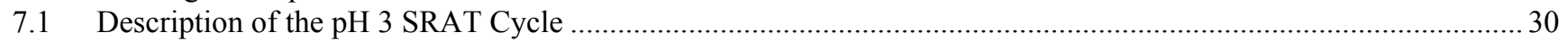

7.2 Weight Percent Solids and Density Results for the pH 3 SRAT Product .................................................................33

7.3 Nonradioactive Composition of the SRAT Product and the SRAT Supernate ..........................................................3

7.4 Radioactive Composition for the SRAT Product and SRAT Supernate ...............................................................35

7.5 Analytical Results of the Black Ring and White Solids (Coated with Sludge Slurry) Found in the SRAT Vessel.... 37

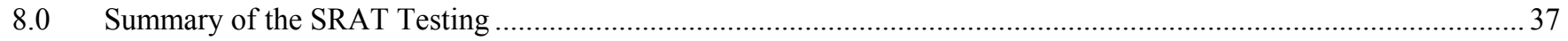

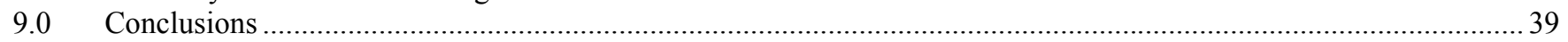

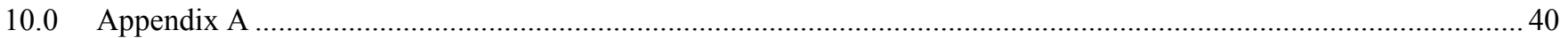

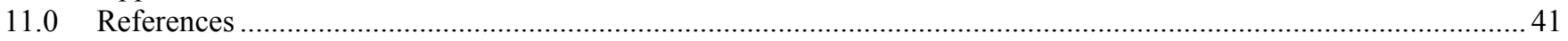




\section{List of Tables}

Table 1 - Summary of the Gd and Pu Behavior for the Tank Farm Washing Process and the SRAT Cycles. 7

Table 2 - Comparison of the Composition of the Tank 8 Simulant versus the Predicted Composition of Sludge Batch $3^{\mathrm{b}} \ldots . . .8$

Table 3 - Weight Percent Solids, Density, and Major Elements and Anions of the Supernate for the "De-Washed" Sludge Batch 3 Simulant.

Table 4 - Total Weight Percent Solids Measurements for the Top Sample and Bottom Sample for the First and Second Wash of Sludge Batch 3 Simulant......

Table 5 - Gd Concentration and Elements (excluding oxygen) with Concentrations $>0.1$ Weight Percent in the Top and Bottom Samples from the First Wash of the Sludge Batch 3 Simulant (Presented in Units of Weight Percent of Total Dried Solids)

Table 6 - Gd Concentration and Elements (excluding oxygen) with Concentrations $>0.1$ Weight Percent in the Top and Bottom Samples from the Second Wash of the Sludge Batch 3 Simulant (Presented in Units of Weight Percent of Total Dried Solids).

Table 7 - ICP-MS Results and Counting Results for the Top and Bottom Samples for the First Wash of Sludge Batch 3 ..... 12

Table 8 - ICP-MS Results and Counting Results for the Top and Bottom Samples for the Second Wash of Sludge Batch 3.13

Table 9 - ICP-ES and IC Supernate Results for Top and Bottom Samples for the First Wash of the Sludge Batch 3 Simulant

Table 10 - ICP-ES and IC Supernate Results for Top and Bottom Samples for the Second Wash of the Sludge Batch 3 Simulant ......

Table 11 - ICP-MS and Counting Results of the Supernate for the First Wash Top and Bottom Samples of the Sludge Batch

3 Simulant

Table 12 - ICP-MS and Counting Results of the Supernate for the Second Wash Top and Bottom Samples of the Sludge Batch 3 Simulant

Table 13 - Amount of Pu and Gd that Became Soluble During the Washing Process ...

Table 14 - Weight Percent Solids and Density Measurements for the Final Washed Sludge Batch 3 Simulant and Supernate

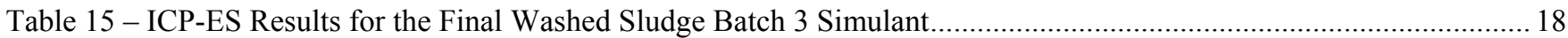

Table 16 - ICP-MS and Counting Data for the Final Washed Sludge Batch 3 Simulant .................................................... 18

Table 17 - Titration Data for Two Samples of Washed Sludge Batch 3 Simulant.............................................................2

Table 18 - Excel Spreadsheet for Determining Nitric Acid and Formic Acid Requirements for the SRAT Cycle .................23

Table 19 - Weight Percent Solids and Density Measurements for the SRAT Product.........................................................26

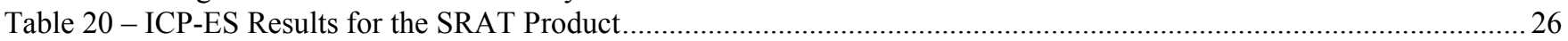

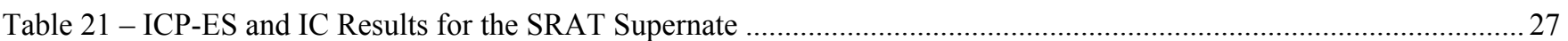

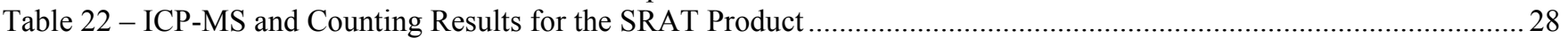

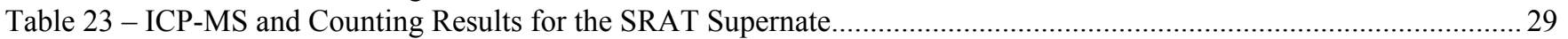

Table 24 - Amount of Al, Ca, Fe, Mg, Mn , Gd, and Pu Soluble After the SRAT Cycle ..................................................2 29

Table 25 - Excel Spreadsheet for Determining Nitric Acid and Formic Acid Requirements to Lower the pH of the SRAT

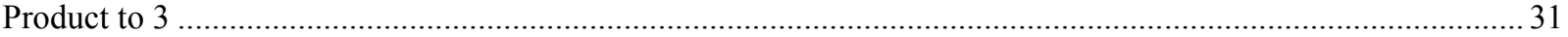

Table 26- Weight Percent Solids and Density Measurements for the SRAT Product ( $\mathrm{pH}$ of $\sim 3$ )..................................... 33

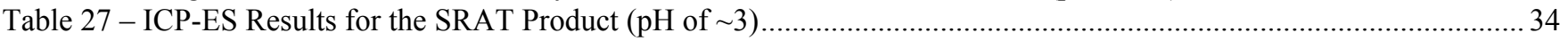

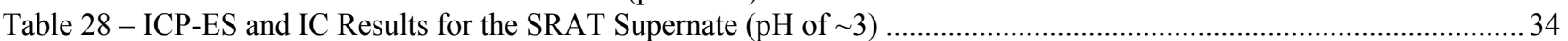

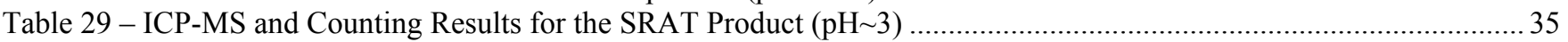

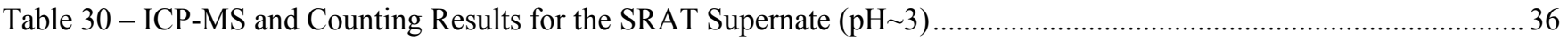

Table 31 - Amount of Al, Ca, Fe, Mg, Mn, Gd, and Pu Soluble After the SRAT Cycle (pH 3)..................................... 36

Table 32 - Fraction of Selected Elements Soluble After the First SRAT Cycle and the Second SRAT Cycle ........................38 


\section{List of Figures}

Figure 1 - Picture of the SRAT/SME Vessel in the Glove Box.

Figure 2 - Graph of the Sludge Slurry Titrations Performed for the Washed Sludge Batch 3 Simulant (pH of Sludge Slurry vs. Eq/L of Nitric Acid Added)

Figure 3 - Graph of the $\mathrm{pH}$ Taken During the SRAT Cycle Over Time ……................................................................25

Figure 4 - Graph of the $\mathrm{pH}$ Taken During the SRAT Cycle $(\mathrm{pH} \sim 3)$ Over Time …........................................................ 32

Figure 5 - Picture of the White Solids (Coated with Sludge Slurry) Found on the Bottom of the SRAT Vessel ................... 32

Figure 6 - Graph of pH Versus Elemental Fraction Dissolved During Nitric Acid Addition for Tank 51 Sludge Slurry ........ 38 


\subsection{INTRODUCTION AND SUMMARY}

The Nuclear Materials Management Division (NMMD) has proposed that certain Pu solutions stored in HCanyon be disposed to H-Tank Farm. These solutions contain significant inventories of plutonium. Prior to discharging the acidic solutions, the acid is neutralized to $>1 \mathrm{M}$ free hydroxide. The plan is to send the neutralized Pu solutions to H-Tank Farm (Tank 51) as a slurry containing precipitated Pu with sufficient Gd to prevent the possibility of criticality.

The $\mathrm{Pu} / \mathrm{Gd}$ mixture (along with the sludge slurry from Tank 7 and $\mathrm{Am} / \mathrm{Cm}$ solution) will be processed as a part of Sludge Batch 3. Sludge Batch 3 is the next sludge batch of feed for the Defense Waste Processing Facility (DWPF). In order to prepare the feed for DWPF, the sludge slurry will be washed to $\sim 0.55 \mathrm{M} \mathrm{Na}$ in the supernate. NMMD issued a Task Technical Request (TTR- NMMD-HTS-2002-010 ${ }^{1}$ ) requesting an evaluation of the processing impacts to the Tank Farm and DWPF. In response to the request in TTR- NMMD-HTS-2002-010, a matrix was developed identifying processing impacts. This report addresses the glove box work with a Sludge Batch 3 simulant and a $\mathrm{Pu} / \mathrm{Gd}$ mixture precipitated from $\mathrm{H}$-Canyon Tank $18.3^{2,3}$. The main objective of this experimental work was to determine the behavior of the Pu and Gd during the Tank Farm washing process and the SRAT process. Since this was the main objective of the experimental work, no additions of sodium oxalate, mercury, or noble metals (related to $\mathrm{H}_{2}$ production in the SRAT) were made to the Sludge Batch 3 simulant. The washing issues surrounding sodium oxalate, and the SRAT cycle issues of the $\mathrm{H}_{2}$ production (noble metals effect the $\mathrm{H}_{2}$ production during the SRAT) and the steam stripping efficiency of mercury are specific issues related to Sludge Batch 3. These issues will be investigated as a part of the Sludge Batch 3 nonradioactive work conducted at the Aiken County Technology Laboratory (ACTL) and radioactive work conducted in the Shielded Cells facility with the qualification samples. Highlights from this report are found below.

- Up to $0.95 \%$ of the Gd and $0.20 \%$ of the Pu was soluble during the glove box demonstration of the Tank Farm Washing Process. The majority of the Gd (99\%) and Pu (99.8\%) were insoluble and stayed with the sludge solids.

- The small quantities of leached plutonium during the sludge washing tests do not present a criticality safety concern and are not sufficient to adversely impact the Effluent Treatment Facility or Saltstone operations.

- No significant problems were encountered during the washing process. Based on analytical results, the $\mathrm{Pu} / \mathrm{Gd}$ mixture appeared to be uniformly distributed throughout the sludge.

- Approximately $2.64 \%$ of the Gd and $\sim 0.16 \%$ of the Pu was soluble after the glove box demonstration of the DWPF SRAT cycle. The majority of the $\mathrm{Gd}(97 \%)$ and $\mathrm{Pu}(99.8 \%)$ was insoluble and stayed with the sludge solids.

- No significant processing problems were encountered during the processing of this material through the first of two SRAT cycles.

- The nitrite was less than $102 \mathrm{ppm}$ at the end of the SRAT cycle. The DWPF requirement is $<1000 \mathrm{ppm}$ at the end of the SRAT cycle.

- Upon lowering the $\mathrm{pH}$ of the SRAT product to $\sim 3$, approximately $4.84 \%$ of the Gd and $0.15 \%$ of the Pu was soluble after the glove box demonstration of the DWPF SRAT cycle. The majority of the Gd (95\%) and Pu $(99.8 \%)$ was insoluble and stayed with the sludge solids.

- Two extra additions of antifoam were made during the 12 hour boiling period of the second SRAT cycle $(\mathrm{pH} \sim 3)$ to control foaming.

- As a well mixed slurry in the DWPF (for both SRAT scenarios studied in this experiment), there is enough Fe with the fissile $\mathrm{Pu}$ to not cause a criticality concern (i.e. Fe:Pu ratio must be greater than 160:1).

Table 1 provides a summary of the Gd and Pu behavior during the Tank Farm Process and the DWPF SRAT cycle. 
Table 1 - Summary of the Gd and Pu Behavior for the Tank Farm Washing Process and the SRAT Cycles

\begin{tabular}{|c|c|c|c|}
\hline $\begin{array}{c}\text { Top Sample - First } \\
\text { Wash }^{\mathrm{a}}(\mathrm{pH} \sim 14)\end{array}$ & Element & $\begin{array}{l}\text { \% Soluble in the } \\
\text { Supernate }\end{array}$ & $\begin{array}{l}\text { \% Insoluble in the } \\
\text { Sludge Solids }\end{array}$ \\
\hline & $\mathrm{Gd}$ & $0.70 \%$ & $99.30 \%$ \\
\hline & Pu-239 & $0.15 \%$ & $99.85 \%$ \\
\hline & $\mathrm{Pu}-240$ & $0.14 \%$ & $99.86 \%$ \\
\hline \multirow[t]{4}{*}{$\begin{array}{c}\text { Bottom Sample - First } \\
\text { Wash }^{\mathrm{a}}(\mathrm{pH} \text { 14) } \\
\end{array}$} & Element & $\begin{array}{l}\text { \% Soluble in the } \\
\text { Supernate }\end{array}$ & $\begin{array}{l}\text { \% Insoluble in the } \\
\text { Sludge Solids }\end{array}$ \\
\hline & $\mathrm{Gd}$ & $0.40 \%$ & $99.60 \%$ \\
\hline & Pu-239 & $0.19 \%$ & $99.81 \%$ \\
\hline & $\mathrm{Pu}-240$ & $0.20 \%$ & $99.80 \%$ \\
\hline \multirow[t]{3}{*}{$\begin{array}{c}\text { Top Sample - Second } \\
\text { Wash }^{\mathrm{b}}(\mathrm{pH} \text { 12.6) } \\
\end{array}$} & Element & $\begin{array}{l}\text { \% Soluble in the } \\
\text { Supernate }\end{array}$ & $\begin{array}{l}\text { \% Insoluble in the } \\
\text { Sludge Solids }\end{array}$ \\
\hline & $\mathrm{Gd}$ & $0.65 \%$ & $99.35 \%$ \\
\hline & $\mathrm{Pu}-239$ & $0.11 \%$ & $99.89 \%$ \\
\hline \multirow[t]{3}{*}{$\begin{array}{c}\text { Bottom Sample - } \\
\text { Second Wash }^{\mathrm{b}}(\mathrm{pH} \sim 12.6) \\
\end{array}$} & Element & $\begin{array}{l}\text { \% Soluble in the } \\
\text { Supernate }\end{array}$ & $\begin{array}{l}\text { \% Insoluble in the } \\
\text { Sludge Solids }\end{array}$ \\
\hline & $\mathrm{Gd}$ & $0.95 \%$ & $99.05 \%$ \\
\hline & $\mathrm{Pu}-239$ & $0.02 \%$ & $99.98 \%$ \\
\hline \multirow[t]{5}{*}{$\begin{array}{c}\text { First SRAT Cycle } \\
(\mathrm{ph} \sim 3.9) \\
\end{array}$} & Element & $\begin{array}{l}\text { \% Soluble in the } \\
\text { Supernate }\end{array}$ & $\begin{array}{l}\text { \% Insoluble in the } \\
\text { Sludge Solids }\end{array}$ \\
\hline & $\mathrm{Gd}$ & $2.64 \%$ & $97.36 \%$ \\
\hline & $\mathrm{Pu}-239$ & $0.06 \%$ & $99.94 \%$ \\
\hline & $\mathrm{Pu}-240$ & $0.06 \%$ & $99.94 \%$ \\
\hline & $\mathrm{Pu}-242^{\mathrm{e}}$ & $0.17 \%$ & $99.83 \%$ \\
\hline \multirow[t]{4}{*}{$\begin{array}{c}\text { Second SRAT Cycle } \\
(p h \sim 3.2)\end{array}$} & Element & $\begin{array}{l}\text { \% Soluble in the } \\
\text { Supernate }\end{array}$ & $\begin{array}{l}\text { \% Insoluble in the } \\
\text { Sludge Solids } \\
\end{array}$ \\
\hline & $\mathrm{Gd}$ & $4.84 \%$ & $95.16 \%$ \\
\hline & $\mathrm{Pu}-239$ & $0.15 \%$ & $99.85 \%$ \\
\hline & $\mathrm{Pu}-240$ & $0.13 \%$ & $99.87 \%$ \\
\hline
\end{tabular}

${ }^{\mathrm{a}}$ Assumptions used for calculation: Total volume of $1561 \mathrm{~mL}, 14.75 \mathrm{wt} . \%$ total solids, slurry density $1.12 \mathrm{~g} / \mathrm{mL}, 9.83 \mathrm{wt} . \%$ dissolved solids, and $1.08 \mathrm{~g} / \mathrm{mL}$ supernate density.

${ }^{\mathrm{b}}$ Assumptions used for calculation: Total volume of $1735 \mathrm{~mL}, 7.23 \mathrm{wt} . \%$ total solids, slurry density $1.05 \mathrm{~g} / \mathrm{mL}, 3.66 \mathrm{wt}$. \% dissolved solids, and $1.03 \mathrm{~g} / \mathrm{mL}$ supernate density.

${ }^{c}$ Assumptions: Total volume of $300 \mathrm{~mL}, 17.5 \mathrm{wt} . \%$ total solids, slurry density $1.155 \mathrm{~g} / \mathrm{mL}, 7.89 \mathrm{wt} . \%$ dissolved solids, and $1.07 \mathrm{~g} / \mathrm{mL}$ supernate density.

${ }^{\mathrm{d}}$ Assumptions: Total volume of $245 \mathrm{~mL}, 17.3 \mathrm{wt} . \%$ total solids, slurry density $1.16 \mathrm{~g} / \mathrm{mL}, 7.67 \mathrm{wt} . \%$ dissolved solids, and $1.07 \mathrm{~g} / \mathrm{mL}$ supernate density.

${ }^{\mathrm{e}}$ Due to the low concentrations of $\mathrm{Pu}$, this difference is attributed to analytical error.

Outside of the sodium oxalate, noble metals, and mercury issues identified as specific issues related to Sludge Batch 3, other issues concerning Sludge Batch 3 were identified when performing this work. They are listed below and should be considered prior to performing the nonradioactive work and radioactive work for Sludge Batch 3.

1. Resolve the issues surrounding the method of determining TIC/TOC for the sludge slurries that have coal added to them. The TIC concentration is an input for the acid calculations for the SRAT cycle. The TOC concentration will affect the final redox of the melter $\left(\mathrm{Fe}^{2+} / \mathrm{Fe}^{\text {tot }}\right)$ which directly affects the amount of formic acid added during the SRAT cycle.

2. Revise the spreadsheet for the SRAT acid calculations to incorporate sludge slurries that have coal/carbon in them.

3. Resolve the differences observed between the Gd concentrations obtained from the radioactive ICPES versus the concentrations obtained from the radioactive ICP-MS. The Gd values from the ICP-ES appeared to be biased high by $20 \%$. 
4. Determine if coal/carbon ring forms above the sludge slurry for the nonradioactive and radioactive Sludge Batch 3 testing. If coal/carbon remains behind in the vessel, it could impact the ability to reliably predict the redox of the glass.

5. Determine if sand is observed on the bottom of the SRAT vessel for the nonradioactive scoping SRAT runs.

6. Verify the Fe to fissile material in the washed sludge slurry and the SRAT product is greater than 160:1 for the radioactive testing in the Shielded Cells.

7. Analyze the supernate at the end of the SRAT cycle to determine what species have dissolve from the sludge solids for the radioactive testing in the Shielded Cells.

\subsection{TANK FARM WASHING PROCESS}

As noted in Section 1.0, the objective of the Tank Farm washing process was to study the behavior of the Pu/Gd during this process. Since that was the main objective of the washing process, no sodium oxalate was added to the Sludge Batch 3 simulant. The following sections below provide a description of the Tank Farm washing process that was completed in a glove box at SRTC with a nonradioactive Sludge Batch 3 simulant and a Pu/Gd mixture precipitated from a sample of acidic solution from H-Canyon Tank 18.3. Also presented in the following sections are the analytical data obtained during the washing process.

\subsection{Selection and Adjustment of the Sludge Batch 3 Simulant}

Based on the predicted composition of Sludge Batch $3^{5}$, Tank 8 (nonradioactive) sludge slurry simulant was selected for the glove box testing. This simulant was selected because the composition closely matched that of Sludge Batch 3 of the available nonradioactive sludge slurries on hand. Table 2 presents the composition of the Tank 8 simulant compared to the predicted Sludge Batch 3 composition.

Table 2 - Comparison of the Composition of the Tank 8 Simulant versus the Predicted Composition of Sludge Batch $3^{\mathrm{b}}$

\begin{tabular}{|c|c|c|}
\hline Element & Wt. \% for Tank 8 Simulant & \\
\hline $\mathrm{Al}$ & 9.30 & Wt. \% for Sludge Batch 3 $^{\mathbf{b}}$ \\
\hline $\mathrm{Ba}$ & 0.20 & 9.89 \\
\hline $\mathrm{Ca}$ & 2.22 & 0.23 \\
\hline $\mathrm{Cr}$ & 0.22 & 2.67 \\
\hline $\mathrm{Cu}$ & 0.13 & 0.26 \\
\hline $\mathrm{Fe}$ & 26.2 & 0.16 \\
\hline $\mathrm{K}$ & 0.01 & 29.1 \\
\hline $\mathrm{Mg}$ & 0.12 & 0.37 \\
\hline $\mathrm{Mn}$ & 2.55 & 0.11 \\
\hline $\mathrm{Na}$ & 6.0 & 5.74 \\
\hline $\mathrm{Ni}$ & 2.81 & 8.15 \\
\hline $\mathrm{Pb}$ & 0.10 & 1.31 \\
\hline $\mathrm{Si}$ & 0.89 & 0.29 \\
\hline $\mathrm{Sr}$ & 0.08 & 1.01 \\
\hline $\mathrm{Zn}$ & 0.22 & - \\
\hline $\mathrm{Zr}$ & 0.37 & 0.34 \\
\hline $\mathrm{D}$ & & 0.59 \\
\hline
\end{tabular}

${ }^{a}$ Per E-mail from D.C. Koopman. Sample was dried at $110^{\circ} \mathrm{C}$ overnight and then dissolved.

${ }^{\mathrm{b}}$ Reference WSRC-TR-2002-00145, "An Assessment of the Impacts of Adding Pu/Gd and Am/Cm Waste Streams to Sludge Batch 3 (SB3) on DWPF $\mathrm{H}_{2}$ Generation rates and Glass Properties (U) ${ }^{5}$.

To match the starting sodium molarity of Sludge Batch 3 in Tank 51, the Tank 8 simulant was "dewashed" from $\sim 0.57 \mathrm{M} \mathrm{Na}$ to $\sim 5 \mathrm{M} \mathrm{Na}$ concentration in the supernate by adding $\mathrm{Na}_{2} \mathrm{CO}_{3}, \mathrm{NaCl}$, $\mathrm{NaOH}, \mathrm{NaNO}_{2}, \mathrm{NaNO}_{3}$, and $\mathrm{Na}_{2} \mathrm{SO}_{4}$. Representative amounts of sand (20-28 mesh Tyler screen or 600 to 800 micron) and coal (20-28 mesh Tyler screen or 600-800 micron) were added to the "de-washed" Tank 8 simulant (Tank 8 simulant will be referred to as Sludge Batch 3 simulant). Presented below in Table 3 are the "de-washed" weight percent solids, density, and the major elements and anions detected 
in the supernate of the Sludge Batch 3 simulant. The standard deviation and the percent relative standard deviation are presented below the value in parentheses.

Table 3 - Weight Percent Solids, Density, and Major Elements and Anions of the Supernate for the "DeWashed" Sludge Batch 3 Simulant

\begin{tabular}{|c|c|}
\hline Weight Percent Solids of the Sludge Batch 3 Simulant $^{\mathbf{a}}$ & $\begin{array}{c}32.6 \text { wt. } \% \\
( \pm 1.1 \mathrm{E} 00,3.3 \mathrm{E} 00) \\
\end{array}$ \\
\hline Weight Percent Solids of the Sludge Batch 3 Supernate $^{\mathrm{a}, \mathrm{c}}$ & $\begin{array}{c}23.7 \text { wt. } \% \\
( \pm 7.0 \mathrm{E}-01,3.1 \mathrm{E} 00)\end{array}$ \\
\hline Density of the Sludge Batch 3 Simulant ${ }^{b}$ & $\begin{array}{c}1.29 \mathrm{~g} / \mathrm{mL} \\
( \pm 4.0 \mathrm{E}-03,3.1 \mathrm{E}-01)\end{array}$ \\
\hline Density of the Sludge Batch 3 Supernate ${ }^{b, c}$ & $\begin{array}{c}1.20 \mathrm{~g} / \mathrm{mL} \\
( \pm 3.0 \mathrm{E}-03,2.9 \mathrm{E}-01) \\
\end{array}$ \\
\hline $\mathbf{A l}^{\mathbf{c}}$ & $\begin{array}{c}\text { 6.85E03 } \mu \mathrm{g} / \mathrm{mL} \text { of Supernate } \\
( \pm 1.1 \mathrm{E} 02,1.7 \mathrm{E} 00)\end{array}$ \\
\hline $\mathbf{C a}^{\mathrm{c}}$ & $\begin{array}{c}\text { 5.98E00 } \mu \mathrm{g} / \mathrm{mL} \text { of Supernate } \\
( \pm 4.0 \mathrm{E}-02,6.7 \mathrm{E}-01)\end{array}$ \\
\hline $\mathrm{Cr}^{\mathrm{c}}$ & $\begin{array}{c}\text { 1.29E00 } \mu \mathrm{g} / \mathrm{mL} \text { of Supernate } \\
( \pm 1.0 \mathrm{E}-02,7.8 \mathrm{E}-01)\end{array}$ \\
\hline $\mathbf{K}^{\mathbf{c}}$ & $\begin{array}{c}\text { 1.72E02 } \mu \mathrm{g} / \mathrm{mL} \text { of Supernate } \\
( \pm 1.5 \mathrm{E} 00,8.9 \mathrm{E}-01)\end{array}$ \\
\hline $\mathbf{N a}^{\mathbf{c}}$ & $\begin{array}{c}\text { 1.07E05 } \mu \mathrm{g} / \mathrm{mL} \text { of Supernate } \\
( \pm 5.8 \mathrm{E} 02,5.4 \mathrm{E}-01)\end{array}$ \\
\hline Chloride $^{\mathrm{c}}$ & $\begin{array}{c}\text { 1.07E04 } \mu \mathrm{g} / \mathrm{mL} \text { of Supernate } \\
( \pm 1.5 \mathrm{E} 02,1.4 \mathrm{E} 00)\end{array}$ \\
\hline Nitrite $^{\mathrm{c}}$ & $\begin{array}{c}9.26 \mathrm{E} 04 \mu \mathrm{g} / \mathrm{mL} \text { of Supernate } \\
( \pm 6.7 \mathrm{E} 02,7.2 \mathrm{E}-01)\end{array}$ \\
\hline Nitrate $^{c}$ & $\begin{array}{c}\text { 1.54E04 } \mu \mathrm{g} / \mathrm{mL} \text { of Supernate } \\
( \pm 8.4 \mathrm{E} 02,5.5 \mathrm{E} 00)\end{array}$ \\
\hline Sulfate $^{c}$ & $\begin{array}{c}\text { 5.74E } 03 \mu \mathrm{g} / \mathrm{mL} \text { of Supernate } \\
( \pm 6.5 \mathrm{E} 01,1.1 \mathrm{E} 00)\end{array}$ \\
\hline
\end{tabular}

\subsection{Addition of the Pu/Gd Mixture to the Sludge Batch 3 Simulant and Washing Strategy}

To a calibrated washing vessel, $575 \mathrm{~mL}$ of mixed "de-washed" Sludge Batch 3 simulant was added and transferred into a glove box. Based on the expected final washed volume of the sludge slurry (calculated from an Excel spreadsheet), a calculation was performed to determine how much $\mathrm{Pu} / \mathrm{Gd}$ mixture had to be added to represent $170 \mathrm{~kg}$ of $\mathrm{Pu}$ in Tank 51. It was determined that $63.3 \mathrm{~g}$ of the $\mathrm{Pu} / \mathrm{Gd}$ mixture had to be added to the "de-washed" Sludge Batch 3 simulant. The Pu/Gd mixture that was added to the Sludge Batch 3 simulant had been precipitated from a sample of Tank 18.3 from H-Canyon ${ }^{4}$.

After the addition of 63.4 grams (target $63.3 \mathrm{~g}$ actually added $63.4 \mathrm{~g}$ ) of the $\mathrm{Pu} / \mathrm{Gd}$ mixture, the Sludge Batch 3 simulant was thoroughly mixed by capping and shaking the contents of the washing vessel by hand. The vessel was then uncapped and the first addition of inhibited water $(1000 \mathrm{~mL}$ of $0.015 \mathrm{M} \mathrm{NaOH}$ and $0.015 \mathrm{M} \mathrm{NaNO}_{2}$ solution) was added. The cap for the washing vessel was replaced and the contents were thoroughly mixed by hand. The washing vessel was then placed on a stir plate and the stir plate was turned on to mix the contents of the washing vessel for sampling (A magnetic stir bar had been placed in the vessel after the "de-washed" Sludge Batch 3 had been added to the washing vessel.). The contents were allowed to stir for approximately 10 minutes prior to taking sludge slurry samples from the top and bottom of the washing vessel. Top and bottom samples were taken for each wash to show that there were no differences in the composition (i.e. $\mathrm{Pu} / \mathrm{Gd}$ segregates or settles). After taking the samples, the stir plate was turned off and the cap was placed back on the washing vessel to prevent evaporation. The Sludge Batch 3 simulant was then allowed to sit undisturbed for $\sim 5$ days so the sludge could settle prior to decant. 
At the end of 5 days, the sludge slurry in the washing vessel had separated into two layers. One being a clear supernate layer and the other being a sludge layer. Approximately $1000 \mathrm{~mL}$ of the clear supernate was removed during the first decant. After the decant was complete, the second addition of inhibited water (1200 $\mathrm{mL}$ of $0.015 \mathrm{M} \mathrm{NaOH}$ and $0.015 \mathrm{M} \mathrm{NaNO}_{2}$ solution) was added and the same sampling technique (top and bottom samples) was used as in the first wash. At the end of the 5 day settling period, approximately $1200 \mathrm{~mL}$ of clear supernate was removed. Upon receiving the weight percent solids results (13.5 wt.\%), another $85 \mathrm{~mL}$ of supernate was removed to target a higher weight percent solids value (15.3 wt.\%) for the DWPF SRAT cycle.

\subsection{Analytical Results of the Top Sample and Bottom Sample of the Sludge Batch 3 Simulant for the First Wash and Second Wash}

Provided below are the results of the analyses for the top sample and bottom sample from the first wash and second wash of the Sludge Batch 3 simulant. The samples were allowed the same contact time of 5 days with the inhibited water, as in the washing vessel, prior to analysis.

\subsubsection{Total Weight Percent Solids Measurements for the Top Samples and Bottom Samples for the First and Second Washes of Sludge Batch 3 Simulant}

Triplicate measurements of the total weight percent solids for the sludge slurry were completed. Mixed portions of a sample of sludge slurry were pipetted into three labeled, pre-weighed vessels. After the addition of the mixed sludge slurry, the vessels were weighed and placed into a drying oven at $110^{\circ} \mathrm{C}$ overnight. The samples were removed from the oven and were allowed to cool for $\sim 5$ minutes before they were weighed. The averages of the calculated results of the weight percent solids for the sludge slurry are presented in column two of Table 4. The standard deviations (Std. Dev.) and the percent relative standard deviations (\% RSD) for the data are presented in column three and column four respectively of Table 4.

Table 4 - Total Weight Percent Solids Measurements for the Top Sample and Bottom Sample for the First and Second Wash of Sludge Batch 3 Simulant

\begin{tabular}{|c|c|c|c|}
\hline Sample ID & $\begin{array}{c}\text { Total Weight Percent } \\
\text { Solids (wt.\%) }\end{array}$ & Std. Dev. & \% RSD \\
\hline Top Sample - First Wash & 14.75 & $\pm 8.3 \mathrm{E}-02$ & $5.6 \mathrm{E}-01$ \\
\hline Bottom Sample - First Wash & 14.76 & $\pm 1.4 \mathrm{E}-01$ & $9.6 \mathrm{E}-01$ \\
\hline Top Sample - Second Wash & 7.28 & $\pm 8.0 \mathrm{E}-02$ & $1.1 \mathrm{E} 00$ \\
\hline Bottom Sample - Second Wash & 7.17 & $\pm 9.9 \mathrm{E}-02$ & $1.4 \mathrm{E} 00$ \\
\hline
\end{tabular}

\subsubsection{Comparison of the Nonradioactive Composition for Top and Bottom Samples for the First Wash and the Top and Bottom Samples for the Second Wash}

For each sample, triplicate portions of mixed sludge slurry were taken and dried overnight in a drying oven at $115^{\circ} \mathrm{C}$. These samples of the dried sludge slurry were dissolved by the Aqua Regia methods ${ }^{6}$ along with a glass standard (ARG) to check the dissolutions and the analytical methods. After performing the dissolution methods on the sludge slurry, the samples were sent to Analytical Development Section (ADS) Sample Receiving for analyses to be performed by ADS. The dissolution results of the standard glass for the nonradioactive elemental composition were in good agreement with the known values indicating that the analytical methods were complete and performed correctly. Table 5 presents the Gd concentration and elements (excluding oxygen) with concentrations $>0.1$ weight percent for the top and bottom samples for the first wash of the Sludge Batch 3 simulant obtained from the Inductively Coupled Plasma- Emission Spectroscopy (ICP-ES). Table 5 also presents the standard deviation and the percent relative standard deviation in parentheses next to the weight percent value. Table 6 presents the Gd concentration and elements (excluding oxygen) with concentrations $>0.1$ weight percent for the top and bottom samples for the second wash of the Sludge Batch 3 simulant obtained from the Inductively Coupled Plasma- Emission 
Spectroscopy (ICP-ES). Table 6 also presents the standard deviation and the percent relative standard deviation in parentheses next to the weight percent value.

Table 5 - Gd Concentration and Elements (excluding oxygen) with Concentrations $>0.1$ Weight Percent in the Top and Bottom Samples from the First Wash of the Sludge Batch 3 Simulant (Presented in Units of Weight Percent of Total Dried Solids)

\begin{tabular}{|c|c|c|}
\hline Element & $\begin{array}{c}\text { Top Sample }- \text { First Wash } \\
\text { Wt.\% (Std. Dev., \%RSD) }\end{array}$ & $\begin{array}{c}\text { Bottom Sample }- \text { First Wash } \\
\text { Wt.\% (Std. Dev., \%RSD) }\end{array}$ \\
\hline $\mathrm{Al}$ & $4.40 \mathrm{E} 00( \pm 1.1 \mathrm{E}-01,2.6 \mathrm{E} 00)$ & $4.40 \mathrm{E} 00( \pm 5.2 \mathrm{E}-02,1.2 \mathrm{E} 00)$ \\
\hline $\mathrm{Ba}$ & $1.16 \mathrm{E}-01( \pm 3.2 \mathrm{E}-03,2.8 \mathrm{E} 00)$ & $1.15 \mathrm{E}-01( \pm 4.6 \mathrm{E}-03,4.0 \mathrm{E} 00)$ \\
\hline $\mathrm{Ca}$ & $1.01 \mathrm{E} 00( \pm 2.1 \mathrm{E}-02,2.1 \mathrm{E} 00)$ & $1.01 \mathrm{E} 00( \pm 7.1 \mathrm{E}-03,7.0 \mathrm{E}-01)$ \\
\hline $\mathrm{Fe}$ & $1.16 \mathrm{E} 01( \pm 2.5 \mathrm{E}-01,2.1 \mathrm{E} 00)$ & $1.17 \mathrm{E} 01( \pm 9.8 \mathrm{E}-02,8.4 \mathrm{E}-01)$ \\
\hline $\mathrm{Gd}$ & $3.87 \mathrm{E}-02( \pm 6.8 \mathrm{E}-04,1.8 \mathrm{E} 00)$ & $3.85 \mathrm{E}-02( \pm 5.8 \mathrm{E}-04,1.5 \mathrm{E} 00)$ \\
\hline $\mathrm{Mn}$ & $1.33 \mathrm{E} 00( \pm 3.9 \mathrm{E}-02,2.9 \mathrm{E} 00)$ & $1.33 \mathrm{E} 00( \pm 7.6 \mathrm{E}-02,5.7 \mathrm{E} 00)$ \\
\hline $\mathrm{Na}$ & $2.48 \mathrm{E} 01( \pm 6.5 \mathrm{E}-01,2.6 \mathrm{E} 00)$ & $2.47 \mathrm{E} 01( \pm 2.1 \mathrm{E}-01,8.7 \mathrm{E}-01)$ \\
\hline $\mathrm{Ni}$ & $1.32 \mathrm{E} 00( \pm 2.9 \mathrm{E}-02,2.2 \mathrm{E} 00)$ & $1.32 \mathrm{E} 00( \pm 1.1 \mathrm{E}-02,8.3 \mathrm{E}-01)$ \\
\hline $\mathrm{Si}$ & $6.0 \mathrm{E}-01( \pm 1.9 \mathrm{E}-03,3.1 \mathrm{E}-01)$ & $6.5 \mathrm{E}-01( \pm 5.3 \mathrm{E}-02,8.2 \mathrm{E} 00)$ \\
\hline $\mathrm{U}$ & $1.49 \mathrm{E}-01( \pm 1.8 \mathrm{E}-03,1.2 \mathrm{E} 00)$ & $1.51 \mathrm{E}-01( \pm 2.6 \mathrm{E}-03,1.7 \mathrm{E} 00)$ \\
\hline $\mathrm{Zn}$ & $1.22 \mathrm{E}-01( \pm 2.1 \mathrm{E}-03,1.7 \mathrm{E} 00)$ & $1.22 \mathrm{E}-01( \pm 1.7 \mathrm{E}-03,1.4 \mathrm{E} 00)$ \\
\hline
\end{tabular}

${ }^{a} \mathrm{Si}$ was added to the table because it exceeded the $0.1 \mathrm{wt} . \%$ criteria. However, this number should not be used because it is known that this dissolution method does not dissolve all of the Si.

${ }^{\mathrm{b}}$ Results are determined by ICP-ES and are the averages of results of three samples of dissolved dried slurry. The standard deviation and the percent relative standard deviation are presented in parentheses next to each value.

Table 6 - Gd Concentration and Elements (excluding oxygen) with Concentrations $>0.1$ Weight Percent in the Top and Bottom Samples from the Second Wash of the Sludge Batch 3 Simulant (Presented in Units of Weight Percent of Total Dried Solids)

\begin{tabular}{|c|c|c|}
\hline Element & $\begin{array}{c}\text { Top Sample - Second Wash } \\
\text { Wt.\% (Std. Dev., \%RSD) }\end{array}$ & $\begin{array}{c}\text { Bottom Sample - Second Wash } \\
\text { Wt.\% (Std. Dev., \%RSD) }\end{array}$ \\
\hline $\mathrm{Al}$ & $5.60 \mathrm{E} 00( \pm 5.7 \mathrm{E}-02,1.0 \mathrm{E} 00)$ & $5.70 \mathrm{E} 00( \pm 9.8 \mathrm{E}-02,1.7 \mathrm{E} 00)$ \\
\hline $\mathrm{Ba}$ & $2.02 \mathrm{E}-01( \pm 6.0 \mathrm{E}-03,3.0 \mathrm{E} 00)$ & $2.10 \mathrm{E}-01( \pm 2.7 \mathrm{E}-03,1.3 \mathrm{E} 01)$ \\
\hline $\mathrm{Ca}$ & $1.81 \mathrm{E} 00( \pm 3.2 \mathrm{E}-02,1.7 \mathrm{E} 00)$ & $1.85 \mathrm{E} 00( \pm 3.8 \mathrm{E}-02,2.1 \mathrm{E} 00)$ \\
\hline $\mathrm{Cr}$ & $1.27 \mathrm{E}-01( \pm 3.0 \mathrm{E}-03,2.4 \mathrm{E} 00)$ & $9.08 \mathrm{E}-02( \pm 2.6 \mathrm{E}-03,2.9 \mathrm{E} 00)$ \\
\hline $\mathrm{Cu}$ & $1.07 \mathrm{E}-01( \pm 1.6 \mathrm{E}-03,1.5 \mathrm{E} 00)$ & $1.10 \mathrm{E}-01(1.9 \mathrm{E}-03,1.7 \mathrm{E} 00)$ \\
\hline $\mathrm{Fe}$ & $2.13 \mathrm{E} 01( \pm 2.7 \mathrm{E}-01,1.2 \mathrm{E} 00)$ & $2.16 \mathrm{E} 01( \pm 5.3 \mathrm{E}-01,2.4 \mathrm{E} 00)$ \\
\hline $\mathrm{Gd}$ & $7.32 \mathrm{E}-02( \pm 3.7 \mathrm{E}-03,5.1 \mathrm{E} 00)$ & $7.08 \mathrm{E}-02( \pm 1.5 \mathrm{E}-03,2.1 \mathrm{E} 00)$ \\
\hline $\mathrm{Mg}$ & $1.12 \mathrm{E}-01( \pm 4.9 \mathrm{E}-04,4.4 \mathrm{E}-01)$ & $1.15 \mathrm{E}-01( \pm 5.30 \mathrm{E}-04,4.6 \mathrm{E}-01)$ \\
\hline $\mathrm{Mn}$ & $2.29 \mathrm{E} 00( \pm 9.0 \mathrm{E}-02,3.9 \mathrm{E} 00)$ & $2.40 \mathrm{E} 00( \pm 6.3 \mathrm{E}-02,2.6 \mathrm{E} 00)$ \\
\hline $\mathrm{Na}$ & $1.74 \mathrm{E} 01( \pm 1.7 \mathrm{E}-01,9.7 \mathrm{E}-01)$ & $1.77 \mathrm{E} 01( \pm 4.0 \mathrm{E}-01,2.2 \mathrm{E}-01)$ \\
\hline $\mathrm{Ni}$ & $2.35 \mathrm{E} 00( \pm 2.6 \mathrm{E}-02,1.1 \mathrm{E} 00)$ & $2.40 \mathrm{E} 00( \pm 5.5 \mathrm{E}-02,2.3 \mathrm{E} 00)$ \\
\hline $\mathrm{Pb}$ & $1.20 \mathrm{E}-01( \pm 5.2 \mathrm{E}-03,4.3 \mathrm{E} 00)$ & $1.15 \mathrm{E}-01( \pm 4.4 \mathrm{E}-03,3.8 \mathrm{E} 00)$ \\
\hline $\mathrm{Si}$ & $1.04 \mathrm{E}-01( \pm 2.5 \mathrm{E}-03,2.4 \mathrm{E} 00)$ & $9.85 \mathrm{E}-02( \pm 3.6 \mathrm{E}-03,3.7 \mathrm{E} 00)$ \\
\hline $\mathrm{U}$ & $2.59 \mathrm{E}-01( \pm 1.2 \mathrm{E}-02,4.5 \mathrm{E} 00)$ & $2.44 \mathrm{E}-01( \pm 8.1 \mathrm{E}-03,3.3 \mathrm{E} 00)$ \\
\hline $\mathrm{Zn}$ & $2.15 \mathrm{E}-01( \pm 2.6 \mathrm{E}-03,1.2 \mathrm{E} 00)$ & $2.18 \mathrm{E}-01( \pm 4.8 \mathrm{E}-03,2.2 \mathrm{E} 00)$ \\
\hline
\end{tabular}

${ }^{a} \mathrm{Si}$ was added to the table because it exceeded the $0.1 \mathrm{wt} . \%$ criteria. However, this number should not be used because it is known that this dissolution method does not dissolve all of the $\mathrm{Si}$.

${ }^{b}$ Results are determined by ICP-ES and are the averages of results of three samples of dissolved dried slurry. The standard deviation and the percent relative standard deviation are presented in parentheses next to each value.

The results for the Sludge Batch 3 simulant in Table 5 and Table 6 show good agreement between the first wash top and bottom samples and second wash top and bottom samples. This good agreement suggests that the samples were well mixed when the top and bottom samples were taken, and that the $\mathrm{Pu} / \mathrm{Gd}$ mixture is evenly distributed throughout the Sludge Batch 3 simulant in the washing vessel. The values presented in Table 6 are higher than those presented in Table 5 except for $\mathrm{Na}$. This is due to the removal of $\mathrm{Na}$ and associated soluble anions during the washing process. 
The concentration of the Gd in Table 5 and Table 6 can be compared to the concentrations predicted from the amount of $\mathrm{Pu} / \mathrm{Gd}$ added to the Sludge Batch 3 simulant, and the dried total solids predicted from the Excel Washing spreadsheet for both washes. The predicted weight percent of Gd in the first wash for the Sludge Batch 3 simulant was 3.08E-02 wt.\% (7.96E-02g of Gd/258g of dried total solids*100). The predicted weight percent of Gd in the second wash for the Sludge Batch 3 simulant was 5.85E-02 wt.\% (7.72E-02g of Gd/ 132g of dried solids*100). The Gd values presented in Table 5 and Table 6 are approximately $20 \%$ to $23 \%$ higher than the calculated value of $3.08 \mathrm{E}-02 \mathrm{wt} . \%$ and $5.85 \mathrm{E}-02 \mathrm{wt} . \%$ respectively. This may be due to a systematic analytical error. A comparison of the ICP-ES data to the Inductively Coupled Plasma Mass Spectroscopy (ICP-MS) data for Gd will be completed in Section 2.3.3 to see if higher concentrations for Gd are also obtained.

\subsubsection{ICP-MS and Counting Results for the Top and Bottom Samples for the First and Second Washes for the Sludge Batch 3 Simulant}

Presented below in Table 7 and Table 8 are the results from the ICP-MS and radioactive counting methods for the top and bottom samples for the first and second wash of the Sludge Batch 3 simulant. The dissolution solutions described in Section 2.3.2 were used for the analyses. The units used for the ICP-MS results and the counting methods are presented next to each value. The standard deviation and the percent relative standard deviations for the values are presented in parentheses.

Table 7 - ICP-MS Results and Counting Results for the Top and Bottom Samples for the First Wash of Sludge Batch 3

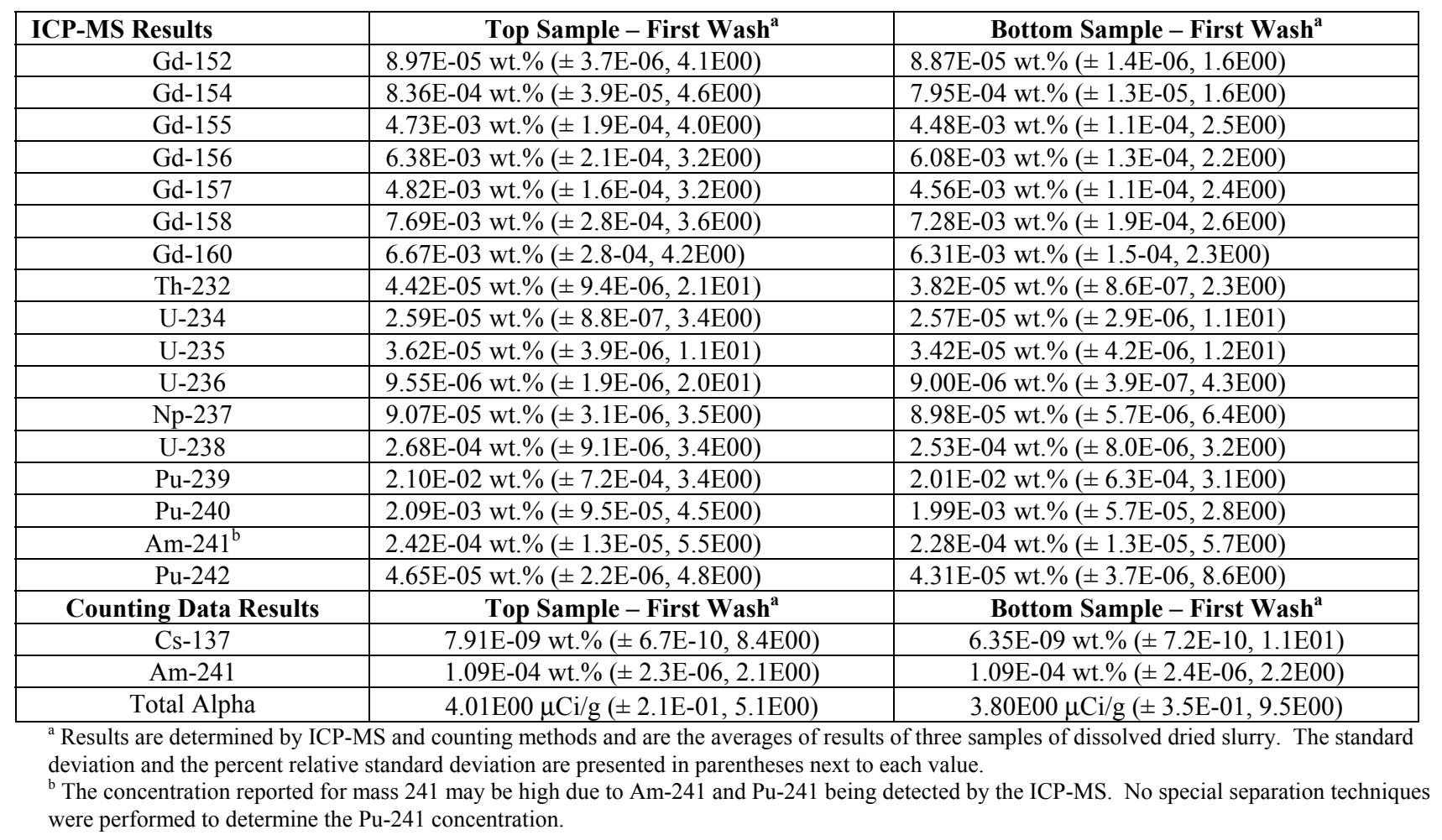


Table 8 - ICP-MS Results and Counting Results for the Top and Bottom Samples for the Second Wash of Sludge Batch 3

\begin{tabular}{|c|c|c|}
\hline ICP-MS Results & Top Sample - Second Wash ${ }^{\mathrm{a}}$ & Bottom Sample - Second Wash ${ }^{\mathrm{a}}$ \\
\hline Gd-152 & $1.48 \mathrm{E}-04$ wt.\% $( \pm 1.3 \mathrm{E}-06,9.0 \mathrm{E}-01)$ & 1.44E-04 wt.\% $( \pm 1.1 \mathrm{E}-05,7.6 \mathrm{E} 00)$ \\
\hline Gd-154 & 1.49E-03 wt.\% $( \pm 2.5 \mathrm{E}-05,1.7 \mathrm{E} 00)$ & $1.48 \mathrm{E}-03$ wt. $\%( \pm 7.8 \mathrm{E}-05,5.3 \mathrm{E} 00)$ \\
\hline Gd-155 & 9.14E-03 wt.\% ( $\%$ 7.3E-05, 8.0E-01) & $9.06 \mathrm{E}-03$ wt. $\%( \pm 4.0 \mathrm{E}-04,4.4 \mathrm{E} 00)$ \\
\hline Gd-156 & $1.26 \mathrm{E}-02$ wt. $\%( \pm 1.2 \mathrm{E}-04,9.5 \mathrm{E}-01)$ & $1.25 \mathrm{E}-02$ wt. $\%( \pm 5.3 \mathrm{E}-04,4.2 \mathrm{E} 00)$ \\
\hline Gd-157 & $9.56 \mathrm{E}-03$ wt. $\%( \pm 9.1 \mathrm{E}-05,9.5 \mathrm{E}-01)$ & $9.48 \mathrm{E}-03$ wt. $\%( \pm 4.0 \mathrm{E}-04,4.3 \mathrm{E} 00)$ \\
\hline Gd-158 & $1.53 \mathrm{E}-02$ wt. $\%( \pm 1.3 \mathrm{E}-04,8.5 \mathrm{E}-01)$ & $1.52 \mathrm{E}-02$ wt. $\%( \pm 6.6 \mathrm{E}-04,4.4 \mathrm{E} 00)$ \\
\hline Gd-160 & $1.33 \mathrm{E}-02$ wt. $\%( \pm 1.1-04,8.6 \mathrm{E}-01)$ & $1.32 \mathrm{E}-02$ wt. $\%( \pm 5.6-04,4.3 \mathrm{E} 00)$ \\
\hline Th-232 & 7.62E-05 wt.\% ( $( \pm$ 7.9E-06, 1.0E01) & 7.57E-05 wt.\% $( \pm 1.2 \mathrm{E}-06,1.5 \mathrm{E} 00)$ \\
\hline $\mathrm{U}-234$ & $4.88 \mathrm{E}-05$ wt. $\%( \pm 8.7 \mathrm{E}-07,1.8 \mathrm{E} 00)$ & 4.54E-05 wt. $\%( \pm 4.9 \mathrm{E}-06,1.1 \mathrm{E} 01)$ \\
\hline $\mathrm{U}-235$ & 7.04E-05 wt. $\%( \pm 2.2 \mathrm{E}-06,3.1 \mathrm{E} 00)$ & 7.48E-05 wt. $\%$ ( \pm 8.0E-06, 1.1E01) \\
\hline $\mathrm{U}-236$ & $2.00 \mathrm{E}-05$ wt. $\%( \pm 2.0 \mathrm{E}-06,9.9 \mathrm{E} 00)$ & $1.90 \mathrm{E}-05$ wt. $\%( \pm 2.5 \mathrm{E}-06,1.3 \mathrm{E} 01)$ \\
\hline $\mathrm{Np}-237$ & $1.94 \mathrm{E}-04$ wt. $\%( \pm 5.3 \mathrm{E}-06,2.8 \mathrm{E} 00)$ & $2.02 \mathrm{E}-04$ wt. $\%( \pm 1.8 \mathrm{E}-05,9.0 \mathrm{E} 00)$ \\
\hline U-238 & 4.80E-04 wt.\% $( \pm 1.3 \mathrm{E}-05,2.7 \mathrm{E} 00)$ & 4.81E-04 wt.\% $( \pm 2.5 \mathrm{E}-05,5.3 \mathrm{E} 00)$ \\
\hline $\mathrm{Pu}-239$ & 4.15E-02 wt.\% ( $( \pm 1.5 \mathrm{E}-04,3.7 \mathrm{E}-01)$ & 4.14E-02 wt.\% $( \pm 2.3 \mathrm{E}-03,5.6 \mathrm{E} 00)$ \\
\hline $\mathrm{Pu}-240$ & 4.07E-03 wt.\% $( \pm 2.6 \mathrm{E}-05,6.3 \mathrm{E}-01)$ & 4.07E-03 wt. $\%( \pm 2.0 \mathrm{E}-04,5.0 \mathrm{E} 00)$ \\
\hline $\mathrm{Am}-241^{\mathrm{b}}$ & $4.55 \mathrm{E}-04$ wt. $\%$ ( $( \pm 7.3 \mathrm{E}-06,1.6 \mathrm{E} 00)$ & 4.54E-04 wt.\% $( \pm 2.5 \mathrm{E}-05,5.4 \mathrm{E} 00)$ \\
\hline $\mathrm{Pu}-242$ & $8.82 \mathrm{E}-05$ wt.\% $( \pm 6.6 \mathrm{E}-06,7.5 \mathrm{E} 00)$ & $8.89 \mathrm{E}-05$ wt. $\%( \pm 5.5 \mathrm{E}-06,6.1 \mathrm{E} 00)$ \\
\hline Counting Data Results & Top Sample - Second Wash & Bottom Sample - Second Wash \\
\hline Cs- $137^{\mathrm{c}}$ & $<5.8 \mathrm{E}-09$ wt. $\%$ & $<3.3 \mathrm{E}-09$ wt. $\%$ \\
\hline $\mathrm{Am}-241^{\mathrm{a}}$ & $2.37 \mathrm{E}-04$ wt. $\%( \pm 4.4 \mathrm{E}-05,1.9 \mathrm{E} 01)$ & $2.10 \mathrm{E}-04$ wt.\% $( \pm 3.7 \mathrm{E}-06,1.8 \mathrm{E} 00)$ \\
\hline Total Alpha $^{\mathrm{a}}$ & $7.46 \mathrm{E} 00 \mu \mathrm{Ci} / \mathrm{g}( \pm 1.3 \mathrm{E}-01,1.7 \mathrm{E} 00)$ & 7.34E00 $\mu \mathrm{Ci} / \mathrm{g}( \pm 5.2 \mathrm{E}-01,7.1 \mathrm{E} 00)$ \\
\hline
\end{tabular}

${ }^{a}$ Results are determined by ICP-MS and counting methods and are the averages of results of three samples of dissolved dried slurry. The standard deviation and the percent relative standard deviation are presented in parentheses next to each value.

${ }^{\mathrm{b}}$ The concentration reported for mass 241 may be high due to Am-241 and Pu-241 being detected by the ICP-MS. No special separation techniques were performed to determine the Pu-241 concentration.

${ }^{\mathrm{c}}$ Detection limit of the method.

The responses for masses 152, 154 through 158, and 160 were attributed to Gd because they followed the natural abundance for Gd. Adding these masses together in Table 7 yielded an average Gd value, for the top and bottom samples, of 3.04E-02 wt.\% versus 3.86E-02 wt.\% obtained by ICP-ES. This value was then compared to the predicted weight percent value for Gd for the first wash. The difference between the predicted weight percent and ICP-MS values were $1.3 \%$ versus the $20 \%$ obtained with the ICP-ES data. The same method was used to compare the Gd values in Table 8. The average Gd values in Table 8 were $6.13 \mathrm{E}-02 \mathrm{Wt} . \%$. This value was then compared to the predicted weight percent value for Gd for the second wash. The difference between the predicted weight percent and ICP-MS values were $4.8 \%$ versus the $23 \%$ obtained with the ICP-ES data. Based on this data, it appears the ICP-MS values are more accurate than the ICP-ES results for Gd. An investigation of the ICP-ES Gd data is being conducted to resolve the differences observed between the ICP-ES and ICP-MS data.

The same comparison of the $\mathrm{Pu}$ in the Sludge Batch 3 simulant was completed for the first and second wash. The predicted amount of Pu for the first wash was $2.20 \mathrm{E}-2 \mathrm{wt} . \%$ (5.68E-02g of Pu/258g of dried total solids*100). The predicted amount of Pu for the second wash was 4.18E-02 wt.\% (5.51E-02g of Pu/ $132 \mathrm{~g}$ of dried solids*100). Adding the Pu isotopes $(239,240,242)$ together for Table 7 yields a value of 2.26E-02 wt.\% and 4.56E-02 wt.\% respectively. The differences between the predicted Pu weight percent and the actual weight percents for the first and second wash are $2.7 \%$ and $9.1 \%$.

The ratio of the $\mathrm{Gd}$ to the $\mathrm{Pu}$ for the $\mathrm{Pu} / \mathrm{Gd}$ mixture is 1.40 to $1^{4}$. Using the analytical data for the $\mathrm{Gd}$ and $\mathrm{Pu}$ in Table 7 the ratio of $\mathrm{Gd}$ to $\mathrm{Pu}$ is $1.34: 1$. The differences in the ratios from the predicted ratio are reasonable, and are probably due to analytical error surrounding the measurement of the low concentrations of $\mathrm{Gd}$ and $\mathrm{Pu}$ in the sludge slurry. 


\subsubsection{Comparison of the Nonradioactive Composition for the Supernate of the Top and Bottom Samples for the First Wash and the Top and Bottom Samples for the Second Wash}

Provided below are the results from the analyses of the supernate of the top and bottom samples for both washes of the Sludge Batch 3 simulant. Mixed samples of the sludge slurry were filtered through a Nalgene ${ }^{\circledR}$ filter $(0.45 \mu \mathrm{m})$ resulting in clear supernate solutions. The supernate solutions were then diluted to make sure the $\mathrm{Na}$ concentration was within the limits of analytical method. Elemental standards were also submitted with the supernate samples to check the analytical methods. These diluted samples were sent to ADS Sample Receiving so that analyses could be performed by ADS. The results for the elemental standards submitted with the supernate indicated good agreement with the known values of the standards. Table 9 presents the elements with concentrations $>1 \mathrm{ppm}(\mathrm{mg} / \mathrm{L}$ of supernate) in the supernate for the top and bottom samples for the first wash of the Sludge Batch 3 simulant obtained from the ICP- ES and the Ion Chromatography (IC). Table 9 also presents the standard deviation and the percent relative standard deviation in parentheses next to the ppm value. Table 10 presents the elements with concentrations $>1 \mathrm{ppm}$ $(\mathrm{mg} / \mathrm{L}$ of supernate) in the supernate for the top and bottom samples for the second wash of the Sludge Batch 3 simulant obtained from the ICP- ES (ICP-ES) and the Ion Chromatography (IC). Table 10 also presents the standard deviation and the percent relative standard deviation in parentheses next to the ppm value.

Table 9 - ICP-ES and IC Supernate Results for Top and Bottom Samples for the First Wash of the Sludge Batch 3 Simulant

\begin{tabular}{|c|c|c|}
\hline ICP-ES Results & Top Sample - First Wash ${ }^{\mathrm{c}}$ & Bottom Sample - First Wash ${ }^{c}$ \\
\hline $\mathrm{Al}$ & 4.70E03 mg/L Supernate $( \pm 5.7 \mathrm{E} 01,1.2 \mathrm{E} 00)$ & $4.63 \mathrm{E} 03 \mathrm{mg} / \mathrm{L}$ Supernate $( \pm 3.6 \mathrm{E} 01,7.8 \mathrm{E}-01)$ \\
\hline $\mathrm{B}$ & 5.99E01 mg/L Supernate $( \pm 5.1 \mathrm{E}-01,8.5 \mathrm{E}-01)$ & $5.51 \mathrm{E} 01 \mathrm{mg} / \mathrm{L}$ Supernate $( \pm 3.6 \mathrm{E}-01,6.6 \mathrm{E}-01)$ \\
\hline $\mathrm{Ca}$ & 7.39E00 mg/L Supernate $( \pm 3.3 \mathrm{E}-01,4.5 \mathrm{E} 00)$ & $8.63 \mathrm{E} 00 \mathrm{mg} / \mathrm{L}$ Supernate $( \pm 2.6 \mathrm{E}-01,3.1 \mathrm{E} 00)$ \\
\hline $\mathrm{Cr}$ & 3.34E00 mg/L Supernate $( \pm 7.0 \mathrm{E}-02,2.2 \mathrm{E} 00)$ & $3.13 \mathrm{E} 00 \mathrm{mg} / \mathrm{L}$ Supernate $( \pm 3.0 \mathrm{E}-02,8.5 \mathrm{E}-01)$ \\
\hline $\mathrm{Gd}^{\mathrm{a}}$ & $3.7 \mathrm{E}-01 \mathrm{mg} / \mathrm{L}$ Supernate $( \pm 6.0 \mathrm{E}-02,1.7 \mathrm{E} 01)$ & $<2.3 \mathrm{E}-01 \mathrm{mg} / \mathrm{L}$ Supernate ${ }^{\mathrm{b}}$ \\
\hline Mo & 2.64E00 mg/L Supernate $( \pm 2.0 \mathrm{E}-02,6.9 \mathrm{E}-01)$ & $2.31 \mathrm{E} 00 \mathrm{mg} / \mathrm{L}$ Supernate $( \pm 2.0 \mathrm{E}-02,8.7 \mathrm{E}-01)$ \\
\hline $\mathrm{Na}$ & 3.91E04 mg/L Supernate $( \pm 2.3 \mathrm{E} 03,5.8 \mathrm{E} 00)$ & 3.89E04 mg/L Supernate $( \pm 4.6 \mathrm{E} 03,1.2 \mathrm{E} 00)$ \\
\hline $\mathrm{P}$ & $1.28 \mathrm{E} 01 \mathrm{mg} / \mathrm{L}$ Supernate $( \pm 2.2 \mathrm{E} 00,1.7 \mathrm{E} 01)$ & $1.26 \mathrm{E} 01 \mathrm{mg} / \mathrm{L}$ Supernate $( \pm 1.0 \mathrm{E} 00,7.9 \mathrm{E} 00)$ \\
\hline $\mathrm{Pb}$ & $3.58 \mathrm{E} 00 \mathrm{mg} / \mathrm{L}$ Supernate $( \pm 1.8 \mathrm{E}-01,5.0 \mathrm{E} 00)$ & $2.45 \mathrm{E} 00 \mathrm{mg} / \mathrm{L}$ Supernate $( \pm 1.4 \mathrm{E}-01,5.8 \mathrm{E} 00)$ \\
\hline $\mathrm{Sn}$ & $5.04 \mathrm{E} 00 \mathrm{mg} / \mathrm{L}$ Supernate $( \pm 7.7 \mathrm{E}-01,1.5 \mathrm{E} 01)$ & 4.09E00 mg/L Supernate $( \pm 3.2 \mathrm{E}-01,7.9 \mathrm{E} 00)$ \\
\hline $\mathrm{U}$ & $7.30 \mathrm{E} 00 \mathrm{mg} / \mathrm{L}$ Supernate $( \pm 2.4 \mathrm{E}-01,3.3 \mathrm{E} 00)$ & $3.81 \mathrm{E} 00 \mathrm{mg} / \mathrm{L}$ Supernate $( \pm 3.0 \mathrm{E}-01,7.8 \mathrm{E} 00)$ \\
\hline $\mathrm{Zn}$ & $1.63 \mathrm{E} 00 \mathrm{mg} / \mathrm{L}$ Supernate $( \pm 3.0 \mathrm{E}-02,1.7 \mathrm{E} 00)$ & $1.35 \mathrm{E} 00 \mathrm{mg} / \mathrm{L}$ Supernate $( \pm 3.0 \mathrm{E}-02,2.0 \mathrm{E} 00)$ \\
\hline IC Results & Top Sample - First Wash ${ }^{\mathrm{c}}$ & Bottom Sample - First Wash ${ }^{\mathrm{c}}$ \\
\hline Flouride $^{\mathrm{b}}$ & $<32 \mathrm{mg} / \mathrm{L}$ Supernate & $<35 \mathrm{mg} / \mathrm{L}$ Supernate \\
\hline Formate $^{b}$ & $<158 \mathrm{mg} / \mathrm{L}$ Supernate & $<174 \mathrm{mg} / \mathrm{L}$ Supernate \\
\hline Chloride & $2.59 \mathrm{E} 03( \pm 9.1 \mathrm{E} 00,3.5 \mathrm{E}-01)$ & $2.50 \mathrm{E} 03( \pm 2.2 \mathrm{E} 02,8.8 \mathrm{E} 00)$ \\
\hline Nitrite & $2.86 \mathrm{E} 04( \pm 1.8 \mathrm{E} 02,6.4 \mathrm{E}-01)$ & $2.96 \mathrm{E} 04( \pm 2.3 \mathrm{E} 03,7.8 \mathrm{E} 00)$ \\
\hline Nitrate & $1.06 \mathrm{E} 04( \pm 1.0 \mathrm{E} 03,9.7 \mathrm{E} 00)$ & $1.06 \mathrm{E} 04( \pm 1.3 \mathrm{E} 03,1.2 \mathrm{E} 01)$ \\
\hline Phosphate $^{b}$ & $<158 \mathrm{mg} / \mathrm{L}$ Supernate & $<174 \mathrm{mg} / \mathrm{L}$ Supernate \\
\hline Sulfate & $1.96 \mathrm{E} 03 \mathrm{mg} / \mathrm{L}$ Supernate $( \pm 9.1 \mathrm{E} 00,4.7 \mathrm{E}-01)$ & $1.89 \mathrm{E} 03 \mathrm{mg} / \mathrm{L}$ Supernate $( \pm 1.8 \mathrm{E} 02,9.3 \mathrm{E} 00)$ \\
\hline Oxalate $^{b}$ & $<158 \mathrm{mg} / \mathrm{L}$ Supernate & $<174 \mathrm{mg} / \mathrm{L}$ Supernate \\
\hline
\end{tabular}

${ }^{a} \mathrm{Gd}$ was added to the table since this is a Study of $\mathrm{Pu} / \mathrm{Gd}$ solubility during the washing process.

${ }^{\mathrm{b}}$ Detection limit of the analytical method.

${ }^{\mathrm{c}}$ Results are determined by ICP-ES and IC and are the averages of results of three samples unless otherwise indicated. The standard deviation and the percent relative standard deviation are presented in parentheses next to each value. 
Westinghouse Savannah River Company

WSRC-TR-2002-00208

Savannah River Technology Center

Page 15 of 41

Table 10 - ICP-ES and IC Supernate Results for Top and Bottom Samples for the Second Wash of the Sludge Batch 3 Simulant

\begin{tabular}{|c|c|c|}
\hline ICP-ES Results & Top Sample - Second Wash ${ }^{\mathrm{b}}$ & Bottom Sample - Second Wash ${ }^{\text {b }}$ \\
\hline $\mathrm{Al}$ & $1.43 \mathrm{E} 03 \mathrm{mg} / \mathrm{L}$ Supernate $( \pm 1.8 \mathrm{E} 00,1.3 \mathrm{E}-01)$ & $1.41 \mathrm{E} 03 \mathrm{mg} / \mathrm{L}$ Supernate $( \pm 5.5 \mathrm{E} 01,3.9 \mathrm{E} 00)$ \\
\hline $\mathrm{B}$ & $1.77 \mathrm{E} 01 \mathrm{mg} / \mathrm{L}$ Supernate $( \pm 1.4 \mathrm{E}-01,7.8 \mathrm{E}-01)$ & $1.83 \mathrm{E} 01 \mathrm{mg} / \mathrm{L}$ Supernate $( \pm 2.0 \mathrm{E}-01,1.1 \mathrm{E}-01)$ \\
\hline $\mathrm{Ca}$ & 9.41E00 mg/L Supernate $( \pm$ 5.7E-01, 6.1E00) & 7.39E00 mg/L Supernate $( \pm 1.2 \mathrm{E} 00,1.7 \mathrm{E} 01)$ \\
\hline $\mathrm{Cr}$ & $1.30 \mathrm{E} 00 \mathrm{mg} / \mathrm{L}$ Supernate $( \pm 1.7 \mathrm{E}-01,1.3 \mathrm{E} 01)$ & $1.62 \mathrm{E} 00 \mathrm{mg} / \mathrm{L}$ Supernate $( \pm 8.0 \mathrm{E}-02,4.8 \mathrm{E} 00)$ \\
\hline Gd & $3.1 \mathrm{E}-01 \mathrm{mg} / \mathrm{L} \mathrm{Supernate}{ }^{\mathrm{c}}$ & $4.5 \mathrm{E}-01 \mathrm{mg} / \mathrm{L}$ Supernate $( \pm 9.0 \mathrm{E}-01,1.9 \mathrm{E} 01)$ \\
\hline Mo & 9.40E-01 mg/L Supernate $( \pm 6.0 \mathrm{E}-02,5.9 \mathrm{E}-01)$ & $1.06 \mathrm{E} 00 \mathrm{mg} / \mathrm{L}$ Supernate $( \pm 4.0 \mathrm{E}-02,3.3 \mathrm{E} 00)$ \\
\hline $\mathrm{Na}$ & 1.34E04 mg/L Supernate $( \pm 1.3 \mathrm{E} 02,9.6 \mathrm{E}-01)$ & $1.26 \mathrm{E} 04 \mathrm{mg} / \mathrm{L}$ Supernate $( \pm 4.3 \mathrm{E} 02,3.4 \mathrm{E} 00)$ \\
\hline $\mathrm{P}$ & 7.35E00 mg/L Supernate $( \pm 6.6 \mathrm{E}-01,9.0 \mathrm{E} 00)$ & $7.56 \mathrm{E} 00 \mathrm{mg} / \mathrm{L}$ Supernate $( \pm 9.5 \mathrm{E}-01,1.3 \mathrm{E} 01)$ \\
\hline $\mathrm{Pb}$ & $1.38 \mathrm{E} 00 \mathrm{mg} / \mathrm{L}$ Supernate $( \pm$ 5.5E-01, 4.0E01) & $1.79 \mathrm{E} 00 \mathrm{mg} / \mathrm{L}$ Supernate $( \pm 2.2 \mathrm{E}-01,1.3 \mathrm{E} 01)$ \\
\hline $\mathrm{Sn}$ & $3.19 \mathrm{E} 00 \mathrm{mg} / \mathrm{L}$ Supernate $( \pm 2.3 \mathrm{E}-01,7.2 \mathrm{E} 00)$ & $3.07 \mathrm{E} 00 \mathrm{mg} / \mathrm{L}$ Supernate $( \pm 7.0 \mathrm{E}-02,2.3 \mathrm{E} 00)$ \\
\hline $\mathrm{U}$ & $3.35 \mathrm{E} 00 \mathrm{mg} / \mathrm{L}$ Supernate $( \pm 1.8 \mathrm{E} 00,5.2 \mathrm{E} 01)$ & 7.45E00 mg/L Supernate $( \pm 1.2 \mathrm{E} 00,1.6 \mathrm{E} 01)$ \\
\hline IC Results & Top Sample - First Wash ${ }^{\text {b }}$ & Bottom Sample - First Wash ${ }^{\text {b }}$ \\
\hline Flouride $^{\mathrm{a}}$ & $<37 \mathrm{mg} / \mathrm{L}$ Supernate & $<34 \mathrm{mg} / \mathrm{L}$ Supernate \\
\hline Formate $^{\mathrm{a}}$ & $<184 \mathrm{mg} / \mathrm{L}$ Supernate & $<169 \mathrm{mg} / \mathrm{L}$ Supernate \\
\hline Chloride & 7.13E02 ( $\pm 1.1 \mathrm{E} 01,1.5 \mathrm{E} 00)$ & 5.99E02 (土9.8E00, 1.6Е00) \\
\hline Nitrite & $9.22 \mathrm{E} 03( \pm 1.1 \mathrm{E} 02,1.2 \mathrm{E} 00)$ & 7.82E03 ( $\pm 2.5 \mathrm{E} 01,3.3 \mathrm{E}-01)$ \\
\hline Nitrate & $3.34 \mathrm{E} 03( \pm 1.8 \mathrm{E} 02,5.5 \mathrm{E}-01)$ & $2.82 \mathrm{E} 03( \pm 9.8 \mathrm{E} 00,3.5 \mathrm{E}-01)$ \\
\hline Phosphate $^{\mathrm{a}}$ & $<184 \mathrm{mg} / \mathrm{L}$ Supernate & $<169 \mathrm{mg} / \mathrm{L}$ Supernate \\
\hline Sulfate & $5.71 \mathrm{E} 02 \mathrm{mg} / \mathrm{L}$ Supernate $( \pm 7.6 \mathrm{E}-06,1.3 \mathrm{E}-06)$ & 4.92E02 mg/L Supernate $( \pm 0,0)^{\mathrm{d}}$ \\
\hline Oxalate $^{\mathrm{a}}$ & $<184 \mathrm{mg} / \mathrm{L}$ Supernate & $<169 \mathrm{mg} / \mathrm{L}$ Supernate \\
\hline
\end{tabular}

\subsubsection{ICP-MS and Counting Results of the Supernate for the Top and Bottom Samples for the First and Second Washes for the Sludge Batch 3 Simulant}

Presented below in Table 11 and Table 12 are the results of the supernate from the ICP-MS and radioactive counting methods for the top and bottom samples for the first and second wash of the Sludge Batch 3 simulant. The supernate solutions described in Section 2.3.4 were used for the analyses. The units used for the ICP-MS results and the counting methods are presented next to each value. The standard deviation and the percent relative standard deviations for the values are presented in parentheses.

Table 11 - ICP-MS and Counting Results of the Supernate for the First Wash Top and Bottom Samples of the Sludge Batch 3 Simulant

\begin{tabular}{|c|c|c|}
\hline ICP-MS Results & $\begin{array}{c}\text { Top Sample - First Wash } \\
\end{array}$ & Bottom Sample - First Wash ${ }^{\mathrm{a}}$ \\
\hline U-234 & $4.55 \mathrm{E}-03 \mathrm{mg} / \mathrm{L}$ Supernate $( \pm$ 5.7E-04, 1.2E01) & $6.91 \mathrm{E}-03 \mathrm{mg} / \mathrm{L}$ Supernate $( \pm$ 5.1E-04, 7.3E00) \\
\hline U-235 & 7.48E-03 mg/L Supernate $( \pm$ 5.7E-04, 7.6E00) & $1.0 \mathrm{E}-02 \mathrm{mg} / \mathrm{L}$ Supernate $( \pm 4.1 \mathrm{E}-04,4.1 \mathrm{E} 00)$ \\
\hline $\mathrm{Np}-237$ & 7.24E-03 mg/L Supernate ( \pm 5.5E-04, 7.6E00) & 7.77E-03 mg/L Supernate $( \pm$ 4.9E-04, 6.3E00) \\
\hline $\mathrm{U}-238$ & $2.78 \mathrm{E}-02 \mathrm{mg} / \mathrm{L}$ Supernate $( \pm 1.2 \mathrm{E}-03,4.4 \mathrm{E} 00)$ & $3.80 \mathrm{E}-02 \mathrm{mg} / \mathrm{L}$ Supernate $( \pm 2.7 \mathrm{E}-03,7.2 \mathrm{E} 00)$ \\
\hline $\mathrm{Pu}-239$ & $5.32 \mathrm{E}-02 \mathrm{mg} / \mathrm{L}$ Supernate $( \pm 3.0 \mathrm{E}-03,5.6 \mathrm{E} 00)$ & $6.57 \mathrm{E}-02 \mathrm{mg} / \mathrm{L}$ Supernate $( \pm 5.7 \mathrm{E}-03,8.6 \mathrm{E} 00)$ \\
\hline $\mathrm{Pu}-240$ & 4.97E-03 mg/L Supernate $( \pm 9.7 \mathrm{E}-05,1.9 \mathrm{E} 00)$ & $6.57 \mathrm{E}-03 \mathrm{mg} / \mathrm{L}$ Supernate $( \pm 7.88 \mathrm{E}-04,1.2 \mathrm{E} 01)$ \\
\hline $\begin{array}{c}\text { Counting Data } \\
\text { Results } \\
\end{array}$ & Top Sample - First Wash ${ }^{\mathrm{a}}$ & Bottom Sample - First Wash ${ }^{\text {a }}$ \\
\hline Cs-137 & 9.20E-04 $\mu \mathrm{Ci} / \mathrm{mL}$ Supernate $( \pm 5.6 \mathrm{E}-05,6.1 \mathrm{E} 00)$ & $8.88 \mathrm{E}-04 \mu \mathrm{Ci} / \mathrm{mL}$ Supernate $( \pm 6.1 \mathrm{E}-05,6.9 \mathrm{E} 00)$ \\
\hline Total Alpha & $1.53 \mathrm{E} 04 \mathrm{dpm} / \mathrm{mL}$ Supernate $( \pm 8.6 \mathrm{E} 02,5.6 \mathrm{E} 00)$ & 1.65E04 dpm/mL Supernate $( \pm 1.3 \mathrm{E} 03,7.7 \mathrm{E} 00)$ \\
\hline
\end{tabular}


Table 12 - ICP-MS and Counting Results of the Supernate for the Second Wash Top and Bottom Samples of the Sludge Batch 3 Simulant

\begin{tabular}{|c|c|c|}
\hline ICP-MS Results & Top Sample - Second Wash ${ }^{\mathrm{a}}$ & Bottom Sample - Second Wash ${ }^{a}$ \\
\hline U-238 & $4.33 \mathrm{E}-03 \mathrm{mg} / \mathrm{L}$ Supernate $( \pm 1.5 \mathrm{E}-03,3.4 \mathrm{E} 01)$ & $3.60 \mathrm{E}-03 \mathrm{mg} / \mathrm{L}$ Supernate $( \pm 3.7 \mathrm{E}-04,1.0 \mathrm{E} 01)$ \\
\hline $\mathrm{Pu}-239$ & $3.55 \mathrm{E}-03 \mathrm{mg} / \mathrm{L}$ Supernate $( \pm 2.7 \mathrm{E}-04,7.5 \mathrm{E} 00)$ & $6.61 \mathrm{E}-03 \mathrm{mg} / \mathrm{L}$ Supernate $( \pm 3.3 \mathrm{E}-04,5.0 \mathrm{E} 00)$ \\
\hline $\begin{array}{c}\text { Counting Data } \\
\text { Results }\end{array}$ & Top Sample - Second Wash ${ }^{\mathrm{a}}$ & Bottom Sample - Second Wash ${ }^{\mathrm{a}}$ \\
\hline Cs-137 & $3.26 \mathrm{E}-04 \mu \mathrm{Ci} / \mathrm{mL}$ Supernate $( \pm 3.3 \mathrm{E}-05,1.0 \mathrm{E} 01)$ & $2.73 \mathrm{E}-04 \mu \mathrm{Ci} / \mathrm{mL}$ Supernate $( \pm 4.8 \mathrm{E}-05,1.8 \mathrm{E} 01)$ \\
\hline Total Alpha & $2.54 \mathrm{E} 03 \mathrm{dpm} / \mathrm{mL}$ Supernate $( \pm 1.3 \mathrm{E} 02,5.2 \mathrm{E} 00)$ & $2.57 \mathrm{E} 03 \mathrm{dpm} / \mathrm{mL}$ Supernate $( \pm 7.1 \mathrm{E} 01,2.8 \mathrm{E} 00)$ \\
\hline
\end{tabular}

${ }^{\mathrm{a}}$ Results are determined by ICP-MS and counting methods and are the averages of results of three samples. The standard deviation and the percent relative standard deviation are presented in parentheses next to each value.

No Gd was detected by the ICP-MS at masses 152, 154 through 158, and 160 in Table 11 and Table 12. The ICP-ES data indicates that Gd is present in the supernate except for the bottom sample from the first wash. As indicated earlier in Section 2.3.3, the ICP-ES data may be biased high.

\subsection{Summary of the First Wash and Second Wash Results for the Sludge Batch 3 Simulant}

Two washes of the Sludge Batch 3 simulant were completed with no processing problems. The first wash lowered the Na molarity of the supernate from 4.64M (see Table 3 for ppm value) to $1.79 \mathrm{M}$ (Table 9 for $\mathrm{ppm}$ value). The second wash lowered the Na molarity of the supernate from $1.79 \mathrm{M}$ to $0.57 \mathrm{M}$ (Table 10 for ppm value). This was outside of the Na molarity range of $0.45 \mathrm{M}$ to $0.55 \mathrm{M}$ specified in the Task Plan ${ }^{2}$. After discussion with Waste Disposition Engineering and Process Engineering, permission was obtained to proceed forward with the SRAT cycle using the Sludge Batch 3 simulant with a Na concentration of $0.57 \mathrm{M}^{7}$.

A summary of the Gd and Pu solubility during the first and second wash are presented below in Table 13 . Table 13 presents the grams of $\mathrm{Pu}$ and $\mathrm{Gd}$ that became soluble during the washing process. These values are presented on a sludge slurry basis.

Table 13 - Amount of Pu and Gd that Became Soluble During the Washing Process

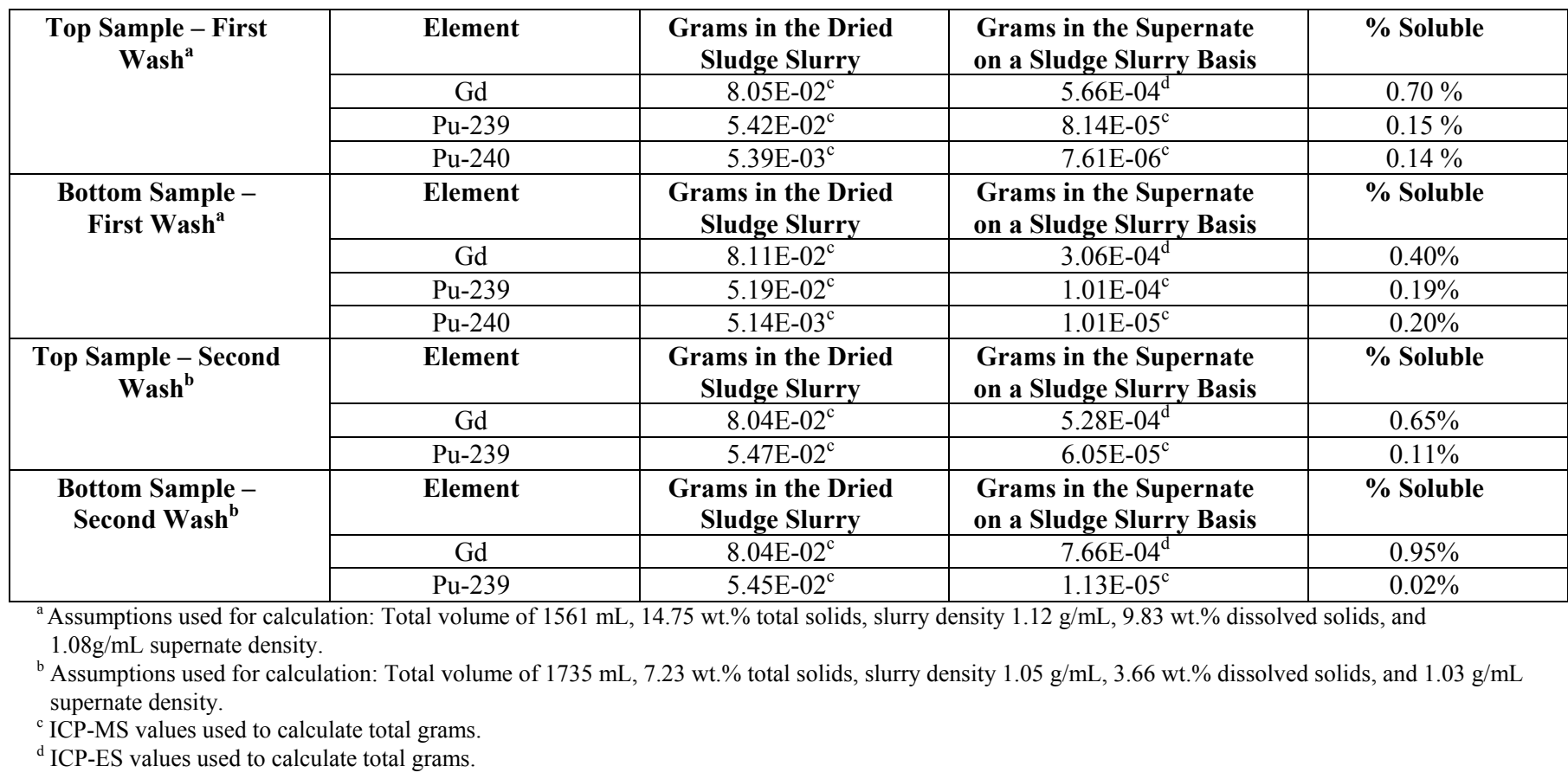

Since the ICP-MS did not detect Gd in the supernate, the grams of Gd noted in the fourth column of Table 13 are calculated from the concentrations obtained from the ICP-ES. The ICP-ES results could be biased high based on results observed earlier for the sludge slurry. The Gd results from the ICP-ES (in the fourth 
column) provided a conservative estimate for the amount of Gd that was soluble during this washing test. For the first wash, the fraction of Gd ranged from $0 \%$ (using the ICP-MS data) to $0.70 \%$ (using ICP-ES data) and the fraction of Pu ranged from $0.14 \%-0.20 \%$ (using ICP-MS data). For the second wash, the fraction of Gd ranged from $0 \%$ (using ICP-MS data) $-0.95 \%$ and the fraction of Pu ranged from $0.02 \%$ $0.11 \%$ (using ICP-MS data).

The amount of $\mathrm{Pu}$ that is soluble during the washing process is important, because it contributes alpha activity to the supernate. The decanted supernate solutions from the washing process are evaporated in the High Level Waste evaporator system and the overheads are sent to the Effluent Treatment Facility (ETF). The bottoms from the evaporator will be sent to Saltstone for processing. To estimate the alpha activity of the wash solutions from this experiment, the counting results for the total alpha activity (highest value between the two results were used) in Table 11 and Table 12 were used. Referencing engineering position paper - HLW-SDT-2001-00244 ${ }^{8}$, a decontamination factor of $1.0 \mathrm{E} 04^{9}$ was assumed for the solution entrained in the evaporator vapor stream. The estimated activities for the first wash and second wash in the evaporator overheads are $1.7 \mathrm{dpm} / \mathrm{mL}$ and $2.6 \mathrm{E}-01 \mathrm{dpm} / \mathrm{mL}$ respectively. The alpha activities in the evaporator overheads should not be an issue for ETF, because they meet the ETF acceptance criteria of 100 $\mathrm{dpm} / \mathrm{mL}^{10}$. Prior to processing the bottoms from the evaporator through Saltstone, the solutions will be treated with a sorbant to remove the alpha emitters to meet the $20 \mathrm{nCi} / \mathrm{g}$ acceptance criteria for Saltstone ${ }^{11}$.

The $\mathrm{Pu}$ concentrations obtained from the experimental washing study were also compared to the results obtained from an Excel spreadsheet model that predicted Pu solubility. A direct comparison between the predicted and measured concentrations was not possible since the hydroxide concentration was not measured during the washing tests. However, the measured plutonium concentrations in Table 11 and Table 12 fall within the predicted range of plutonium solubilities (3.77E-03 to $1.67 \mathrm{E}-01 \mathrm{mg} / \mathrm{L}$ reported by D. Hobbs for Sludge Batch $3^{12}$ ). Based on the quantity of added co-precipitated $\mathrm{Pu} / \mathrm{Gd}$ solids in the laboratory tests, between 0.02 and $0.20 \mathrm{wt} \%$ of the available plutonium leached from the solids. This percentage of leached plutonium is also within the range of 0.0018 to $0.42 \mathrm{wt} \%$ predicted during washing $^{11}$. These results indicate that the co-precipitated $\mathrm{Pu} / \mathrm{Gd}$ solids do not exhibit any unusual chemical behavior during sludge washing. The small quantities of leached plutonium during the sludge washing tests do not present a criticality safety concern and are not sufficient to adversely impact Salt Processing operations.

\subsection{ANALYTICAL RESULTS OF THE FINAL WASHED SLUDGE BATCH 3 SIMULANT}

The sections below provide a brief description of the analyses and results obtained from the final washed Sludge Batch 3 simulant and supernate. To obtain the supernate for the required analyses, a portion of the mixed sludge slurry was filtered.

\subsection{Weight Percent Solids and Density Measurements for the Final Washed Sludge Batch 3 Simulant and Supernate}

Weight percent solids measurements were completed for the sludge slurry and supernate as described in Section 2.3.1. The averages of the calculated results of the weight percent solids for the sludge slurry and the supernate (only one value obtained due to amount of sample available) are presented in column two and column three of Table 14 respectively. The standard deviations (Std. Dev.) and the percent relative standard deviations (\% RSD) for the data are also presented in column two and column three of Table 14.

Density measurements were completed by using heat sealed pipette tips. The pipette tips are first sealed and then calibrated with water to obtain the volume. Four density measurements were completed for the sludge slurry and supernate. The sealed pipette tip was first weighed and then a sample of the sludge slurry or supernate was pipetted into the sealed pipette tip. The sealed pipette tip containing the sludge slurry or supernate sample was weighed and a density calculated. The results of the sludge slurry and supernate for the final washed Sludge Batch 3 simulant are presented in column four and column five of Table 14. The standard deviations (Std. Dev.) 
and the percent relative standard deviations ( $\%$ RSD) for the data are also presented in column four and column five of Table 14.

Table 14 - Weight Percent Solids and Density Measurements for the Final Washed Sludge Batch 3 Simulant and Supernate

\begin{tabular}{|c|c|c|c|c|}
\hline & $\begin{array}{c}\text { Wt. \% Total Solids for } \\
\text { the Sludge Batch 3 } \\
\text { Simulant }^{\mathbf{a}}\end{array}$ & $\begin{array}{c}\text { Wt. \% Dissolved } \\
\text { Solids for the } \\
\text { Supernate }^{\mathbf{b}}\end{array}$ & $\begin{array}{c}\text { Density } \\
\text { Measurements for } \\
\text { the Sludge Batch 3 } \\
\text { Simulant }^{\mathbf{c}}\end{array}$ & $\begin{array}{c}\text { Density } \\
\text { Measurements for } \\
\text { the Supernate }^{\mathbf{c}}\end{array}$ \\
\hline Average & $15.30 \mathrm{wt} . \%$ & $3.32 \mathrm{wt} . \%$ & $1.14 \mathrm{~g} / \mathrm{mL}$ & $1.02 \mathrm{~g} / \mathrm{mL}$ \\
\hline Std. Dev. & $\pm 1.33 \mathrm{E}-01$ & - & $\pm 1.7 \mathrm{E}-03$ & $\pm 8.0 \mathrm{E}-03$ \\
\hline \%RSD & $8.70 \mathrm{E}-01$ & - & $1.5 \mathrm{E}-01$ & $7.9 \mathrm{E}-01$ \\
\hline
\end{tabular}

${ }^{\mathrm{a}}$ Sample(s) were dried at $110^{\circ} \mathrm{C}$ overnight.

${ }^{\mathrm{b}}$ Only one value obtained due to amount of sample available.

${ }^{c}$ Average of four values.

\subsection{Nonradioactive Composition of the Final Washed Sludge Batch 3 Simulant}

Provided below are the results from the analyses of the dissolved sludge slurry. The sludge slurry was dissolved via the Aqua Regia method ${ }^{6}$ and the Peroxide Fusion ${ }^{13}$ method. The same protocol was followed as described in Section 2.3.2. Dissolution results of the standard glass for the nonradioactive elemental composition were in good agreement with the known values indicating that the analytical methods were complete and performed correctly. Table 15 presents the elements including Gd (excluding oxygen) with concentrations $>0.1$ weight percent for the final washed Sludge Batch 3 simulant obtained from the ICP-ES. Table 15 also presents the standard deviation and the percent relative standard deviation in parentheses next to the weight percent value. The supernate results of the final washed Sludge Batch 3 supernate are the same as the supernate for the second wash. These results can be found in Table 10.

Table 15 - ICP-ES Results for the Final Washed Sludge Batch 3 Simulant

\begin{tabular}{|c|c|}
\hline Element $^{\mathrm{a}}$ & Wt.\% (Std. Dev., \% RSD) \\
\hline $\mathrm{Al}$ & $5.98 \mathrm{E} 00( \pm 2.7 \mathrm{E}-01,4.5 \mathrm{E} 00)$ \\
\hline $\mathrm{Ba}$ & $2.73 \mathrm{E}-01( \pm 1.1 \mathrm{E}-02,4.0 \mathrm{E} 00)$ \\
\hline $\mathrm{Ca}$ & $2.38 \mathrm{E} 00( \pm 6.9 \mathrm{E}-02,2.9 \mathrm{E} 00)$ \\
\hline $\mathrm{Cu}$ & $1.50 \mathrm{E}-01( \pm 3.0 \mathrm{E}-03,2.0 \mathrm{E} 00)$ \\
\hline $\mathrm{Fe}$ & $2.71 \mathrm{E} 01( \pm 1.5 \mathrm{E} 00,5.4 \mathrm{E} 00)$ \\
\hline $\mathrm{Gd}$ & $8.90 \mathrm{E}-02( \pm 4.7 \mathrm{E}-03,5.3 \mathrm{E} 00)$ \\
\hline $\mathrm{Mg}$ & $1.38 \mathrm{E}-01( \pm 1.7 \mathrm{E}-02,1.2 \mathrm{E} 01)$ \\
\hline $\mathrm{Mn}$ & $3.01 \mathrm{E} 00( \pm 2.2 \mathrm{E}-01,7.2 \mathrm{E} 00)$ \\
\hline $\mathrm{Na}^{\mathrm{b}}$ & $6.79 \mathrm{E} 00( \pm 2.0 \mathrm{E}-01,3.0 \mathrm{E} 00)$ \\
\hline $\mathrm{Ni}$ & $3.05 \mathrm{E} 00( \pm 1.4 \mathrm{E}-01,4.6 \mathrm{E} 00)$ \\
\hline $\mathrm{Pb}^{\mathrm{c}}$ & $1.53 \mathrm{E}-01( \pm 5.3 \mathrm{E}-03,3.5 \mathrm{E} 00)$ \\
\hline $\mathrm{Si}^{\mathrm{c}}$ & $1.06 \mathrm{E} 00( \pm 1.1 \mathrm{E}-01,1.1 \mathrm{E} 01)$ \\
\hline $\mathrm{U}^{\mathrm{b}}$ & $3.38 \mathrm{E}-01( \pm 1.5 \mathrm{E}-02,4.5 \mathrm{E} 00)$ \\
\hline $\mathrm{Zn}$ & $3.14 \mathrm{E}-01( \pm 2.7 \mathrm{E}-02,8.7 \mathrm{E} 00)$ \\
\hline
\end{tabular}

\subsection{Radioactive Composition of the Final Washed Sludge Batch 3 Simulant}

Presented below in Table 16 are the results from the ICP-MS and radioactive counting methods for the final washed Sludge Batch 3 simulant. The aqua regia dissolution solutions described in Section 3.2 were used for the ICP-MS analyses. Both dissolution solutions were used for the counting methods. The units used for the ICP-MS results and the counting methods are presented next to each value. The standard deviation and the percent relative standard deviations for the values are presented in parentheses. 


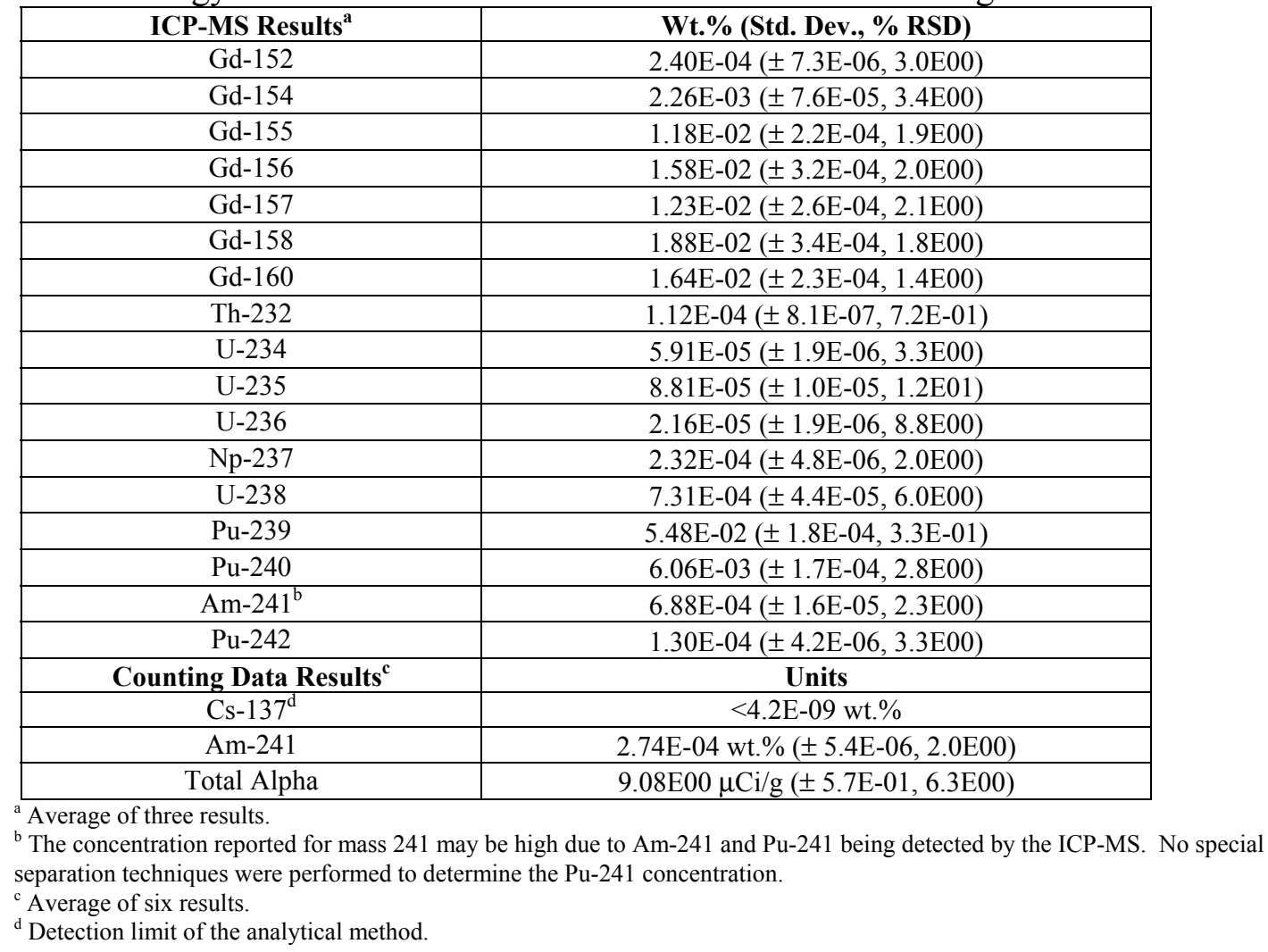

The ratio of $\mathrm{Gd}$ to $\mathrm{Pu}$ for the final washed Sludge Batch 3 Simulant can be calculated by adding up the concentrations of the $\mathrm{Gd}$ isotopes and the concentrations of the Pu isotopes in Table 16. The next step is to divide the $\mathrm{Gd}$ by the $\mathrm{Pu}$ concentration to obtain the ratio. The ratio for the final washed Sludge Batch 3 simulant is $1.27: 1$. This ratio is different from the predicted ratio of $1.40: 1^{4}$ and the calculated ratio of 1.34:1 for both washes. The differences in the ratios from the predicted ratio are reasonable, and are probably due to analytical error surrounding the measurement of the low concentrations of $\mathrm{Gd}$ and $\mathrm{Pu}$ in the sludge slurry.

\subsection{DESCRIPTION OF THE SYSTEM USED TO PERFORM THE SRAT CYCLE AND ACID CALCULATIONS FOR THE SRAT CYCLE}

As noted previously in Section 1.0, the SRAT cycle was completed to determine the behavior of the Pu and Gd during the SRAT process. Since this was the main objective of the SRAT run, no additions of noble metals (related to $\mathrm{H}_{2}$ production in the SRAT) or mercury were made to the Sludge Batch 3 simulant. These issues are specifically related to Sludge Batch 3 and will be investigated as a part of the Sludge Batch 3 nonradioactive work conducted at the ACTL, and the radioactive work conducted in the Shielded Cells facility with the Sludge Batch 3 qualification samples.

To determine the behavior of the Pu/Gd under normal operating conditions in the DWPF SRAT vessel, a SRAT product with an ending $\mathrm{pH}$ of 7 was selected. To determine the behavior of the $\mathrm{Pu} / \mathrm{Gd}$ under extreme acidic conditions in the DWPF SRAT vessel, a SRAT product with an ending $\mathrm{pH}$ of 3 was selected. For the extreme acidic condition scenario, the SRAT product with the ending $\mathrm{pH}$ of 7 was reheated and then the necessary amounts of nitric and formic acids were added to reach the ending $\mathrm{pH}$ of 3 . By testing both of these scenarios, information about the dissolution of $\mathrm{Pu} / \mathrm{Gd}$ as a function of $\mathrm{pH}$ could be obtained. To obtain the concentrations of the $\mathrm{Pu} / \mathrm{Gd}$ in the SRAT product and the SRAT product supernate for both scenarios, samples will be taken and analyzed for nonradioactive and radioactive composition. 
The sections below provide a description of the system used in the glove box to perform the SRAT cycle using the Sludge Batch 3 Simulant and the data used to calculate the amounts of nitric acid and formic acid required to complete the SRAT cycle.

\subsection{System Description}

The SRAT/SME vessel used in this confirmation run is a glass cylinder approximately 8 inches in height and 3 inches wide. The SRAT/SME vessel has a capacity of approximately 1 liter, and the top of the SRAT/SME vessel has a series of ports and openings. These ports and openings are for the installation of equipment (i.e. $\mathrm{pH}$ probe, thermocouple, agitator, purge line, etc.) and for the addition of chemicals (acids, antifoam, etc.). The condenser, mercury/condensate trap, and cold trap connected to the SRAT/SME vessel are also made out of glass.

To supply heat to the SRAT/SME vessel, a heating mantle is used. A chiller unit is used to supply the chilled water for the condenser. Since this was a solubility test, no offgas data were collected. Figure 1 is a picture taken in the glove box of the system during the SRAT run.

Figure 1 - Picture of the SRAT/SME Vessel in the Glove Box

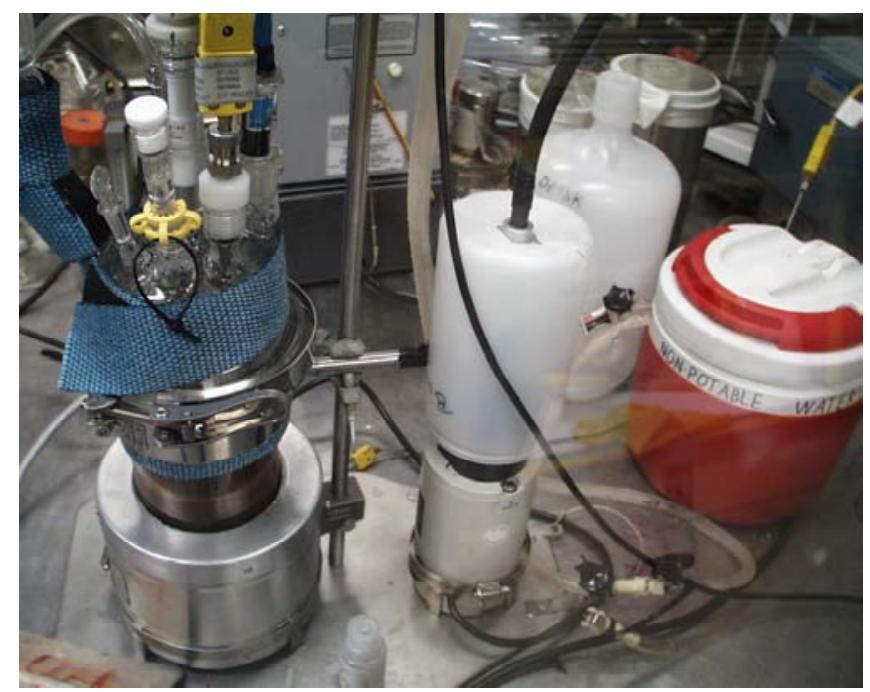

\subsection{Acid Calculations for the SRAT Cycle}

The sections below describe the analytical methods performed on the sludge slurry to obtain the remaining data in order to perform the acid calculations to determine how much nitric acid and formic acid to add for the SRAT cycle. The analytical data, presented in this section and previous sections, were entered into an Excel spreadsheet to determine the amounts of nitric and formic acids.

\subsubsection{Titration of the Washed Sludge Slurry to Obtain the Concentration of Hydroxide}

To obtain the concentration of hydroxide (in equivalents per liter $(\mathrm{Eq} / \mathrm{L})$ ) for the washed sludge slurry, a titration was completed on two portions ( $\sim 5 \mathrm{~g}$ each) of mixed sludge slurry. The first step in the procedure was to weigh each individual portion of the sludge slurry. The next step was to add a known volume of $1 \mathrm{~N}$ nitric acid to the sludge slurry. The sludge slurry was then mixed, and a $\mathrm{pH}$ recorded once the readout from the $\mathrm{pH}$ probe stabilized. The volume of nitric acid was also recorded after each addition to the sludge slurry. The titration was considered complete once the $\mathrm{pH}$ of the sludge slurry was below a $\mathrm{pH}$ of 3 . This procedure was repeated on the remaining portion of sludge slurry. The results of the titration for the two portions of sludge slurry are presented in Figure 2. Figure 2 is a graph of the $\mathrm{pH}$ of the sludge slurry (y axis) and the Eq/L of nitric acid added (x axis). Table 17 provides the data recorded for each titration. 

of Sludge Slurry vs. Eq/L of Nitric Acid Added)

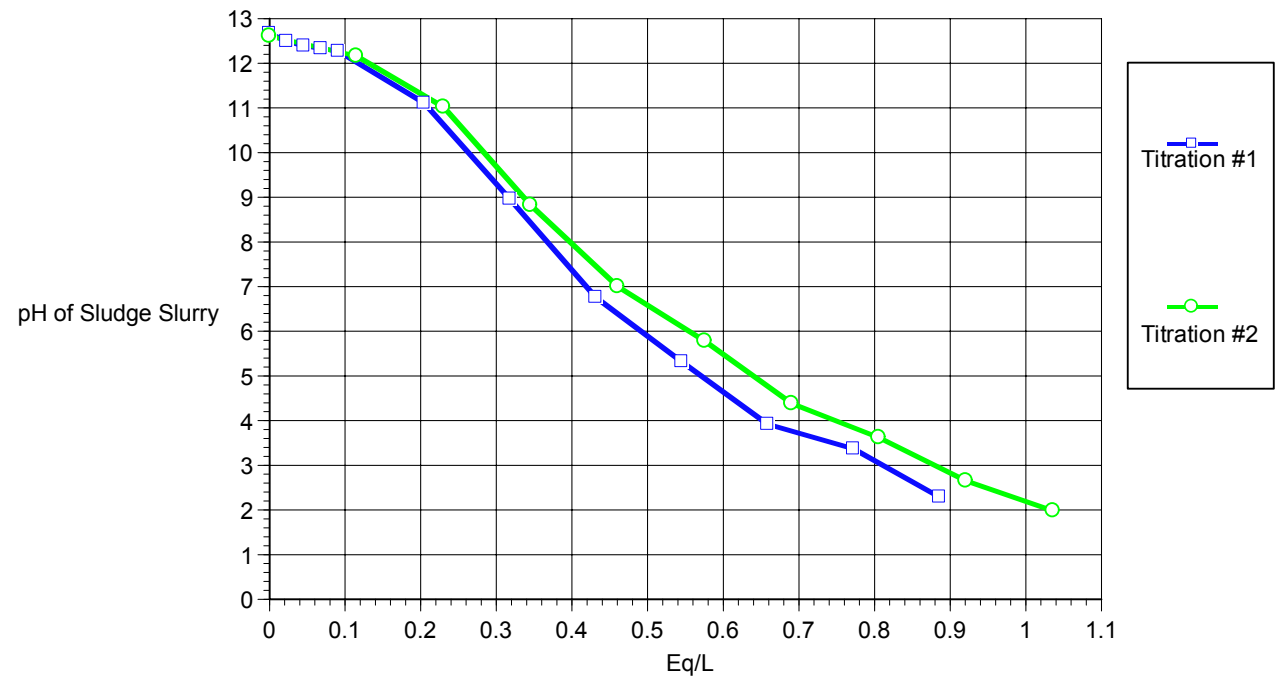

Table 17 - Titration Data for Two Samples of Washed Sludge Batch 3 Simulant

\begin{tabular}{|c|c|c|}
\hline $\begin{array}{l}\text { Titration \#1 } \\
\quad \text { Amount of Acid Added (mL) }\end{array}$ & $\mathrm{pH}$ of Sludge After Addition & $\begin{array}{r}\text { Factor for } \mathbf{E q} / \mathbf{L}=\mathbf{2 . 2 7 E - 0 1}{ }^{a} \\
\text { Eq/L Sludge Slurry }\end{array}$ \\
\hline 0 & 12.67 & $0.00 \mathrm{E}+00$ \\
\hline 0.1 & 12.49 & $2.27 \mathrm{E}-02$ \\
\hline 0.2 & 12.39 & $4.54 \mathrm{E}-02$ \\
\hline 0.3 & 12.33 & $6.81 \mathrm{E}-02$ \\
\hline 0.4 & 12.27 & $9.08 \mathrm{E}-02$ \\
\hline 0.9 & 11.11 & $2.04 \mathrm{E}-01$ \\
\hline 1.4 & 8.96 & $3.18 \mathrm{E}-01$ \\
\hline 1.9 & 6.76 & 4.32E-01 \\
\hline 2.4 & 5.32 & $5.45 \mathrm{E}-01$ \\
\hline 2.9 & 3.92 & $6.59 \mathrm{E}-01$ \\
\hline 3.4 & 3.37 & 7.72E-01 \\
\hline 3.9 & 2.29 & $8.86 \mathrm{E}-01$ \\
\hline $\begin{array}{l}\text { Titration \#2 } \\
\text { Amount of Acid Added (mL) }\end{array}$ & $\mathrm{pH}$ of Sludge After Addition & $\begin{array}{r}\text { Factor for } \mathbf{E q} / \mathbf{L}=\mathbf{2 . 3 0 E - 0 1}{ }^{\mathbf{a}} \\
\text { Eq/L Sludge Slurry }\end{array}$ \\
\hline 0 & 12.61 & $0.00 \mathrm{E}+00$ \\
\hline 0.5 & 12.16 & $1.15 \mathrm{E}-01$ \\
\hline 1.0 & 11.02 & $2.30 \mathrm{E}-01$ \\
\hline 1.5 & 8.82 & $3.45 \mathrm{E}-01$ \\
\hline 2.0 & 7.00 & 4.61E-01 \\
\hline 2.5 & 5.78 & $5.76 \mathrm{E}-01$ \\
\hline 3.0 & 4.38 & $6.91 \mathrm{E}-01$ \\
\hline 3.5 & 3.62 & $8.06 \mathrm{E}-01$ \\
\hline 4.0 & 2.65 & $9.21 \mathrm{E}-01$ \\
\hline 4.5 & 1.98 & $1.04 \mathrm{E} 00$ \\
\hline
\end{tabular}

\footnotetext{
${ }^{\mathrm{a}}$ The factor for $\mathrm{Eq} / \mathrm{L}$ is used to convert from $\mathrm{mL}$ of acid added to $\mathrm{Eq} / \mathrm{L}$ of sludge slurry.

Factor for $\mathrm{Eq} / \mathrm{L}=\frac{\text { Density of Sludge Slurry } \times \text { normality of acid }}{\text { weight of sludge slurry used in titration }}$, with the units being $\mathrm{Eq} /(\mathrm{mL}$ acid $* \mathrm{~L}$ sludge slurry $)$.
}

The differences in the titration curves could be attributed to the amount of nitric acid added and the amount of time given for the $\mathrm{pH}$ reading to stabilize prior to the $\mathrm{pH}$ being recorded. For example in titration \#1, 1.9 $\mathrm{mL}$ of nitric acid was added and a $\mathrm{pH}$ reading of 6.76 was obtained. In titration $\# 2,2.0 \mathrm{~mL}$ of nitric acid 


\subsubsection{TIC Concentration for the Washed Sludge Batch 3 Simulant}

To obtain the TIC concentration, approximately five milliliters of the mixed washed Sludge Batch 3 simulant were placed into two bottles and sent to ADS for analysis. The average of the two samples is 2745 ppm. The standard deviation is $\pm 5.0 \mathrm{E} 01$ and the percent relative standard deviation is $1.8 \mathrm{E} 00$.

An observation was made about the TIC/TOC (total inorganic carbon/total organic carbon) numbers obtained from ADS. The TOC numbers ranged from 12,080 ppm to $2540 \mathrm{ppm}$. After discussing the TOC results with ADS, it was found that the TIC and TOC determinations were not independent. The TOC number is obtained by subtracting the amount of TIC from the total carbon. It was thought at the time that the TIC numbers were valid based on the fact that they were analyzed by a different procedure than the total carbon. A request was made to repeat the analyses, but a decision was made to go forward with the SRAT cycle and Bounding test using the available TIC numbers due to project time constraints. Based on these results, any further investigation of sludge slurries containing coal warrants obtaining repetitive results for TIC/TOC.

\subsubsection{Nitric Acid and Formic Acid Results}

Samples of the nitric and formic acids used in this demonstration were submitted for analyses. The results of the analyses for the nitric acid were 10.2M (49.6 wt.\%) and the formic acid results were $22.7 \mathrm{M}(88.03$ wt.\%). The specific gravity for the nitric acid and the formic acid at the indicated molarities were 1.30 and 1.19 respectively.

\subsubsection{Acid Calculations for the SRAT Cycle}

The stoichiometric percentage used to determine the amount of nitric acid and formic acid for the glove box Cells run was $125 \%$. This percentage was selected based on previous testing completed for Sludge Batch 2. For the Sludge Batch 2 testing, a target of 125\% stoichiometry met the requirements of the list below, and also ensured the destruction of nitrite during SRAT processing.

1. Acid base neutralization reactions - destruction of hydroxides and carbonates.

2. Reaction with Sodium Nitrite - Destruction of nitrite.

3. Some reduction of $\mathrm{MnO}_{2}$ to $\mathrm{MnO}$.

4. Reduction of Mercury - This reduces $\mathrm{HgO}$ to $\mathrm{Hg}$.

5. Appropriate balance of nitric and formic for final redox in the melter.

The analytical results (located in Sections 2.0 and 4.0) for the weight percent total solids, density, hydroxide (at a pH of 7 from the titration curves, see Section 4.2.1), manganese, nitrite, mercury (no mercury in the feed), and TIC in the washed sludge slurry were entered into the spreadsheet. The results of the nitric acid and formic acid additions were also entered. Although coal was added to the Sludge Batch 3 simulant, no credit was taken for it as a reductant when targeting a value of $\mathrm{Fe}^{2+} / \mathrm{Fe}^{\mathrm{tot}}=0.2$ for melter redox. The issue of coal in the Sludge Batch 3 and how it affects the final redox in the melter will have to be addressed separately in the ACTL and Shielded Cells work for Sludge Batch 3. After entering all of the required data, the amounts of the nitric acid and formic acid were determined to be 180 gallons (DWPF basis) and 331 gallons (DWPF basis) respectively. These amounts of nitric acid and formic acid obtained from the spreadsheet were required to complete the necessary reactions and meet the redox in the melter. The volume of acids has increased compared to a prototypic amount of 90-100 gallons of nitric acid and 190-210 gallons of formic acid for Sludge Batch 2. This increase is due mainly to the TIC value. See Section 4.2.2 for more information. To scale the amounts of nitric acid and formic acid from a DWPF basis to a glove box basis, the volume of each acid was converted to milliliters and then multiplied by a value of 1.32E-5 (See Appendix A). Table 18 is a copy of the spreadsheet used to determine the amounts of nitric acid and formic acid for the glove box SRAT cycle. 
Table 18 - Excel Spreadsheet for Determining Nitric Acid and Formic Acid Requirements for the SRAT Cycle

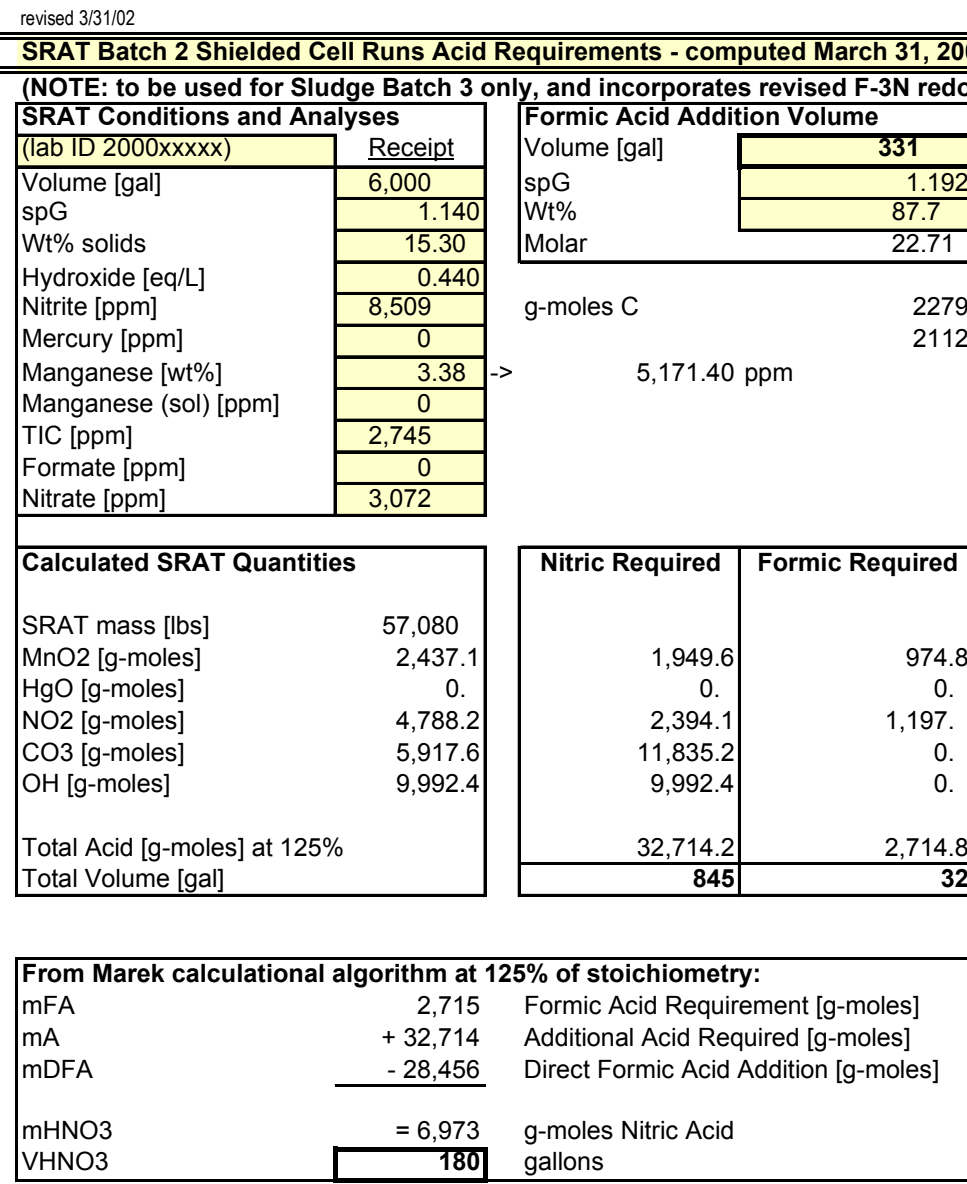

Specify the following quantities in the SRAT procedure:

180 gallons of $50 \mathrm{wt} \%$ nitric acid

331 gallons of $90 \mathrm{wt} \%$ formic acid

6,300 gallon SRAT concentration endpoint

12 hours of additional reflux

6,000 gallon SRAT reflux endpoint/final SRAT slurry level

Notes:

Adjust formic acid volume (F5) with Goal Seek function to make target glass redox (L8) $=0.2$.

Blue numbers in yellow-shaded cells indicate user input.

\begin{tabular}{|c|c|c|}
\hline \multicolumn{3}{|l|}{ Glovebox Calc } \\
\hline $\begin{array}{l}\text { NITRIC } \\
\text { FORMIC }\end{array}$ & $\begin{array}{r}682 \\
12\end{array}$ & \\
\hline $\begin{array}{l}\text { Scale Factor = } \\
\text { NITRIC } \\
\text { FORMIC }\end{array}$ & $\begin{array}{r}1.321 \mathrm{E}-05 \\
9.0112 \mathrm{~mL} \\
16.5500 \mathrm{~mL}\end{array}$ & $\begin{array}{l}11.7145 \mathrm{~g} \\
19.7276 \mathrm{~g}\end{array}$ \\
\hline
\end{tabular}




\title{
5.0 DESCRIPTION OF THE SRAT CYCLE
}

\author{
Transfer of Washed Sludge Slurry to the SRAT Vessel
}

The washed sludge slurry was mixed and approximately $300 \mathrm{~mL}$ was poured into the SRAT vessel.

Initiation - Heating and Agitation

The SRAT Cycle began on 2 April 2002 at 0640 with the start of the agitator and heating mantle. When the vessel reached $50^{\circ} \mathrm{C}(0740)$, antifoam was added. During this heating period, the agitator speed was increased because the sludge slurry appeared to be very viscous with no visible surface movement.

\section{Nitric Acid Addition}

At 0847 , vessel temperature reached $90^{\circ} \mathrm{C}$, and nitric acid addition was initiated. Based on the acid calculations (see Section 4.2.4), $9 \mathrm{~mL}$ of $50 \mathrm{wt} \%$ nitric acid was added to the vessel at the flow rate of $0.1 \mathrm{~mL} / \mathrm{min}$ (added by 500 lambda pipette every 5 minutes). The acid addition was completed by 1013. During the addition of the nitric acid, the $\mathrm{pH}$ of the sludge slurry dropped from $12.1\left(\sim 90^{\circ} \mathrm{C}\right)$ to $8.9\left(\sim 90^{\circ} \mathrm{C}\right)$. At the completion of the addition, the sludge slurry was visually examined. The surface appeared smooth but thick.

\section{Formic Acid Addition}

Prior to the start of the formic acid addition, an antifoam addition was made to the SRAT vessel. At 1030, the formic acid addition began. A total of $16.6 \mathrm{~mL}$ of $90 \mathrm{wt} \%$ formic acid (see Section 4.2.4 for acid calculations) was added at a flow rate of $0.10 \mathrm{~mL} / \mathrm{min}$ (added by 500 lambda pipette every 5 minutes). During the addition of the formic acid, the $\mathrm{pH}$ of the sludge slurry dropped from $8.9\left(\sim 90^{\circ} \mathrm{C}\right)$ to $3.0\left(\sim 90^{\circ} \mathrm{C}\right)$. The surface of the sludge slurry reacted with a rise in level (foamy bubbles) with each addition of formic acid until the pH dropped below 5. The rise in level quickly dissipated shortly after the addition. Also, as the $\mathrm{pH}$ of sludge slurry dropped, the mixing of the sludge slurry in the vessel improved. The entire surface (around the thermocouples and $\mathrm{pH}$ probe) of the sludge slurry was moving with ease and a vortex was noticed around the agitator shaft. The formic acid addition was completed at 1254 .

\section{Concentration and Reflux}

The vessel was heated to boiling to remove the volume of liquid added during the acid additions, and then to reflux for eight hours. Condensate collection (i.e. boiling) began at approximately 1319. During boiling, it was noticed that a ring of fine black particles was forming around the $400-450 \mathrm{~mL}$ mark in the SRAT vessel. The ring of black particles resembled the coal (carbon) that was initially added to the "de-washed sludge slurry". The SRAT run was terminated at 2100 with only eight hours of boiling completed.

Figure 3 is a graph of the $\mathrm{pH}$ taken during the SRAT cycle verses time. From 0850 to 1254 the SRAT $\mathrm{pH}$ dropped due to the addition of nitric and formic acids. During the eight hour boiling period, the $\mathrm{pH}$ of the SRAT product begins to slowly rise.

The vessel was reheated to boiling at 0805 the next morning, April 3, 2002. The contents of the SRAT vessel were boiled for another 4 hours to meet the DWPF 12 hour boiling requirement for the SRAT cycle. The vessel was allowed to cool and samples were taken for analyses. The ending $\mathrm{pH}$ was $3.79\left(\sim 50^{\circ} \mathrm{C}\right)$. This low $\mathrm{pH}$ can be explained by the amount of acid added during the SRAT cycle (See Section 4.2.4) and the lack of noble metals in the Sludge Batch 3 simulant. The noble metals catalytically decompose the formic acid to produce $\mathrm{CO}_{2}$ and $\mathrm{H}_{2}$.

\section{$\underline{\text { Antifoam Addition }}$}

Antifoam was added when the vessel temperature reached $50^{\circ} \mathrm{C}$, prior to formic acid addition, prior to boiling, and then every eight hours thereafter per the current DWPF antifoam strategy. 
Figure 3 - Graph of the pH Taken During the SRAT Cycle Over Time Nitric Acid Added Formic Acid Added Boiling

pH During SRAT Cycle

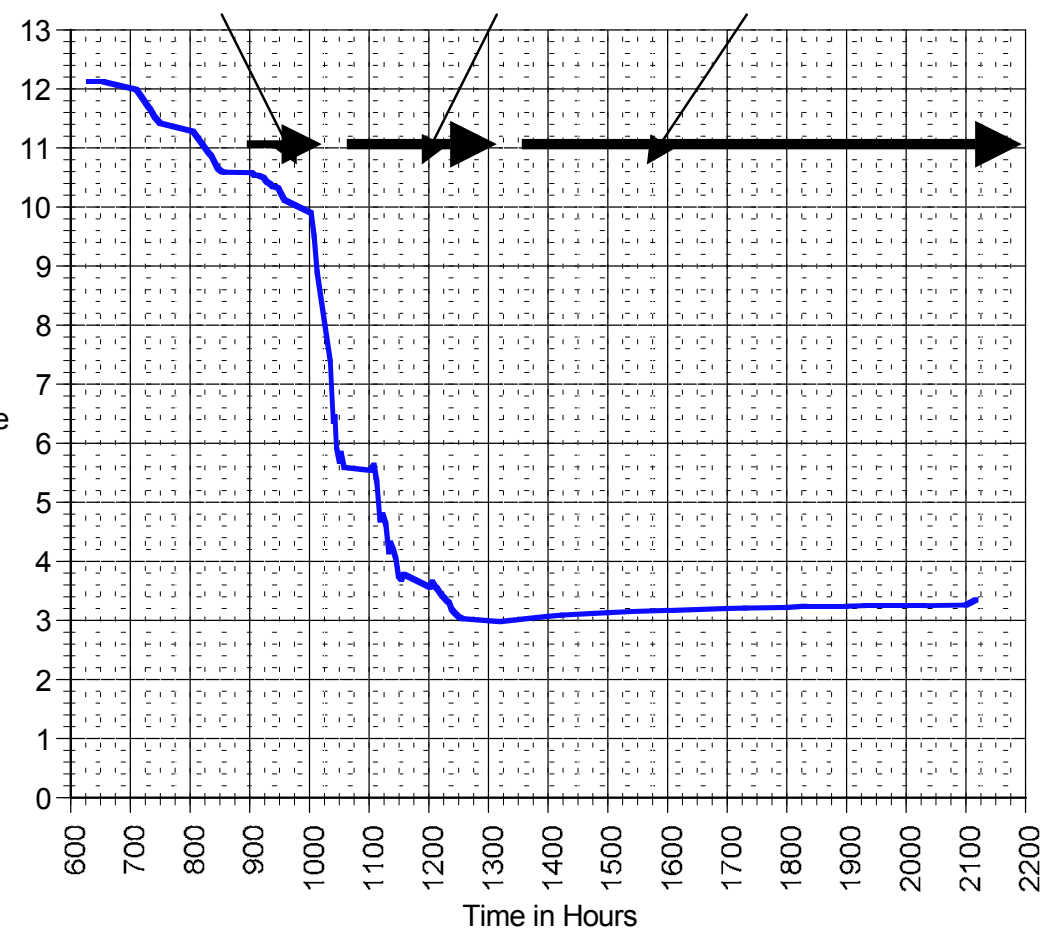

\subsection{SRAT CYCLE RESULTS}

Presented below are the results obtained from the SRAT cycle. These include the weight percent solids, density, and final composition of the SRAT product. To obtain the supernate for the required analyses, a portion of the mixed sludge slurry was filtered.

\subsection{Weight Percent Solids and Density Measurements for the SRAT Product}

Weight percent solids measurements were completed for the SRAT product and the SRAT supernate as described in Section 2.3.1. The averages of the calculated results of the weight percent solids for the sludge slurry and the supernate are presented in column two and column three of Table 19 respectively. The standard deviations (Std. Dev.) and the percent relative standard deviations (\% RSD) for the data are also presented in column two and column three of Table 19.

Density measurements were completed for the SRAT product and the SRAT supernate as described in Section 3.1. The results of the SRAT product and supernate are presented in column four and column five of Table 19. The standard deviations (Std. Dev.) and the percent relative standard deviations (\% RSD) for the data are also presented in column four and five of Table 19. 
Table 19 - Weight Percent Solids and Density Measurements for the SRAT Product

\begin{tabular}{|c|c|c|c|c|}
\hline & $\begin{array}{c}\text { Wt. \% Total Solids for } \\
\text { the SRAT Product }^{\mathbf{a}}\end{array}$ & $\begin{array}{c}\text { Wt. \% Dissolved } \\
\text { Solids for the } \\
\text { SRAT Supernate }\end{array}$ & $\begin{array}{c}\text { Density } \\
\text { Measurements for } \\
\text { the SRAT Product }^{\mathbf{b}}\end{array}$ & $\begin{array}{c}\text { Density } \\
\text { Measurements for } \\
\text { the SRAT }^{\text {Supernate }}\end{array}$ \\
\hline Average & $17.55 \mathrm{wt} . \%$ & $7.89 \mathrm{wt} \% \%$ & $1.16 \mathrm{~g} / \mathrm{mL}$ & $1.07 \mathrm{~g} / \mathrm{mL}$ \\
\hline Std. Dev. & $\pm 2.00 \mathrm{E}-01$ & $\pm 1.30 \mathrm{E}-01$ & $\pm 2.0 \mathrm{E}-03$ & $\pm 2.0 \mathrm{E}-03$ \\
\hline \%RSD & $1.14 \mathrm{E} 00$ & $1.65 \mathrm{E} 00$ & $1.4 \mathrm{E}-01$ & $1.7 \mathrm{E}-01$ \\
\hline
\end{tabular}

${ }^{a}$ Sample(s) were dried at $110^{\circ} \mathrm{C}$ overnight.

${ }^{\mathrm{b}}$ Average of four values.

\subsection{Nonradioactive Composition of the SRAT Product and the SRAT Supernate}

Provided below are the results from the analyses of the dissolved SRAT product. The SRAT product was dissolved via the Aqua Regia method ${ }^{6}$. The same protocol was followed as described in Section 2.3.2. The dissolution results of the standard glass for the nonradioactive elemental composition were in good agreement with the known values indicating that the analytical methods were complete and performed correctly. Table 20 presents the elements (excluding oxygen) with concentrations $>0.1$ weight percent for the final washed Sludge Batch 3 simulant obtained from the ICP-ES. Table 20 also presents the standard deviation and the percent relative standard deviation in parentheses next to the weight percent value.

The SRAT product was filtered to obtain the supernate (See Section 2.3.4 for details). Table 21 presents the elements with concentrations $>1 \mathrm{ppm}(\mathrm{mg} / \mathrm{L}$ of supernate) in the supernate for the SRAT supernate samples obtained from the ICP- ES and the IC. Table 21 also presents the standard deviation and the percent relative standard deviation in parentheses next to the weight percent value.

Table 20 - ICP-ES Results for the SRAT Product

\begin{tabular}{|c|c|}
\hline Element $^{\mathrm{a}}$ & Wt.\% (Std. Dev., \% RSD) \\
\hline $\mathrm{Al}$ & $5.55 \mathrm{E} 00( \pm 2.7 \mathrm{E}-02,4.8 \mathrm{E}-01)$ \\
\hline $\mathrm{Ba}$ & $2.56 \mathrm{E}-01( \pm 2.2 \mathrm{E}-03,8.5 \mathrm{E}-01)$ \\
\hline $\mathrm{Ca}$ & $2.11 \mathrm{E} 00( \pm 1.4 \mathrm{E}-02,6.7 \mathrm{E}-01)$ \\
\hline $\mathrm{Cr}$ & $1.66 \mathrm{E}-01( \pm 4.0 \mathrm{E}-03,2.4 \mathrm{E} 00)$ \\
\hline $\mathrm{Cu}$ & 1.35E-01 ( \pm 4.8E-04, 3.6E-01) \\
\hline $\mathrm{Fe}$ & $2.59 \mathrm{E} 01( \pm 1.5 \mathrm{E}-01,5.7 \mathrm{E}-01)$ \\
\hline $\mathrm{Gd}^{\mathrm{b}}$ & $9.06 \mathrm{E}-02( \pm 7.5 \mathrm{E}-04,8.3 \mathrm{E}-01)$ \\
\hline $\mathrm{Mg}$ & $1.41 \mathrm{E}-01( \pm 1.5 \mathrm{E}-03,1.0 \mathrm{E} 00)$ \\
\hline $\mathrm{Mn}$ & $2.81 \mathrm{E} 00( \pm 2.8 \mathrm{E}-02,1.0 \mathrm{E} 00)$ \\
\hline $\mathrm{Na}$ & $5.74 \mathrm{E} 00( \pm 1.5 \mathrm{E}-02,2.7 \mathrm{E}-01)$ \\
\hline $\mathrm{Ni}$ & $2.85 \mathrm{E} 00( \pm 2.0 \mathrm{E}-02,6.9 \mathrm{E}-01)$ \\
\hline $\mathrm{Pb}$ & $1.40 \mathrm{E}-01( \pm 3.3 \mathrm{E}-03,2.3 \mathrm{E} 00)$ \\
\hline $\mathrm{U}$ & $3.57 \mathrm{E}-01( \pm 9.0 \mathrm{E}-03,2.5 \mathrm{E} 00)$ \\
\hline $\mathrm{Zn}$ & $2.68 \mathrm{E}-01( \pm 7.5 \mathrm{E}-04,2.8 \mathrm{E}-01)$ \\
\hline
\end{tabular}

${ }^{a}$ Results are determined by ICP-ES and are the average of results of three samples unless otherwise indicated. The standard deviation and the percent relative standard deviation are presented in parentheses next to each value.

${ }^{\mathrm{b}} \mathrm{Gd}$ was added to the table since this is a Study of $\mathrm{Pu} / \mathrm{Gd}$ solubility during the washing process. 
Table 21 - ICP-ES and IC Results for the SRAT Supernate

\begin{tabular}{|c|c|}
\hline ICP-ES Results & SRAT Supernate ${ }^{c}$ \\
\hline $\mathrm{Al}$ & $1.08 \mathrm{E} 03 \mathrm{mg} / \mathrm{L}$ Supernate $( \pm 0,0)$ \\
\hline $\mathrm{B}$ & $2.27 \mathrm{E} 01 \mathrm{mg} / \mathrm{L}$ Supernate $( \pm 3.1 \mathrm{E}-01,1.4 \mathrm{E} 00)$ \\
\hline $\mathrm{Ba}$ & $8.57 \mathrm{E} 00 \mathrm{mg} / \mathrm{L}$ Supernate $( \pm 4.0 \mathrm{E}-02,5.0 \mathrm{E}-01)$ \\
\hline $\mathrm{Ca}$ & 4.15E03 mg/L Supernate $( \pm 4.2 \mathrm{E} 01,1.0 \mathrm{E} 00)$ \\
\hline Co & $4.13 \mathrm{E} 00 \mathrm{mg} / \mathrm{L}$ Supernate $( \pm 2.0 \mathrm{E}-02,3.8 \mathrm{E}-01)$ \\
\hline $\mathrm{Cr}$ & $5.47 \mathrm{E} 00 \mathrm{mg} / \mathrm{L}$ Supernate $( \pm 4.0 \mathrm{E}-02,6.7 \mathrm{E}-01)$ \\
\hline $\mathrm{Cu}$ & $2.56 \mathrm{E} 02 \mathrm{mg} / \mathrm{L}$ Supernate $( \pm 5.9 \mathrm{E}-01,2.3 \mathrm{E}-01)$ \\
\hline $\mathrm{Fe}$ & 1.73E02 mg/L Supernate $( \pm$ 5.7E00, 3.3E00) \\
\hline Gd & $1.70 \mathrm{E} 01 \mathrm{mg} / \mathrm{L}$ Supernate $( \pm 2.1 \mathrm{E}-01,1.2 \mathrm{E} 00)$ \\
\hline $\mathrm{La}$ & $3.36 \mathrm{E} 00 \mathrm{mg} / \mathrm{L}$ Supernate $( \pm 4.0 \mathrm{E}-01,1.2 \mathrm{E} 00)$ \\
\hline $\mathrm{Mg}$ & $3.08 \mathrm{E} 02 \mathrm{mg} / \mathrm{L}$ Supernate $( \pm 2.4 \mathrm{E} 00,7.6 \mathrm{E}-01)$ \\
\hline $\mathrm{Mn}$ & $5.72 \mathrm{E} 03 \mathrm{mg} / \mathrm{L}$ Supernate $( \pm$ 5.4E01, 9.4E-01) \\
\hline $\mathrm{Na}$ & $1.39 \mathrm{E} 04 \mathrm{mg} / \mathrm{L}$ Supernate $( \pm 0,0)$ \\
\hline $\mathrm{Ni}$ & $3.49 \mathrm{E} 03 \mathrm{mg} / \mathrm{L}$ Supernate $( \pm 2.6 \mathrm{E} 01,7.0 \mathrm{E}-01)$ \\
\hline $\mathrm{P}$ & $1.09 \mathrm{E} 01 \mathrm{mg} / \mathrm{L}$ Supernate $( \pm 1.0 \mathrm{E}-01,9.3 \mathrm{E}-00)$ \\
\hline $\mathrm{Pb}$ & $1.20 \mathrm{E} 01 \mathrm{mg} / \mathrm{L}$ Supernate $( \pm 1.0 \mathrm{E}-01,8.5 \mathrm{E}-01)$ \\
\hline $\mathrm{Si}$ & $1.50 \mathrm{E} 01 \mathrm{mg} / \mathrm{L}$ Supernate $( \pm 4.4 \mathrm{E}-01,3.0 \mathrm{E} 00)$ \\
\hline Sn & $2.15 \mathrm{E} 00 \mathrm{mg} / \mathrm{L}$ Supernate $( \pm 8.0 \mathrm{E}-02,3.6 \mathrm{E} 00)$ \\
\hline $\mathrm{Sr}$ & $1.78 \mathrm{E} 02 \mathrm{mg} / \mathrm{L}$ Supernate $( \pm 5.9 \mathrm{E}-01,3.3 \mathrm{E}-01)$ \\
\hline $\mathrm{U}$ & $1.48 \mathrm{E} 01 \mathrm{mg} / \mathrm{L}$ Supernate $( \pm 4.1 \mathrm{E}-01,2.8 \mathrm{E} 00)$ \\
\hline $\mathrm{Zn}$ & $3.42 \mathrm{E} 02 \mathrm{mg} / \mathrm{L}$ Supernate $( \pm 1.8 \mathrm{E} 00,5.2 \mathrm{E}-01)$ \\
\hline IC Results & SRAT Supernate ${ }^{c}$ \\
\hline Flouride $^{\mathrm{a}}$ & $<2 \mathrm{mg} / \mathrm{L}$ Supernate \\
\hline Formate $^{b}$ & 3.73E04 mg/L Supernate $( \pm 7.2 \mathrm{E} 01,1.9 \mathrm{E}-01)$ \\
\hline Chloride & $1.16 \mathrm{E} 03 \mathrm{mg} / \mathrm{L}$ Supernate $( \pm$ 5.9E00, 5.1E-01) \\
\hline Nitrite $^{c}$ & $<1.02 \mathrm{E} 02 \mathrm{mg} / \mathrm{L}$ Supernate \\
\hline Nitrate & 2.81E04 ( \pm 5.9E01, 2.1E-01) \\
\hline Phosphate $^{\mathrm{c}}$ & $<102 \mathrm{mg} / \mathrm{L}$ Supernate \\
\hline Sulfate & $1.15 \mathrm{E} 02 \mathrm{mg} / \mathrm{L}$ Supernate $( \pm 2.9 \mathrm{E} 01,2.6 \mathrm{E} 01)$ \\
\hline Oxalate $^{c}$ & $<102 \mathrm{mg} / \mathrm{L}$ Supernate \\
\hline
\end{tabular}

One of the requirements for the DWPF SRAT cycle is to destroy the nitrite. From Table 21, the value for nitrite is $<102 \mathrm{ppm}$. This meets the DWPF criteria of having $<1000 \mathrm{ppm}$ of nitrite at the end of the SRAT cycle.

\subsection{Radioactive Composition for the SRAT Product and SRAT Supernate}

Presented below in Table 22 are the results from the ICP-MS and radioactive counting methods for the SRAT product. The aqua regia dissolution solutions described in Section 6.2 were used for the ICP-MS analyses. The dissolution solution was used for the counting methods. The units used for the ICP-MS results and the counting methods are presented next to each value. The standard deviation and the percent relative standard deviations for the values are presented in parentheses. 
Table 22 - ICP-MS and Counting Results for the SRAT Product

\begin{tabular}{|c|c|}
\hline ICP-MS Results $^{\mathrm{a}}$ & Wt.\% (Std. Dev., \% RSD) \\
\hline Gd-152 & $2.20 \mathrm{E}-04( \pm 4.0 \mathrm{E}-06,2.0 \mathrm{E} 00)$ \\
\hline Gd-154 & $1.94 \mathrm{E}-03( \pm 3.1 \mathrm{E}-05,1.6 \mathrm{E} 00)$ \\
\hline Gd-155 & $9.70 \mathrm{E}-03( \pm 1.2 \mathrm{E}-04,1.2 \mathrm{E} 00)$ \\
\hline Gd-156 & $1.32 \mathrm{E}-02( \pm 1.8 \mathrm{E}-04,1.4 \mathrm{E} 00)$ \\
\hline Gd-157 & $1.00 \mathrm{E}-02( \pm 1.8 \mathrm{E}-04,1.8 \mathrm{E} 00)$ \\
\hline Gd-158 & $1.59 \mathrm{E}-02( \pm 2.2 \mathrm{E}-04,1.4 \mathrm{E} 00)$ \\
\hline Gd-160 & $1.38 \mathrm{E}-02( \pm 1.9 \mathrm{E}-04,1.3 \mathrm{E} 00)$ \\
\hline Th-232 & $9.22 \mathrm{E}-05( \pm 3.1 \mathrm{E}-06,3.4 \mathrm{E} 00)$ \\
\hline $\mathrm{U}-234$ & 4.42E-05( $\pm 4.2 \mathrm{E}-06,9.5 \mathrm{E} 00)$ \\
\hline $\mathrm{U}-235$ & 5.99E-05 ( $\pm 3.7 \mathrm{E}-06,6.2 \mathrm{E} 00)$ \\
\hline U-236 & $1.58 \mathrm{E}-05( \pm 1.3 \mathrm{E}-06,8.4 \mathrm{E} 00)$ \\
\hline $\mathrm{Np}-237$ & $2.03 \mathrm{E}-04( \pm 2.9 \mathrm{E}-06,1.4 \mathrm{E} 00)$ \\
\hline $\mathrm{U}-238$ & $5.53 \mathrm{E}-04( \pm 1.0 \mathrm{E}-05,1.8 \mathrm{E} 00)$ \\
\hline $\mathrm{Pu}-239$ & $5.07 \mathrm{E}-02( \pm 1.3 \mathrm{E}-03,2.5 \mathrm{E} 00)$ \\
\hline $\mathrm{Pu}-240$ & $5.28 \mathrm{E}-03( \pm 1.4 \mathrm{E}-04,2.6 \mathrm{E} 00)$ \\
\hline $\mathrm{Am}-241^{\mathrm{b}}$ & $5.96 \mathrm{E}-04( \pm 1.7 \mathrm{E}-05,2.9 \mathrm{E} 00)$ \\
\hline $\mathrm{Pu}-242$ & $1.16 \mathrm{E}-04( \pm 3.7 \mathrm{E}-06,3.2 \mathrm{E} 00)$ \\
\hline Counting Data Results ${ }^{\mathrm{a}}$ & Units \\
\hline Cs- $137^{\mathrm{c}}$ & $<1.3 \mathrm{E}-09$ wt. $\%$ \\
\hline Am-241 & $2.52 \mathrm{E}-04$ wt. $\%( \pm 2.8 \mathrm{E}-06,1.1 \mathrm{E} 00)$ \\
\hline Total Alpha & $8.90 \mathrm{E} 00 \mu \mathrm{Ci} / \mathrm{g}( \pm 2.7 \mathrm{E}-01,3.0 \mathrm{E} 00)$ \\
\hline
\end{tabular}

The ratio of Gd to Pu for the SRAT Product can be calculated by adding up the concentrations of the Gd isotopes and the concentrations of the Pu isotopes in Table 22 and then dividing Gd by the Pu. The ratio for the SRAT product is 1.16:1. This ratio is different from the expected ratio of $1.40: 1^{4}$ and the ratio of 1.27:1 for final washed Sludge Batch 3 simulant. Because of this difference, a calculation was completed to determine if the amount of $\mathrm{Gd}$ or Pu determined by ADS was causing the ratio to change. The total grams of $\mathrm{Gd}$ and $\mathrm{Pu}$ in the final washed Sludge Batch 3 Simulant were $0.0406 \mathrm{~g}$ and $0.0319 \mathrm{~g}$ (based on the volume, density, and weight percent solids of the sludge slurry) respectively. The total grams of Gd and $\mathrm{Pu}$ for the SRAT product are $0.0393 \mathrm{~g}$ and $0.0340 \mathrm{~g}$ (based on the volume, density, and the weight percent solids of the SRAT product) respectively. There was a decrease in the amount of Gd and an increase in amount of $\mathrm{Pu}$ in the SRAT product when compared to the grams of $\mathrm{Gd}$ and $\mathrm{Pu}$ determined for the final washed sludge slurry. The differences in the amount of $\mathrm{Gd}$ and $\mathrm{Pu}$ are reasonable, and are probably due to analytical error surrounding the measurement of the low concentrations of $\mathrm{Gd}$ and $\mathrm{Pu}$ in the sludge slurry.

Presented below in Table 23 are the results from the ICP-MS and radioactive counting methods for the SRAT supernate. The supernate samples obtained in Section 6.2 were used for the ICP-MS analyses and the counting methods. The units used for the ICP-MS results and the counting methods are presented next to each value. The standard deviation and the percent relative standard deviations for the values are presented in parentheses. 
Table 23 - ICP-MS and Counting Results for the SRAT Supernate

\begin{tabular}{|c|c|}
\hline ICP-MS Results $^{\mathrm{a}}$ & mg/L Supernate (Std. Dev., \% RSD) \\
\hline Gd-152 & $9.96 \mathrm{E}-03( \pm 5.8 \mathrm{E}-04,6.0 \mathrm{E} 00)$ \\
\hline Gd-154 & $8.89 \mathrm{E}-02( \pm 1.8 \mathrm{E}-03,2.0 \mathrm{E} 00)$ \\
\hline Gd-155 & $5.28 \mathrm{E}-01( \pm 1.1 \mathrm{E}-02,2.0 \mathrm{E} 00)$ \\
\hline Gd-156 & $7.31 \mathrm{E}-01( \pm 1.7 \mathrm{E}-02,2.4 \mathrm{E} 00)$ \\
\hline Gd-157 & $5.58 \mathrm{E}-01( \pm 1.2 \mathrm{E}-02,1.8 \mathrm{E} 00)$ \\
\hline Gd-158 & $8.82 \mathrm{E}-01( \pm 2.2 \mathrm{E}-02,2.5 \mathrm{E} 00)$ \\
\hline Gd-160 & $7.74 \mathrm{E}-01( \pm 1.9 \mathrm{E}-02,2.4 \mathrm{E} 00)$ \\
\hline U-233 & $8.75 \mathrm{E}-04( \pm 2.7 \mathrm{E}-05,3.1 \mathrm{E} 00)$ \\
\hline U-234 & $6.79 \mathrm{E}-02( \pm 1.8 \mathrm{E}-03,2.6 \mathrm{E} 00)$ \\
\hline $\mathrm{U}-235$ & $9.64 \mathrm{E}-02( \pm 9.8 \mathrm{E}-04,1.0 \mathrm{E} 00)$ \\
\hline U-236 & $2.63 \mathrm{E}-02( \pm 3.1 \mathrm{E}-05,1.2 \mathrm{E} 00)$ \\
\hline $\mathrm{Np}-237$ & $2.09 \mathrm{E}-02( \pm 2.2 \mathrm{E}-06,1.1 \mathrm{E} 00)$ \\
\hline U-238 & $3.58 \mathrm{E}-01( \pm 2.3 \mathrm{E}-03,6.3 \mathrm{E}-01)$ \\
\hline Pu-239 & $6.29 \mathrm{E}-02( \pm 1.5 \mathrm{E}-03,2.4 \mathrm{E} 00)$ \\
\hline $\mathrm{Pu}-240$ & $6.80 \mathrm{E}-03( \pm 4.7 \mathrm{E}-04,6.9 \mathrm{E} 00)$ \\
\hline Am-241 & $6.61 \mathrm{E}-03( \pm 1.0 \mathrm{E}-03,1.6 \mathrm{E} 01)$ \\
\hline $\mathrm{Pu}-242^{\mathrm{b}}$ & 4.17E-04 ( $\pm 1.3 \mathrm{E}-04,3.2 \mathrm{E} 01)$ \\
\hline Counting Data Results $^{\mathrm{a}}$ & Units \\
\hline Cs- $137^{b}$ & $2.73 \mathrm{E}-04 \mu \mathrm{Ci} / \mathrm{mL}$ of supernate $( \pm 2.4 \mathrm{E}-05,8.6 \mathrm{E} 00)$ \\
\hline Am-241 & $2.79 \mathrm{E}-01 \mu \mathrm{Ci} / \mathrm{mL}$ of supernate $( \pm 3.0 \mathrm{E}-02,1.1 \mathrm{E} 01)$ \\
\hline Total Alpha & $6.23 \mathrm{E} 04 \mathrm{dpm} / \mathrm{mL}$ of supernate $( \pm 3.2 \mathrm{E} 03,5.2 \mathrm{E} 00)$ \\
\hline
\end{tabular}

Using ICP-ES data from Table 20 and Table 21, the percentage of $\mathrm{Al}, \mathrm{Ca}, \mathrm{Fe}, \mathrm{Mg}$, and $\mathrm{Mn}$ that became soluble during the SRAT cycle can be determined. Using the ICP-MS data from and Table 23, the percentage of $\mathrm{Gd}$ and $\mathrm{Pu}$ that became soluble during the SRAT cycle can be determined. Table 24 presents the grams of $\mathrm{Al}, \mathrm{Ca}, \mathrm{Fe}, \mathrm{Mg}, \mathrm{Mn}, \mathrm{Gd}$, and $\mathrm{Pu}$ that were soluble after the completion of the SRAT process. These values are presented on a sludge slurry basis.

Table 24 - Amount of Al, Ca, Fe, Mg, Mn, Gd, and Pu Soluble After the SRAT Cycle

\begin{tabular}{|c|c|c|c|c|}
\hline \multirow[t]{10}{*}{ SRAT Cycle ${ }^{\mathrm{a}}$} & Element & $\begin{array}{l}\text { Grams in the Dried } \\
\text { SRAT Product }\end{array}$ & $\begin{array}{c}\text { Grams in the } \\
\text { Supernate on a } \\
\text { Sludge Slurry Basis }\end{array}$ & \% Soluble \\
\hline & $\mathrm{Al}$ & $3.37 \mathrm{E} 00$ & $3.14 \mathrm{E}-01$ & $9.30 \%$ \\
\hline & $\mathrm{Ca}$ & $1.28 \mathrm{E} 00$ & $1.21 \mathrm{E} 00$ & $94 \%$ \\
\hline & $\mathrm{Fe}$ & $1.57 \mathrm{E} 01$ & $5.03 \mathrm{E}-02$ & $0.32 \%$ \\
\hline & $\mathrm{Mg}$ & $8.58 \mathrm{E}-02$ & $8.98 \mathrm{E}-02$ & $105 \%$ \\
\hline & $\mathrm{Mn}$ & $1.71 \mathrm{E} 00$ & $1.66 \mathrm{E} 00$ & $97 \%$ \\
\hline & $\mathrm{Gd}$ & $3.94 \mathrm{E}-02$ & $1.04 \mathrm{E}-03$ & $2.64 \%$ \\
\hline & $\mathrm{Pu}-239$ & $3.08 \mathrm{E}-02$ & $1.83 \mathrm{E}-05$ & $0.06 \%$ \\
\hline & $\mathrm{Pu}-240$ & $3.21 \mathrm{E}-03$ & $1.98 \mathrm{E}-06$ & $0.06 \%$ \\
\hline & $\mathrm{Pu}-242$ & 7.05E-05 & $1.21 \mathrm{E}-07$ & $0.17 \%$ \\
\hline
\end{tabular}

${ }^{\mathrm{a}}$ Assumptions: Total volume of $300 \mathrm{~mL}, 17.5 \mathrm{wt} . \%$ total solids, slurry density $1.155 \mathrm{~g} / \mathrm{mL}, 7.89 \mathrm{wt} . \%$ dissolved solids, and $1.07 \mathrm{~g} / \mathrm{mL}$ supernate density

From Table 24, it appears that essentially all of the $\mathrm{Mg}$, $\mathrm{Mn}$, and $\mathrm{Ca}$ was soluble at a $\mathrm{pH}$ of 3.79. A small percentage of the $\mathrm{Al}$ and $\mathrm{Gd}$ were soluble and very little of the $\mathrm{Fe}$ or $\mathrm{Pu}$ was soluble at this $\mathrm{pH}$. This indicates that the majority of the Pu was insoluble along with the Fe and Gd. It also appeared, from Table 24, that more of the $\mathrm{Gd}$ was dissolved than the Pu. As a well mixed slurry in the DWPF, there is enough $\mathrm{Fe}$ with the fissile Pu to not cause a criticality concern (i.e. Fe:Pu ratio must be greater than $160: 1^{14}$ ). No experimental data was obtained for a settled SRAT product to prove the $\mathrm{Pu}$ (from the $\mathrm{Pu} / \mathrm{Gd}$ mixture) does not preferentially settle if the agitation in the DWPF SRAT vessel was stopped. A calculation is being 
performed to prove that the $\mathrm{Pu}$ does not preferentially settle and that the Fe and other neutron poisons in the settled sludge are sufficient to prevent a criticality if agitation were stopped.

The fractions for the Pu isotopes in Table 24 should agree, but they do not. The likely reason for the higher solubility of the Pu-242 is analytical error surrounding the ICP-MS method.

\subsection{LOWERING OF THE PH OF THE SRAT PRODUCT TO 3}

After the SRAT cycle was completed and the samples were taken, the vessel was heated again and the $\mathrm{pH}$ was lowered to $\sim 3$. This was completed in order to study the $\mathrm{Pu} / \mathrm{Gd}$ mixture under very acidic conditions in the SRAT vessel. Table 25 provides the amount of acid to be added to lower the $\mathrm{pH}$ to 3 . The same input variables were used as in except for the TIC value and the total $\mathrm{OH}^{-}$. The total $\mathrm{OH}^{-}$was obtained from Figure 2, and the TIC value used is an average of four values. The nitric acid and the formic acid values in Table 25 were subtracted from the values in to obtain the amount of nitric acid and formic acid needed for addition. Presented below are the results from this experiment.

\subsection{Description of the pH 3 SRAT Cycle}

Initiation - Heating and Agitation

The SRAT Cycle began on 4 April 2002 at 0615 with the start of the agitator and heating mantle. When the vessel reached $50^{\circ} \mathrm{C}(0740)$, antifoam was added. The sludge slurry surface appeared to be well mixed with a lot of surface movement.

\section{Nitric Acid Addition}

At 0802 , vessel temperature was at $90^{\circ} \mathrm{C}$, and nitric acid addition was initiated. Based on the acid calculations (see Section 4.2.4 and Section 7.0), $2 \mathrm{~mL}$ of $50 \mathrm{wt} \%$ nitric acid was added to the vessel at the flow rate of 0.1 $\mathrm{mL} / \mathrm{min}$ (added by 500 lambda pipette every 5 minutes). The acid addition was completed by 0824 . During the addition of the nitric acid, the $\mathrm{pH}$ of the sludge slurry dropped from $3.90\left(\sim 25^{\circ} \mathrm{C}\right)$ to $3.12\left(\sim 90^{\circ} \mathrm{C}\right)$. At the completion of the addition, the sludge slurry was visually examined. The surface appeared smooth with a lot of surface movement.

\section{Formic Acid Addition}

Prior to the start of the formic acid addition an antifoam addition was made to the SRAT vessel. At 0832, the formic acid addition began. A total of $3.7 \mathrm{~mL}$ of $90 \mathrm{wt} \%$ formic acid (see Section 4.2.4 and Section 7.0 for acid calculations) was added at a flow rate of $0.10 \mathrm{~mL} / \mathrm{min}$ (added by 500 lambda pipette every 5 minutes). During the addition of the formic acid, the $\mathrm{pH}$ of the sludge slurry dropped from $3.12\left(\sim 90^{\circ} \mathrm{C}\right)$ to $2.76\left(\sim 90^{\circ} \mathrm{C}\right)$. The formic acid addition was completed at 0902 .

\section{Concentration and Reflux}

The vessel was heated to boiling to remove the volume of liquid added during the acid additions, and then to reflux for twelve hours. Condensate collection (i.e. boiling) began at approximately 0935 . Two extra additions of antifoam were made during the 12 hour boiling period due to foaming in the vessel. It is believed that the excess acid in the vessel may be consuming the antifoam or rendering it ineffective over time. The SRAT cycle was complete 213004 April 2002. Figure 4 presents the $\mathrm{pH}$ for the SRAT cycle over time. From 0807 to 0902 the SRAT $\mathrm{pH}$ dropped due to the addition of nitric and formic acids. During the twelve hour boiling period, the $\mathrm{pH}$ of the SRAT product begins to slowly rise.

All of the sludge slurry was transferred from the SRAT vessel to sample bottles for analyses the next day (4/5/2002). After transferring the sludge slurry out of the SRAT vessel, the bottom of the vessel was inspected for solids. White solids in the form of several small clumps $(\sim 1 \mathrm{~mm})$ were found on the bottom of the vessel. These solids appeared to be coated with sludge slurry. See Figure 5 for a picture of the white solids (coated with sludge slurry). There is evidence (see Section 7.5) that at least a portion of these white clumps coated with sludge slurry 
were the sand that had been added to the initial "de-washed' sludge slurry. Samples of these solids were obtained and submitted for analyses. Also, samples of the SRAT product were pulled for analyses to assess the chemical behavior of the $\mathrm{Pu} / \mathrm{Gd}$ mixture in the sludge slurry.

Table 25 - Excel Spreadsheet for Determining Nitric Acid and Formic Acid Requirements to Lower the pH of the SRAT Product to 3

revised $3 / 31 / 02$

\begin{tabular}{|c|c|}
\hline \multicolumn{2}{|c|}{ SRAT Batch 2 Shielded Cell Runs Acid } \\
\hline \multicolumn{2}{|c|}{$\begin{array}{l}\text { (NOTE: to be used for Sludge Batch } 3 \text { c } \\
\text { SRAT Conditions and Analyses }\end{array}$} \\
\hline$(\operatorname{lab} I D 2000 x \times x \times x)$ & Receipt \\
\hline \multirow{3}{*}{$\begin{array}{l}\text { Volume [gal] } \\
\text { spG } \\
\text { Wt\% solids }\end{array}$} & 6,000 \\
\hline & 1.140 \\
\hline & 15.30 \\
\hline & 0.846 \\
\hline & 8,509 \\
\hline Mercury $[\mathrm{ppm}]$ & 0 \\
\hline \multirow{3}{*}{$\begin{array}{l}\text { Manganese [wt\%] } \\
\text { Manganese (sol) [ppm] } \\
\text { TIC [ppm] }\end{array}$} & 3.38 \\
\hline & 0 \\
\hline & 2,048 \\
\hline \multirow{2}{*}{$\begin{array}{l}\text { Formate }[\mathrm{ppm}] \\
\text { Nitrate }[\mathrm{ppm}]\end{array}$} & 0 \\
\hline & 3,072 \\
\hline \multicolumn{2}{|c|}{ Calculated SRAT Quantities } \\
\hline SRAT mass [lbs] & 57,080 \\
\hline MnO2 [g-moles] & $2,437.1$ \\
\hline $\begin{array}{l}\mathrm{HgO}[\mathrm{g}-\mathrm{moles}] \\
\mathrm{NO} 2[\mathrm{~g}-\mathrm{moles}]\end{array}$ & $\begin{array}{c}0 . \\
4.788 .2\end{array}$ \\
\hline CO3 [g-moles] & 4,415 \\
\hline $\mathrm{OH}[\mathrm{g}-\mathrm{moles}]$ & $19,212.7$ \\
\hline \multicolumn{2}{|c|}{$\begin{array}{l}\text { Total Acid [g-moles] at } 125 \% \\
\text { Total Volume [gal] }\end{array}$} \\
\hline
\end{tabular}

\section{equirements - computed March 31, 2001 By T.L. \\ Formic Acid Addition Volum}

Volume [gal]

spG

W $t \%$

Molar

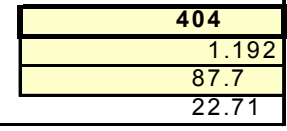

g-moles C

2279

$2112 \mathrm{ppm}$

$5,171.40 \mathrm{ppm}$

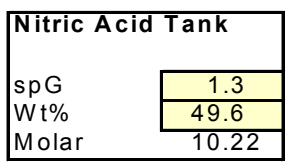

4558

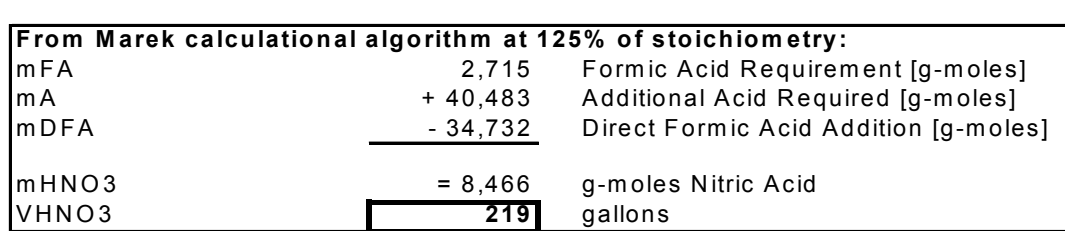

Specify the following quantities in the SRAT procedure:

219 gallons of 50 wt $\%$ nitric acid

404 gallons of $90 \mathrm{wt} \%$ formic acid

6,300 gallon SRAT concentration endpoint

12 hours of additional reflux

6,000 gallon SRAT reflux endpoint/final SRAT slurry level

Notes:

Adjust formic acid volume (F5) with Goal Seek function to make target glass redox (L8) $=0.2$.

Blue numbers in yellow-shaded cells indicate user input.

\begin{tabular}{|c|c|c|}
\hline Glovebox Calc & & \\
\hline $\begin{array}{l}\text { NITRIC } \\
\text { FORMIC }\end{array}$ & 828 & $\begin{array}{l}\mathrm{L} \\
\mathrm{L}\end{array}$ \\
\hline $\begin{array}{l}\text { Scale Factor = } \\
\text { NITRIC } \\
\text { FORMIC }\end{array}$ & $\begin{array}{r}1.321 \mathrm{E}-05 \\
10.9407 \mathrm{~mL} \\
20.2000 \mathrm{~mL}\end{array}$ & $\begin{array}{l}14.2229 \mathrm{~g} \\
24.0784 \mathrm{~g}\end{array}$ \\
\hline
\end{tabular}


Figure 4 - Graph of the pH Taken During the SRAT Cycle (pH 3) Over Time

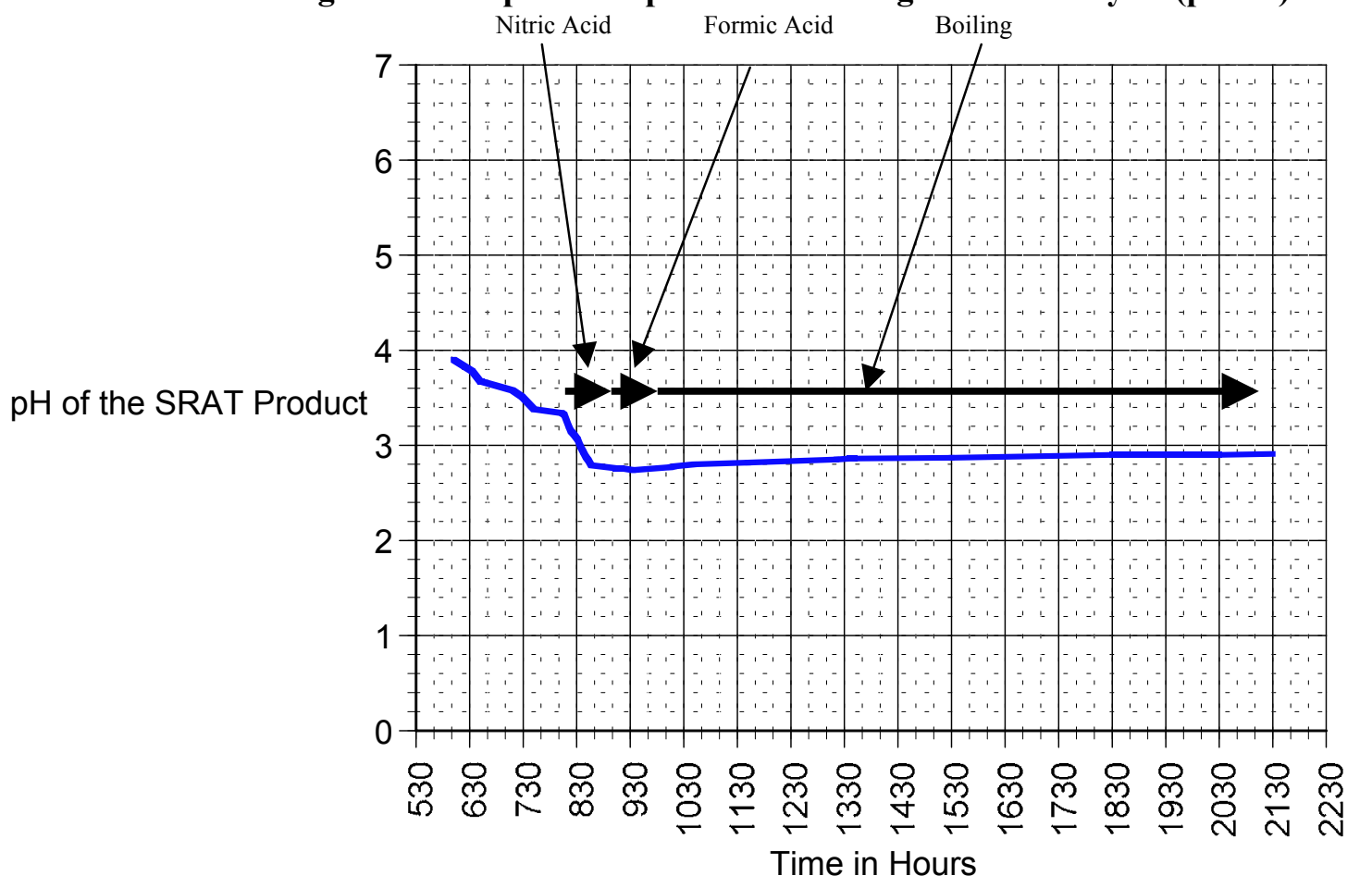

Figure 5 - Picture of the White Solids (Coated with Sludge Slurry) Found on the Bottom of the SRAT Vessel

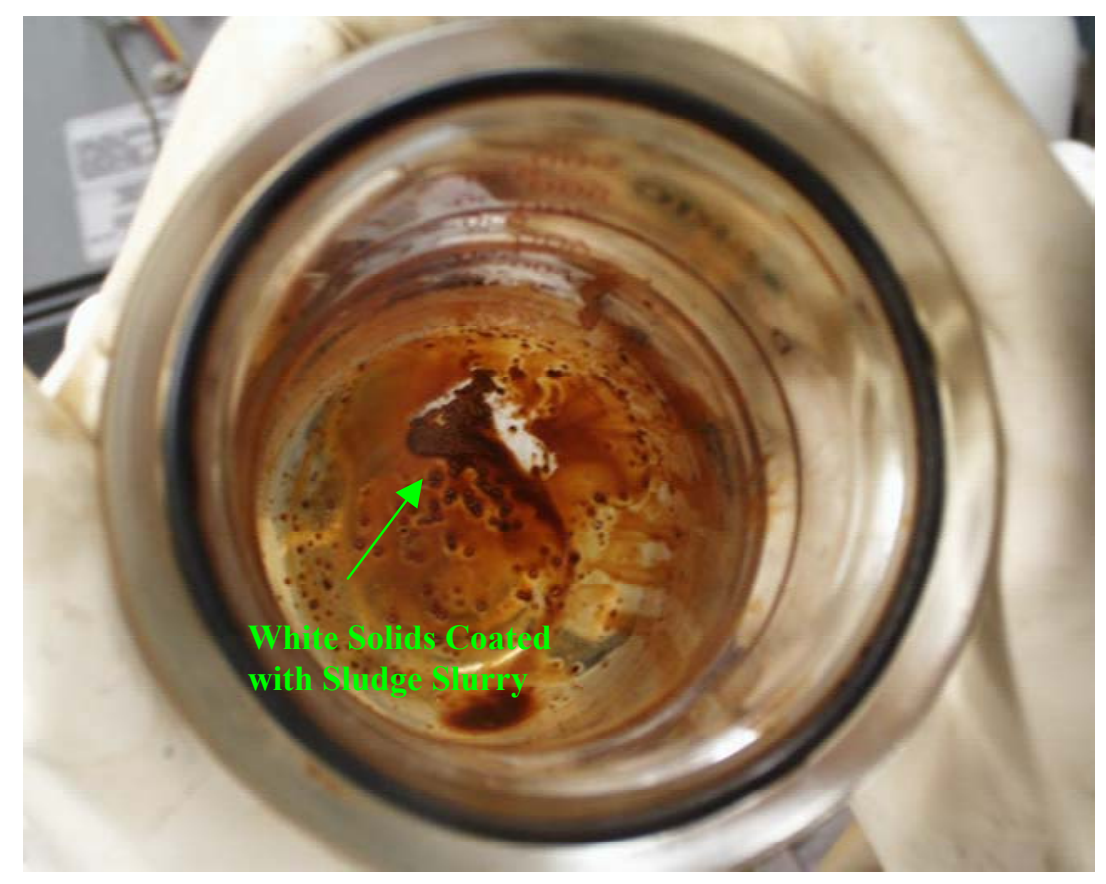




\subsection{Weight Percent Solids and Density Results for the pH 3 SRAT Product}

Weight percent solids measurements were completed for the SRAT product and the SRAT supernate as described in Section 6.1. The averages of the calculated results of the weight percent solids for the sludge slurry and the supernate are presented in column two and column three of Table 26 respectively. The standard deviations (Std. Dev.) and the percent relative standard deviations (\% RSD) for the data are also presented in column two and column three of Table 26.

Density measurements were completed for the SRAT product and the SRAT supernate as described in Section 6.1. The results of the SRAT product and SRAT supernate are presented in column four and column five of Table 26. The standard deviations (Std. Dev.) and the percent relative standard deviations (\% RSD) for the data are also presented in column four and column five of Table 26.

Table 26- Weight Percent Solids and Density Measurements for the SRAT Product (pH of $\sim 3$ )

\begin{tabular}{|c|c|c|c|c|}
\hline & $\begin{array}{c}\text { Wt. \% Total Solids for } \\
\text { the SRAT Product }\end{array}$ & $\begin{array}{c}\text { Wt. \% Dissolved } \\
\text { Solids for the SRAT } \\
\text { Supernate }\end{array}$ & $\begin{array}{c}\text { Density } \\
\text { Measurements for } \\
\text { the SRAT Product }^{\mathbf{b}}\end{array}$ & $\begin{array}{c}\text { Density } \\
\text { Measurements for } \\
\text { the SRAT } \\
\text { Supernate }\end{array}$ \\
\hline Average & $17.29 \mathrm{wt.}^{\mathbf{b}} \%$ & $7.67 \mathrm{wt.} \%$ & $1.16 \mathrm{~g} / \mathrm{mL}$ & $1.07 \mathrm{~g} / \mathrm{mL}$ \\
\hline Std. Dev. & $\pm 2.38 \mathrm{E}-01$ & $\pm 2.06 \mathrm{E}-01$ & $\pm 4.0 \mathrm{E}-03$ & $\pm 2.0 \mathrm{E}-03$ \\
\hline \%RSD & $1.38 \mathrm{E} 00$ & $2.69 \mathrm{E} 00$ & $3.8 \mathrm{E}-01$ & $1.8 \mathrm{E}-01$ \\
\hline
\end{tabular}

${ }^{a}$ Sample(s) were dried at $110^{\circ} \mathrm{C}$ overnight.

${ }^{\mathrm{b}}$ Average of four values.

\subsection{Nonradioactive Composition of the SRAT Product and the SRAT Supernate}

Provided below are the results from the analyses of the dissolved SRAT product. The SRAT product was dissolved via the Aqua Regia method ${ }^{6}$ and Sodium Peroxide Fusion method ${ }^{12}$. The same protocol was followed as described in Section 3.2. The dissolution results of the standard glass for the nonradioactive elemental composition were in good agreement with the known values indicating that the analytical methods were complete and performed correctly. Table 27 presents the elements (excluding oxygen) with concentrations $>0.1$ weight percent for the final washed Sludge Batch 3 simulant obtained from the ICP-ES. Table 27 also presents the standard deviation and the percent relative standard deviation in parentheses next to the weight percent value.

The SRAT product was filtered to obtain the supernate (See Section 2.3.4 for details). Table 28 presents the elements with concentrations $>1 \mathrm{ppm}(\mathrm{mg} / \mathrm{L}$ of supernate) in the supernate for the SRAT supernate samples obtained from the ICP- ES and the IC. Table 28 also presents the standard deviation and the percent relative standard deviation in parentheses next to the weight percent value. 
Table 27 - ICP-ES Results for the SRAT Product (pH of 3)

\begin{tabular}{|c|c|}
\hline Element $^{\text {a }}$ & Wt.\% (Std. Dev., \% RSD) \\
\hline $\mathrm{Al}$ & $5.27 \mathrm{E} 00( \pm 2.9 \mathrm{E}-01,5.4 \mathrm{E} 00)$ \\
\hline $\mathrm{Ba}$ & $2.44 \mathrm{E}-01( \pm 1.2 \mathrm{E}-02,4.9 \mathrm{E} 00)$ \\
\hline $\mathrm{Ca}$ & $2.09 \mathrm{E} 00( \pm 5.4 \mathrm{E}-02,2.6 \mathrm{E} 00)$ \\
\hline $\mathrm{Cr}$ & $1.73 \mathrm{E}-01( \pm 6.7 \mathrm{E}-02,3.9 \mathrm{E} 00)$ \\
\hline $\mathrm{Cu}$ & $1.34 \mathrm{E}-01( \pm 3.9 \mathrm{E}-03,2.9 \mathrm{E} 00)$ \\
\hline $\mathrm{Fe}$ & $2.38 \mathrm{E} 01( \pm 1.3 \mathrm{E} 00,5.6 \mathrm{E} 00)$ \\
\hline $\mathrm{Gd}$ & $7.79 \mathrm{E}-02( \pm 3.8 \mathrm{E}-03,4.9 \mathrm{E} 00)$ \\
\hline $\mathrm{Mg}$ & $1.22 \mathrm{E}-01( \pm 1.5 \mathrm{E}-02,1.3 \mathrm{E} 01)$ \\
\hline $\mathrm{Mn}$ & $2.63 \mathrm{E} 00( \pm 1.9 \mathrm{E}-01,7.8 \mathrm{E} 00)$ \\
\hline $\mathrm{Na}$ & $5.99 \mathrm{E} 00( \pm 1.2 \mathrm{E}-01,2.0 \mathrm{E} 00)$ \\
\hline $\mathrm{Ni}$ & $2.71 \mathrm{E} 00( \pm 1.5 \mathrm{E}-01,5.4 \mathrm{E}-01)$ \\
\hline $\mathrm{Pb}$ & $1.33 \mathrm{E}-01( \pm 5.5 \mathrm{E}-03,4.1 \mathrm{E} 00)$ \\
\hline $\mathrm{U}$ & $2.89 \mathrm{E}-01( \pm 3.1 \mathrm{E}-02,1.1 \mathrm{E} 01)$ \\
\hline $\mathrm{Zn}$ & $2.82 \mathrm{E}-01( \pm 2.4 \mathrm{E}-02,8.6 \mathrm{E} 00)$ \\
\hline
\end{tabular}

${ }^{a}$ Results are determined by ICP-ES and are the average of results of six samples unless otherwise indicated. The standard deviation and the percent relative standard deviation are presented in parentheses next to each value.

${ }^{b} \mathrm{Gd}$ was added to the table since this is a Study of $\mathrm{Pu} / \mathrm{Gd}$ solubility during the washing process.

${ }^{c}$ Average of three values.

Table 28 - ICP-ES and IC Results for the SRAT Supernate (pH of $\sim 3$ )

\begin{tabular}{|c|c|}
\hline ICP-ES Results & $\begin{array}{c}\text { SRAT Supernate } \\
\text { b }\end{array}$ \\
\hline $\mathrm{Al}$ & $2.14 \mathrm{E} 03 \mathrm{mg} / \mathrm{L}$ Supernate $( \pm 2.1 \mathrm{E} 01,9.7 \mathrm{E}-01)$ \\
\hline $\mathrm{B}$ & $2.02 \mathrm{E} 01 \mathrm{mg} / \mathrm{L}$ Supernate $( \pm 2.6 \mathrm{E}-01,1.3 \mathrm{E} 00)$ \\
\hline $\mathrm{Ba}$ & $6.05 \mathrm{E} 00 \mathrm{mg} / \mathrm{L}$ Supernate $( \pm 3.0 \mathrm{E}-02,5.0 \mathrm{E}-01)$ \\
\hline $\mathrm{Ca}$ & $3.70 \mathrm{E} 03 \mathrm{mg} / \mathrm{L}$ Supernate $( \pm 4.0 \mathrm{E} 01,1.1 \mathrm{E} 00)$ \\
\hline $\mathrm{Co}$ & $3.71 \mathrm{E} 00 \mathrm{mg} / \mathrm{L}$ Supernate $( \pm 2.0 \mathrm{E}-02,5.6 \mathrm{E}-01)$ \\
\hline $\mathrm{Cr}$ & $5.09 \mathrm{E} 00 \mathrm{mg} / \mathrm{L}$ Supernate $( \pm 6.0 \mathrm{E}-02,1.2 \mathrm{E} 00)$ \\
\hline $\mathrm{Cu}$ & $2.65 \mathrm{E} 02 \mathrm{mg} / \mathrm{L}$ Supernate $( \pm 1.2 \mathrm{E} 00,4.4 \mathrm{E}-01)$ \\
\hline $\mathrm{Fe}$ & 4.43E02 mg/L Supernate $( \pm 3.1 \mathrm{E} 00,6.9 \mathrm{E}-01)$ \\
\hline Gd & $1.82 \mathrm{E} 01 \mathrm{mg} / \mathrm{L}$ Supernate $( \pm 1.5 \mathrm{E}-01,8.4 \mathrm{E}-01)$ \\
\hline $\mathrm{La}$ & $3.06 \mathrm{E} 00 \mathrm{mg} / \mathrm{L}$ Supernate $( \pm 7.0 \mathrm{E}-02,2.2 \mathrm{E} 00)$ \\
\hline $\mathrm{Mg}$ & $2.75 \mathrm{E} 02 \mathrm{mg} / \mathrm{L}$ Supernate $( \pm 1.7 \mathrm{E} 00,6.3 \mathrm{E}-01)$ \\
\hline $\mathrm{Mn}$ & $4.60 \mathrm{E} 03 \mathrm{mg} / \mathrm{L}$ Supernate $( \pm 5.1 \mathrm{E} 01,1.1 \mathrm{E} 00)$ \\
\hline $\mathrm{Na}$ & $1.26 \mathrm{E} 04 \mathrm{mg} / \mathrm{L}$ Supernate $( \pm 1.7 \mathrm{E} 02,1.4 \mathrm{E} 00)$ \\
\hline $\mathrm{Ni}$ & $3.33 \mathrm{E} 03 \mathrm{mg} / \mathrm{L}$ Supernate $( \pm 3.2 \mathrm{E} 01,9.6 \mathrm{E}-01)$ \\
\hline $\mathrm{P}$ & 9.98E00 mg/L Supernate $( \pm$ 5.0E-02, 4.6E-01) \\
\hline $\mathrm{Pb}$ & $2.01 \mathrm{E} 01 \mathrm{mg} / \mathrm{L}$ Supernate $( \pm 1.0 \mathrm{E}-01,5.0 \mathrm{E}-01)$ \\
\hline $\mathrm{Si}$ & $2.0 \mathrm{E} 01 \mathrm{mg} / \mathrm{L}$ Supernate $( \pm 1.2 \mathrm{E}-01,5.8 \mathrm{E}-01)$ \\
\hline Sn & $3.19 \mathrm{E} 00 \mathrm{mg} / \mathrm{L}$ Supernate $( \pm 1.2 \mathrm{E}-01,3.6 \mathrm{E} 00)$ \\
\hline $\mathrm{Sr}$ & $1.56 \mathrm{E} 02 \mathrm{mg} / \mathrm{L}$ Supernate $( \pm 5.8 \mathrm{E}-01,3.7 \mathrm{E}-01)$ \\
\hline $\mathrm{U}$ & $1.78 \mathrm{E} 01 \mathrm{mg} / \mathrm{L}$ Supernate $( \pm 3.0 \mathrm{E}-01,1.7 \mathrm{E} 00)$ \\
\hline $\mathrm{Zn}$ & $3.46 \mathrm{E} 02 \mathrm{mg} / \mathrm{L}$ Supernate $( \pm 1.8 \mathrm{E} 00,5.2 \mathrm{E}-01)$ \\
\hline IC Results & SRAT Supernate \\
\hline Flouride $^{\mathrm{a}}$ & $<20 \mathrm{mg} / \mathrm{L}$ Supernate \\
\hline Formate & $4.36 \mathrm{E} 04 \mathrm{mg} / \mathrm{L}$ Supernate $( \pm 1.02 \mathrm{E} 02,2.0 \mathrm{E} 00)$ \\
\hline Chloride & $1.18 \mathrm{E} 03 \mathrm{mg} / \mathrm{L}$ Supernate $( \pm 1.1 \mathrm{E} 02,9.0 \mathrm{E} 00)$ \\
\hline Nitrite $^{\mathrm{a}}$ & $<1.0 \mathrm{E} 01 \mathrm{mg} / \mathrm{L}$ Supernate \\
\hline Nitrate & $2.94 \mathrm{E} 04( \pm 9.5 \mathrm{E} 02,3.2 \mathrm{E} 00)$ \\
\hline Phosphate $^{\mathrm{a}}$ & $<1.0 \mathrm{E} 01 \mathrm{mg} / \mathrm{L}$ Supernate \\
\hline Sulfate & $1.20 \mathrm{E} 02 \mathrm{mg} / \mathrm{L}$ Supernate $( \pm 0 \mathrm{E} 00,0 \mathrm{E} 00)$ \\
\hline Oxalate $^{\mathrm{a}}$ & $<1.0 \mathrm{E} 01 \mathrm{mg} / \mathrm{L}$ Supernate \\
\hline
\end{tabular}




\subsection{Radioactive Composition for the SRAT Product and SRAT Supernate}

Presented below in Table 29 are the results from the ICP-MS and radioactive counting methods for the SRAT product. The aqua regia dissolution solutions described in Section 7.3 were used for the ICP-MS analyses. Both dissolution solutions were used for the counting methods. The units used for the ICP-MS results and the counting methods are presented next to each value. The standard deviation and the percent relative standard deviations for the values are presented in parentheses.

Table 29 - ICP-MS and Counting Results for the SRAT Product (pH 3)

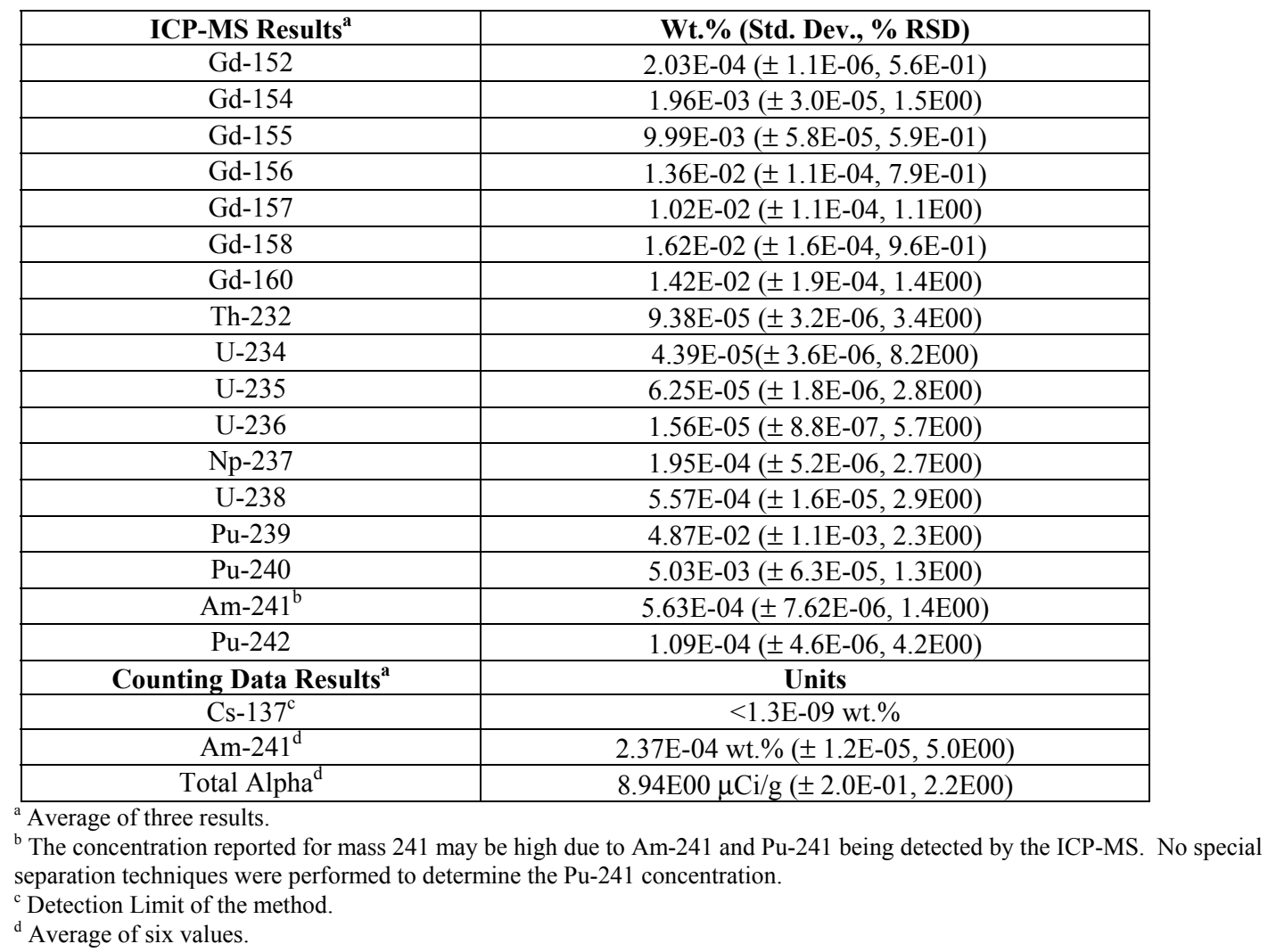

The ratio of $\mathrm{Gd}$ to $\mathrm{Pu}$ for the SRAT Product can be calculated by adding up the concentrations of the Gd isotopes and the concentrations of the Pu isotopes in Table 29 and then dividing $\mathrm{Gd}$ by the Pu. The ratio for the SRAT product is 1.23:1. This ratio is different from the expected ratio of 1.40:1 and is between the ratio of 1.27:1 for final washed Sludge Batch 3 simulant and the ratio of the first SRAT product of 1.16:1. As noted earlier in this document, the difference in the $\mathrm{Gd} / \mathrm{Pu}$ ratios can be explained by the analytical error surrounding both the $\mathrm{Gd}$ and $\mathrm{Pu}$ values.

Presented below in Table 30 are the results from the ICP-MS and radioactive counting methods for the SRAT supernate. The supernate samples obtained in Section 7.3 were used for the ICP-MS analyses and the counting methods. The units used for the ICP-MS results and the counting methods are presented next to each value. The standard deviation and the percent relative standard deviations for the values are presented in parentheses. 
Table 30 - ICP-MS and Counting Results for the SRAT Supernate (pH 3)

\begin{tabular}{|c|c|}
\hline ICP-MS Results $^{\mathrm{a}}$ & mg/L Supernate (Std. Dev., \% RSD) \\
\hline Gd-152 & $1.54 \mathrm{E}-02( \pm 7.6 \mathrm{E}-04,5.0 \mathrm{E} 00)$ \\
\hline Gd-154 & $1.56 \mathrm{E}-01( \pm 9.0 \mathrm{E}-04,5.7 \mathrm{E}-01)$ \\
\hline Gd-155 & $9.79 \mathrm{E}-01( \pm 6.3 \mathrm{E}-03,6.4 \mathrm{E}-01)$ \\
\hline Gd-156 & $1.38 \mathrm{E} 00( \pm 1.9 \mathrm{E}-02,1.4 \mathrm{E} 00)$ \\
\hline Gd-157 & $1.03 \mathrm{E} 00( \pm 6.9 \mathrm{E}-03,6.7 \mathrm{E}-01)$ \\
\hline Gd-158 & $1.64 \mathrm{E} 00( \pm 1.5 \mathrm{E}-02,9.4 \mathrm{E}-01)$ \\
\hline Gd-160 & $1.43 \mathrm{E} 00( \pm 7.3 \mathrm{E}-03,5.1 \mathrm{E}-01)$ \\
\hline $\mathrm{U}-233^{\mathrm{b}}$ & $1.37 \mathrm{E}-03( \pm 1.5 \mathrm{E}-04,1.1 \mathrm{E} 01)$ \\
\hline U-234 & $6.77 \mathrm{E}-02( \pm 3.4 \mathrm{E}-03,5.0 \mathrm{E} 00)$ \\
\hline $\mathrm{U}-235$ & $9.61 \mathrm{E}-02( \pm 2.2 \mathrm{E}-03,2.3 \mathrm{E} 00)$ \\
\hline U-236 & $2.53 \mathrm{E}-02( \pm 6.6 \mathrm{E}-04,2.6 \mathrm{E} 00)$ \\
\hline $\mathrm{Np}-237$ & $1.15 \mathrm{E}-02( \pm 1.2 \mathrm{E}-03,1.0 \mathrm{E} 01)$ \\
\hline U-238 & $3.94 \mathrm{E}-01( \pm 2.2 \mathrm{E}-03,5.6 \mathrm{E}-01)$ \\
\hline $\mathrm{Pu}-239$ & $1.50 \mathrm{E}-01( \pm 7.0 \mathrm{E}-03,4.6 \mathrm{E} 00)$ \\
\hline $\mathrm{Pu}-240$ & $1.33 \mathrm{E}-02( \pm 9.2 \mathrm{E}-04,7.0 \mathrm{E} 00)$ \\
\hline $\mathrm{Am}-241$ & $1.23 \mathrm{E}-02( \pm 3.4 \mathrm{E}-04,2.8 \mathrm{E} 00)$ \\
\hline Counting Data Results $^{\mathrm{a}}$ & Units \\
\hline Cs-137 & $2.71 \mathrm{E}-04 \mu \mathrm{Ci} / \mathrm{mL}$ of supernate $( \pm 3.7 \mathrm{E}-05,1.4 \mathrm{E} 01)$ \\
\hline Am-241 & $3.96 \mathrm{E}-01 \mu \mathrm{Ci} / \mathrm{mL}$ of supernate $( \pm 7.0 \mathrm{E}-03,1.7 \mathrm{E} 00)$ \\
\hline Total Alpha & $1.62 \mathrm{E} 05 \mathrm{dpm} / \mathrm{mL}$ of supernate $( \pm 1.4 \mathrm{E} 04,8.6 \mathrm{E} 00)$ \\
\hline
\end{tabular}

Using ICP-ES data from Table 27 and Table 28, the percentage of $\mathrm{Al}, \mathrm{Ca}, \mathrm{Fe}, \mathrm{Mg}$, and $\mathrm{Mn}$ that became soluble during the second SRAT cycle can be determined. Using the ICP-MS data from Table 29 and Table 30, the percentage of $\mathrm{Gd}$ and $\mathrm{Pu}$ that became soluble during the SRAT cycle can be determined. Table 31 presents the grams of $\mathrm{Al}, \mathrm{Ca}, \mathrm{Fe}, \mathrm{Mg}, \mathrm{Mn}, \mathrm{Gd}$, and Pu that were soluble after the completion of the SRAT process. These values are presented on a sludge slurry basis.

Table 31 - Amount of Al, Ca, Fe, Mg, Mn, Gd, and Pu Soluble After the SRAT Cycle (pH 3)

\begin{tabular}{|c|c|c|c|c|}
\hline \multirow{3}{*}{ SRAT Cycle } & Element & $\begin{array}{c}\text { Grams in the Dried } \\
\text { SRAT Product }\end{array}$ & $\begin{array}{c}\text { Grams in the } \\
\text { Supernate on a } \\
\text { Sludge Slurry Basis }\end{array}$ & \% Soluble \\
& & $2.59 \mathrm{E} 00$ & $5.09 \mathrm{E}-01$ & $19.7 \%$ \\
\cline { 2 - 5 } & $\mathrm{Al}$ & $1.03 \mathrm{E} 00$ & $8.82 \mathrm{E}-01$ & $85.9 \%$ \\
\cline { 2 - 5 } & $\mathrm{Ca}$ & $1.17 \mathrm{E} 01$ & $1.06 \mathrm{E}-01$ & $0.90 \%$ \\
\cline { 2 - 5 } & $\mathrm{Fe}$ & $5.99 \mathrm{E}-02$ & $6.55 \mathrm{E}-02$ & $84.8 \%$ \\
\cline { 2 - 5 } & $\mathrm{Mg}$ & $1.29 \mathrm{E} 00$ & $1.10 \mathrm{E} 00$ & $4.84 \%$ \\
\cline { 2 - 5 } & $\mathrm{Mn}$ & $2.26 \mathrm{E}-02$ & $3.57 \mathrm{E}-03$ & $0.15 \%$ \\
\hline
\end{tabular}

a Assumptions: Total volume of $245 \mathrm{~mL}, 17.3 \mathrm{wt} . \%$ total solids, slurry density $1.16 \mathrm{~g} / \mathrm{mL}, 7.67 \mathrm{wt} \%$ dissolved solids, and $1.07 \mathrm{~g} / \mathrm{mL}$ supernate density

From Table 31, it appears the majority of the $\mathrm{Mg}, \mathrm{Mn}$, and $\mathrm{Ca}$ was soluble at a $\mathrm{pH}$ of 3.2. A small percentage of the $\mathrm{Al}$ and $\mathrm{Gd}$ were soluble and very little of the $\mathrm{Fe}$ or $\mathrm{Pu}$ was soluble at this $\mathrm{pH}$. This would indicate that the majority of the Pu was insoluble along with the Fe and Gd. Upon comparing the results in Table 24 to Table 31 it appears that more of the $\mathrm{Gd}$ and $\mathrm{Pu}$ became soluble as the $\mathrm{pH}$ was lowered to 3. The results also indicate that more Gd is soluble than Pu. As a well mixed slurry in the DWPF, there is enough Fe with the fissile Pu to not cause a criticality concern (i.e. Fe:Pu ratio must be greater than $160: 1^{13}$ ). The ratio of Fe:Pu for this experiment was 442:1, which exceeds the ratio of 160:1. No experimental data was obtained for a settled SRAT product to prove the $\mathrm{Pu}$ (from the $\mathrm{Pu} / \mathrm{Gd}$ mixture) does not preferentially settle if the agitation in the DWPF SRAT vessel was stopped. A calculation is being performed to prove that the Pu does not preferentially settle and that the $\mathrm{Fe}$ and other neutron poisons in the settled sludge are sufficient to prevent a criticality if agitation were stopped. 
There are slight differences in the solubility of the $\mathrm{Pu}-239$ versus $\mathrm{Pu}-240$. This is contributed error surrounding the ICP-MS method rather than an isotope effect.

\subsection{Analytical Results of the Black Ring and White Solids (Coated with Sludge Slurry) Found in the SRAT Vessel}

Several samples of the black ring and white solids were taken from the SRAT vessel for analysis by X-Ray Diffraction (XRD) and Contained Scanning Electron Microscopy (CSEM). The CSEM results of the coated white solids showed that the solids were mainly a sludge slurry matrix (Fe, Na, Al, Ni, Zr etc.) with $\mathrm{Si}$. No Pu was detected in the samples of the solids submitted for analyses.

The CSEM cannot detect carbon, but a sample of the black ring was submitted to make sure no Pu was in the black ring. The results of the CSEM for that sample showed a sludge slurry matrix with no Pu detected in the sample. The XRD results of the black ring and white solids showed that the solids were mainly sand (Quartz $\left.\mathrm{SiO}_{2}\right)$, Calcite $\left(\mathrm{CaCO}_{3}\right)$, and Copper Formate $\left(\mathrm{Cu}\left(\mathrm{CHO}_{2}\right)_{2}\right)$. No carbon and no $\mathrm{Pu}$ were detected in the sample.

\subsection{SUMMARY OF THE SRAT TESTING}

The first SRAT cycle was completed with no significant processing problems noted. An ending $\mathrm{pH}$ of 7 was targeted for the first SRAT cycle, but $\mathrm{pH}$ of $3.9\left(\sim 25^{\circ} \mathrm{C}\right)$ was obtained. The lower $\mathrm{pH}$ can be explained by the amount of acid added during the SRAT cycle (See Section 4.2.4) and the lack of noble metals in the Sludge Batch 3 simulant. The noble metals catalytically decompose the formic acid to produce $\mathrm{CO}_{2}$ and $\mathrm{H}_{2}$. Although the $\mathrm{pH}$ was lower than expected, the amount of Gd and Pu dissolved, as noted in Table 24, was small and the majority of the $\mathrm{Pu}(99.9 \%)$ and $\mathrm{Gd}(97 \%)$ remained insoluble.

The second SRAT cycle was completed with no significant processing problems noted. Two extra additions of antifoam were made during the 12 hour boiling period due to foaming in the vessel. It was believed that the excess acid in the vessel may be consuming the antifoam or rendering it ineffective over time. An ending $\mathrm{pH}$ of 3 was targeted for the second SRAT cycle, but $\mathrm{pH}$ of $3.2\left(\sim 25^{\circ} \mathrm{C}\right)$ was obtained. It was noticed that there was a small increase in the amount of $\mathrm{Gd}$ and $\mathrm{Pu}$ dissolved from the sludge solids, as noted in Table 31 , but the majority of the $\mathrm{Pu}(99.8 \%)$ and $\mathrm{Gd}(95 \%)$ remained insoluble. Table 32 compares the fractions of elements soluble after the SRAT process for both SRAT products. 
Table 32 - Fraction of Selected Elements Soluble After the First SRAT Cycle and the Second SRAT Cycle

\begin{tabular}{|c|c|c|c|}
\hline \multirow[t]{10}{*}{ First SRAT Cycle $^{\text {a }}(\mathrm{ph} \sim 3.9)$} & Element & $\%$ Soluble in the Supernate & \% Insoluble in the Sludge Solids \\
\hline & $\mathrm{Al}$ & $9.30 \%$ & $90.7 \%$ \\
\hline & $\mathrm{Ca}$ & $94 \%$ & $6 \%$ \\
\hline & $\mathrm{Fe}$ & $0.32 \%$ & $99.68 \%$ \\
\hline & $\mathrm{Mg}$ & $105 \%$ & - \\
\hline & $\mathrm{Mn}$ & $97 \%$ & $3 \%$ \\
\hline & $\mathrm{Gd}$ & $2.64 \%$ & $97.36 \%$ \\
\hline & $\mathrm{Pu}-239$ & $0.06 \%$ & $99.94 \%$ \\
\hline & $\mathrm{Pu}-240$ & $0.06 \%$ & $99.94 \%$ \\
\hline & $\mathrm{Pu}-242$ & $0.17 \%$ & $99.83 \%$ \\
\hline \multirow[t]{8}{*}{ Second SRAT Cycle $^{\mathrm{b}}(\mathrm{ph} \sim 3.2)$} & $\mathrm{Al}$ & $19.7 \%$ & $80.3 \%$ \\
\hline & $\mathrm{Ca}$ & $85.9 \%$ & $14.1 \%$ \\
\hline & $\mathrm{Fe}$ & $0.90 \%$ & $99.1 \%$ \\
\hline & $\mathrm{Mg}$ & $109 \%$ & - \\
\hline & $\mathrm{Mn}$ & $84.8 \%$ & $15.2 \%$ \\
\hline & $\mathrm{Gd}$ & $4.84 \%$ & $95.16 \%$ \\
\hline & $\mathrm{Pu}-239$ & $0.15 \%$ & $99.85 \%$ \\
\hline & $\mathrm{Pu}-240$ & $0.13 \%$ & $99.87 \%$ \\
\hline
\end{tabular}

${ }^{a}$ Assumptions: Total volume of $300 \mathrm{~mL}, 17.5 \mathrm{wt} . \%$ total solids, slurry density $1.155 \mathrm{~g} / \mathrm{mL}, 7.89 \mathrm{wt} . \%$ dissolved solids, and $1.07 \mathrm{~g} / \mathrm{mL}$ supernate density.

${ }^{\mathrm{b}}$ Assumptions: Total volume of $245 \mathrm{~mL}, 17.3 \mathrm{wt} . \%$ total solids, slurry density $1.16 \mathrm{~g} / \mathrm{mL}, 7.67 \mathrm{wt} . \%$ dissolved solids, and $1.07 \mathrm{~g} / \mathrm{mL}$ supernate density

The fractions in Table 32, were then compared to a previous study ${ }^{15}$ conducted with Tank 51 radioactive sludge slurry. Figure 6 is a graph of the results obtained from a dissolution study with Tank 51 sludge slurry and nitric acid. The results in Table 32 essentially agree with the fractions at a $\mathrm{pH}$ of 3.9 and 3.2 in Figure 6.

\section{Figure 6 - Graph of pH Versus Elemental Fraction Dissolved During Nitric Acid Addition for Tank 51} Sludge Slurry

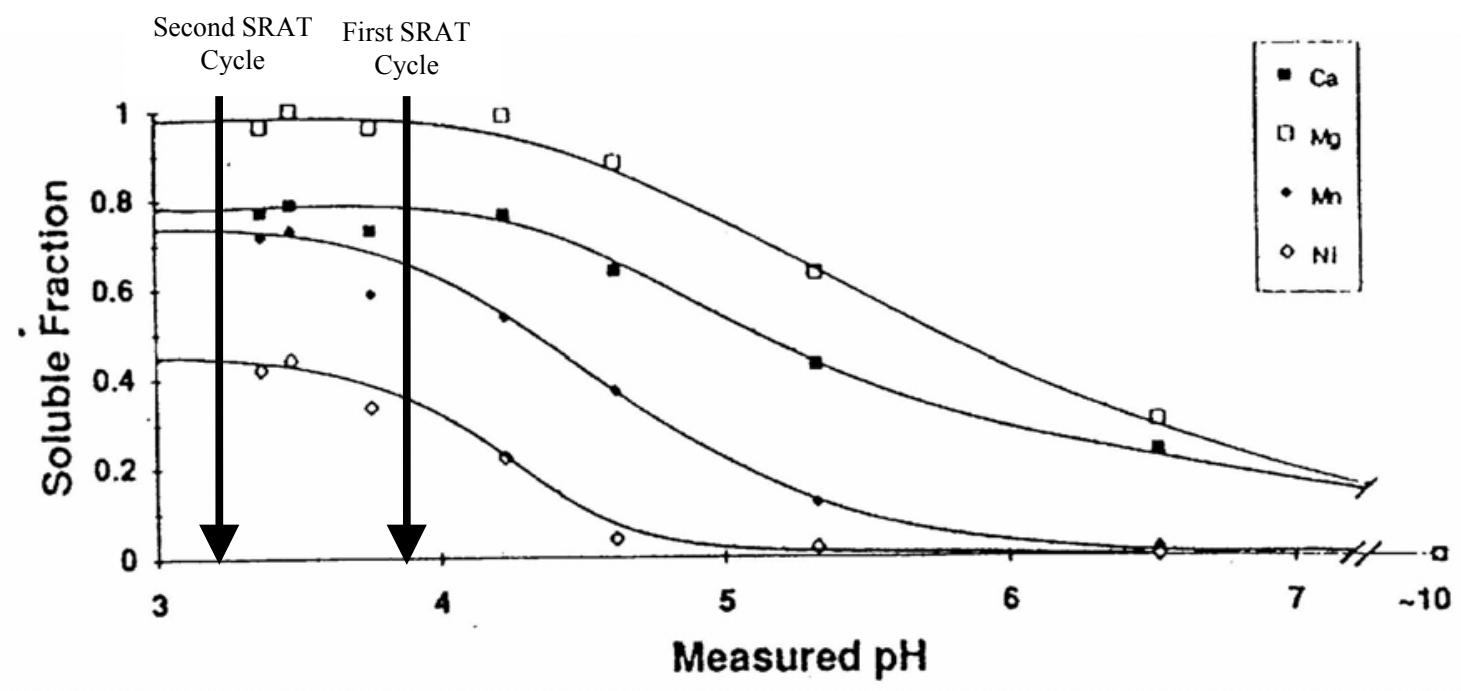

As a well mixed slurry in the DWPF (for both SRAT scenarios studied in this experiment), there is enough Fe with the fissile Pu to not cause a criticality concern (i.e. Fe:Pu ratio must be greater than $160: 1^{13}$ ). The ratio of $\mathrm{Fe}: \mathrm{Pu}$ for the first SRAT cycle and second SRAT cycle was 446:1 and 442:1 respectively. These ratios exceed the required ratio of 160:1 that is documented in DWPF criticality safety analysis summary report for sludge only operations (WSRC-RP-94-1132 ${ }^{13}$ ). No experimental data was obtained for a settled SRAT product to determine if the $\mathrm{Pu}$ (from the $\mathrm{Pu} / \mathrm{Gd}$ mixture) preferentially settles if the agitation in the DWPF SRAT vessel was stopped. The issue of preferential settling of $\mathrm{Pu}$ has been addressed in a separate memo ${ }^{16}$. 
From performing these SRAT cycles, some issues that are specific to Sludge Batch 3 have been identified. They are listed below, and should be addressed as part of the nonradioactive work conducted at the ACTL and radioactive work conducted in the Shielded Cells for Sludge Batch 3.

1. Resolve the issues surrounding the method of determining TIC/TOC for the sludge slurries that have coal added to them. The TIC concentration is an input for the acid calculations for the SRAT cycle. The TOC concentration will affect the final redox of the melter $\left(\mathrm{Fe}^{2+} / \mathrm{Fe}^{\text {tot }}\right)$ which directly affects the amount of formic acid added during the SRAT cycle.

2. Revise the spreadsheet for the SRAT acid calculations to incorporate sludge slurries that have coal/carbon in them.

3. Resolve the differences observed between the Gd concentrations obtained from the radioactive ICP-ES versus the concentrations obtained from the radioactive ICP-MS. The Gd values from the ICP-ES appeared to be biased high by $20 \%$.

4. Determine if coal/carbon ring forms above the sludge slurry for the nonradioactive and radioactive Sludge Batch 3 testing. If coal/carbon remains behind in the vessel, it could impact the ability to reliably predict the redox of the glass.

5. Determine if sand is observed on the bottom of the SRAT vessel for the nonradioactive scoping SRAT runs. Should also determine if the particle size of the sand is too large for the sampling system used in DWPF.

6. Verify the Fe to fissile material in the washed sludge slurry and the SRAT product is greater than 160:1 for the radioactive testing in the Shielded Cells.

7. Analyze the supernate at the end of the SRAT cycle to determine what species have dissolve from the sludge solids.

\subsection{CONCLUSIONS}

- Up to $0.95 \%$ of the Gd and $0.20 \%$ of the Pu was soluble during the glove box demonstration of the Tank Farm Washing Process. The majority of the $\mathrm{Gd}(99 \%)$ and $\mathrm{Pu}(99.8 \%)$ were insoluble and stayed with the sludge solids.

- The small quantities of leached plutonium during the sludge washing tests do not present a criticality safety concern and are not sufficient to adversely impact the Effluent Treatment Facility or Saltstone operations.

- No significant problems were encountered during the washing process. Based on analytical results, the $\mathrm{Pu} / \mathrm{Gd}$ mixture appeared to be uniformly distributed throughout the sludge.

- Approximately $2.64 \%$ of the $\mathrm{Gd}$ and $\sim 0.16 \%$ of the Pu was soluble after the glove box demonstration of the DWPF SRAT cycle. The majority of the Gd (97\%) and Pu (99.8\%) was insoluble and stayed with the sludge solids.

- No significant processing problems were encountered during the processing of this material through the first of two SRAT cycles.

- The nitrite was less than $102 \mathrm{ppm}$ at the end of the SRAT cycle. The DWPF requirement is $<1000 \mathrm{ppm}$ at the end of the SRAT cycle.

- $\quad$ Upon lowering the $\mathrm{pH}$ of the SRAT product to $\sim 3$, the fractions soluble were approximately $4.84 \%$ of the Gd and $0.15 \%$ of the Pu was soluble after the glove box demonstration of the DWPF SRAT cycle. The majority of the $\mathrm{Gd}(95 \%)$ and $\mathrm{Pu}(99.8 \%)$ was still insoluble and stayed with the sludge solids.

- Two extra additions of antifoam were made during the 12 hour boiling period of the second SRAT cycle ( $\mathrm{pH} \sim 3$ ) to control foaming.

- As a well mixed slurry in the DWPF (for both SRAT scenarios studied in this experiment), there is enough Fe with the fissile Pu to not cause a criticality concern (i.e. Fe:Pu ratio must be greater than 160:1). 


\subsection{APPENDIX A}

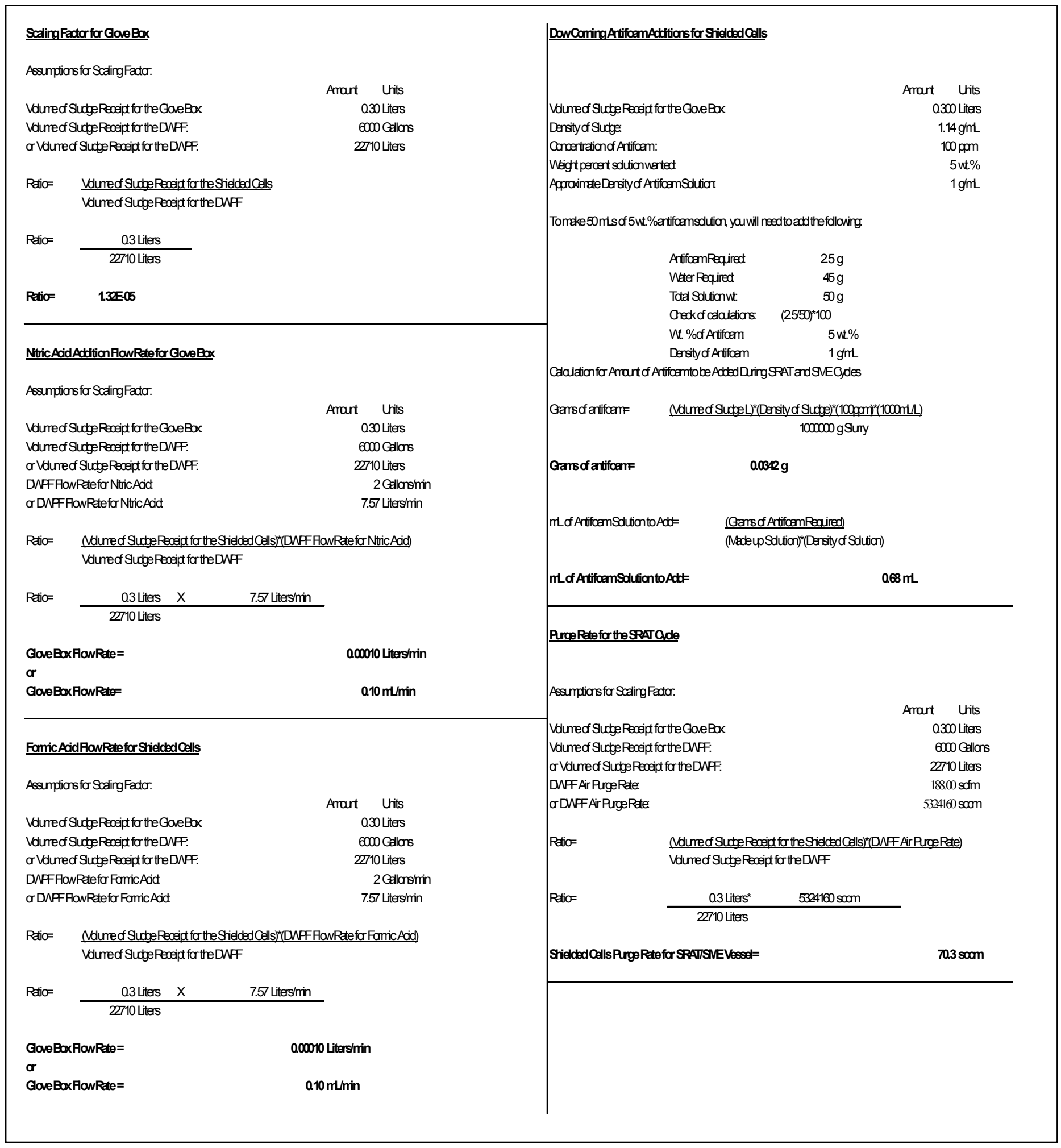




\subsection{REFERENCES}

${ }^{1}$ I.A. Jilani, Technical Task Request, TTR- NMMD-HTS-2002-010, 1/24/2002.

${ }^{2}$ T.L. Fellinger, et. "Technical Task and Quality Assurance Plan for Assessing Downstream Effects of Plutonium/Gadolinium in Sludge Washing and SRAT (U)", WSRC-RP-2002-00178, March 6, 2002.

${ }^{3}$ T.L. Fellinger, M. G. Bronikowski, and W.R. Wilmarth, "Analytical Study Plan for Assessing Downstream Effects of Plutonium/Gadolinium in Sludge Washing and SRAT (U) - Ref. TTR NMMD-HTS-2002-010", SRTGPD-2002-00034, March 12, 2002.

${ }^{4}$ M. Bronikowski, J. H. Gray, B. C. Hill, F. R. Graham, and D. G. Karraker, "Caustic Precipitation of Plutonium using Gadolinium as the Neutron Poison for Disposition to High Level Waste", WSRC-TR-2002-00198, May 2, 2002.

${ }^{5}$ D.K. Peeler, N.E. Bibler, and T.B. Edwards, “An Assessment of the Impacts of Adding Pu/Gd and Am/Cm Waste Streams to Sludge Batch 3 (SB3) on DWPF $\mathrm{H}_{2}$ Generation rates and Glass Properties (U)", WSRC-TR2002-00145, To Be Published.

${ }^{6}$ C.J. Coleman, “Aqua Regia Dissolution of Sludge for Elemental Analysis (U)”, ADS Procedure, ADS-2226, Rev.0, May 1990.

${ }^{7}$ Private Correspondence (telephone conversation) with H.Elder, 3/19/2002.

${ }^{8}$ H.H. Elder, "Engineering Position Paper - Impact of Processing Americium and Curium in ESP, DWPF, and Saltstone (U)" HLW-SDT-2001-00244, Rev.1.

9 "Safety Analysis - 200 Area/Savannah River Plant/Separation Area/Operations/Liquid Radioactive Waste Handling Facilities, DPSTSA-200-10, Sup-18, August 1988.

10 "Procedure WAC 4.02 F/H Effluent Treatment Facility Waste Acceptance Criteria", WSRC Procedure Manual 1S SRS - Waste Acceptance Criteria, Rev.2, August 8, 2000.

11 "Procedure WAC 4.01 Acceptance Criteria for Aqueous Waste Sent to Z Area Saltstone Production Facility", WSRC Procedure Manual 1S SRS - Waste Acceptance Criteria, Rev.2, June 19, 1998.

${ }^{12}$ D. T. Hobbs, "Estimated Changes in Supernate Plutonium Concentrations During Washing of Batch 3 Sludge Slurry in Tank 51H," SRT-LWP-2002-00042

${ }^{13}$ C.J. Coleman, "Sodium Peroxide/Sodium Hydroxide Dissolution of Sludge and Glass for Elemental and Anion Analysis (U)", ADS Procedure, ADS-2502, Rev.3.

${ }^{14}$ J.D. Hack, "Updated Nuclear Criticality Safety Analysis Summary Report The S-Area Defense Waste Processing Facility Sludge-Only Operation (U)”, WSRC-RP-94-1132, Rev. 1, December, 1999.

${ }^{15}$ C.J. Coleman, N.E. Bibler, D.M. Ferrara and S.F. Siegwald, "Reaction of Formic and Nitric Acids with Savannah River Site Radioactive HLW Sludge in the DWPF Pretreatment Steps (U)", Nuclear and Hazardous Waste Management-Spectrum 94, pages 737-741, August 1994.

${ }^{16}$ D.C. Koopman and N.M. Askew, "Lack of Segregation of Pu-rich Particles in the DWPF SRAT (U)", SRTATS-2002-00038, Rev.0. 